\title{
Characterization of the Hydrogeology and Water Quality at the Management Systems Evaluation Area Near Princeton, Minnesota, 1991-92
}

By G.N. Delin ${ }^{1}$, M.K. Landon ${ }^{1}$, J.A. Lamb ${ }^{2}$, and J.L. Anderson ${ }^{2}$

U.S. Geological Survey

Water-Resources Investigations Report 94-4149

Prepared in cooperation with the

University of Minnesota Department of Soil Science, the U.S.

Department of Agriculture, Agricultural Research Service, and the Minnesota Pollution Control Agency

Mounds View, Minnesota

1994

${ }^{1}$ U.S. Geological Survey

${ }^{2}$ University of Minnesota, Department of Soil Science 


\section{U.S. DEPARTMENT OF THE INTERIOR \\ Bruce Babbitt, Secretary \\ U.S. GEOLOGICAL SURVEY \\ Gordon P. Eaton, Director}

For additional information write to:

District Chief

U.S. Geological Survey

2280 Woodale Drive

Mounds View, MN 55112
Copies of this report can be purchased from:

U.S. Geological Survey

Earth Science Information Center

Open-File Reports Section

Box 25286, MS 517

Denver Federal Center

Denver, CO 80225 


\section{Contents}

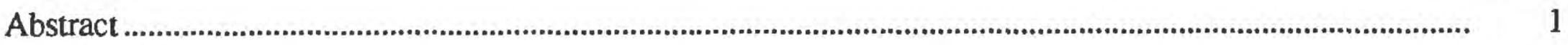

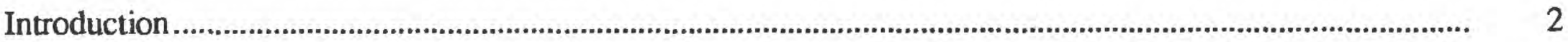

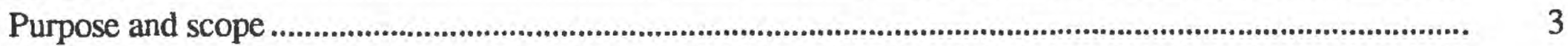

Location of study area ........................................................................................................................... 3

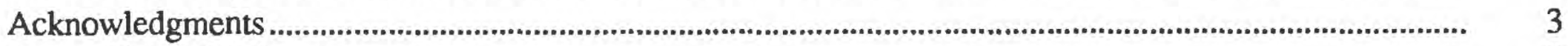

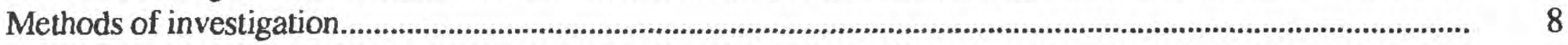

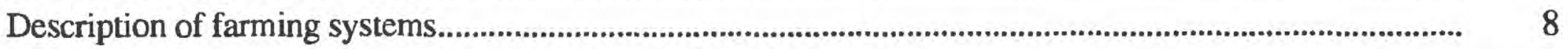

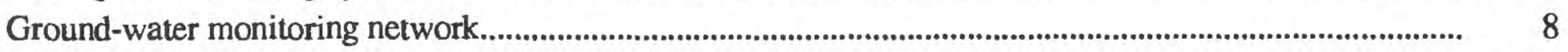

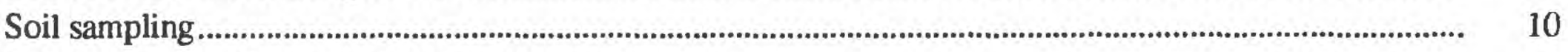

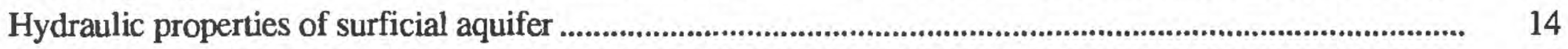

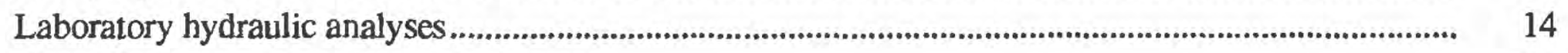

Hazen formula and particle-size analyses.................................................................................... 14

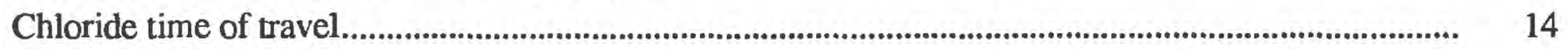

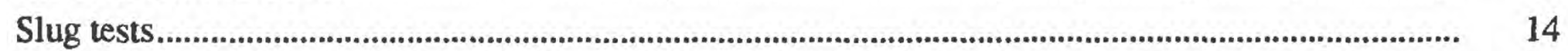

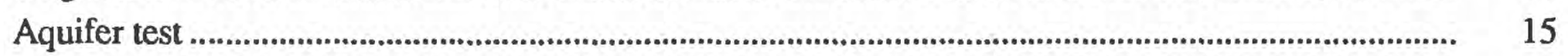

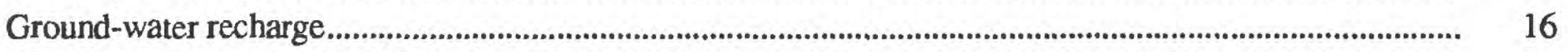

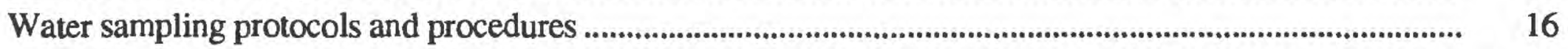

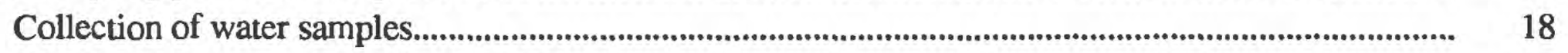

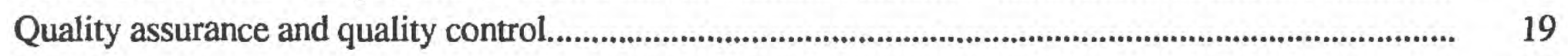

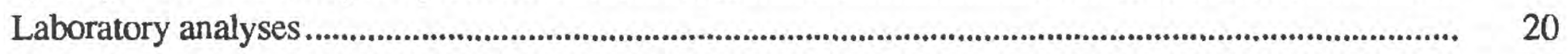

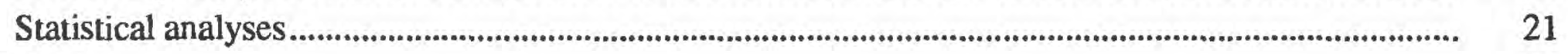

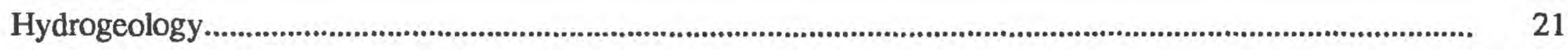

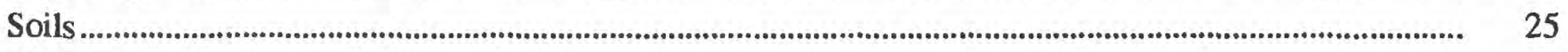

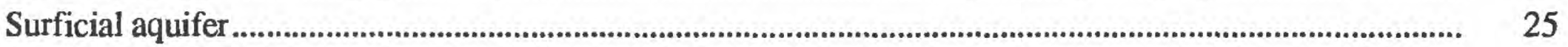

Hydraulic properties of the surficial aquifer............................................................................................ 29

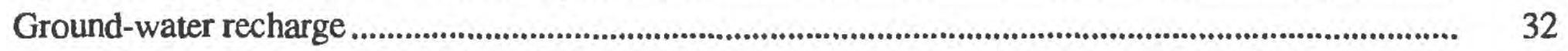

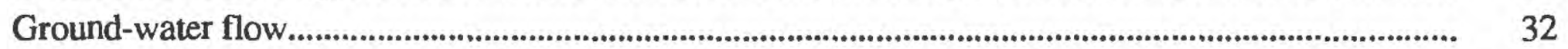

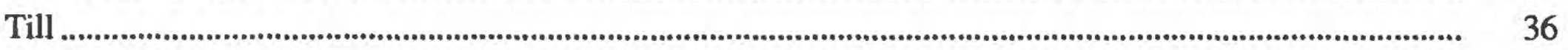

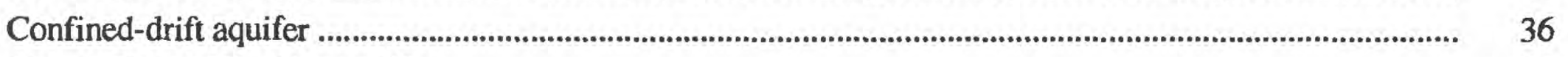

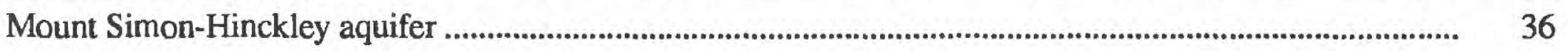

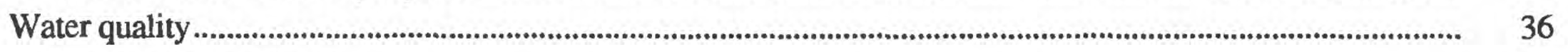

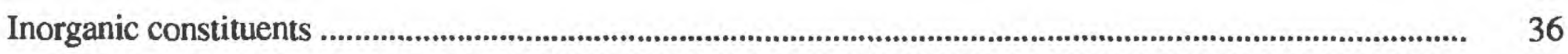

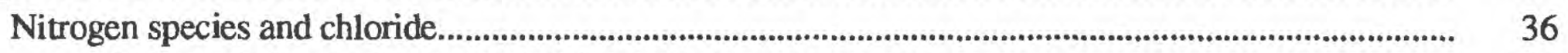

Source of nitrate nitrogen and chloride in the research area...................................................... 41

Comparison to regional ground-water quality .......................................................................... 41

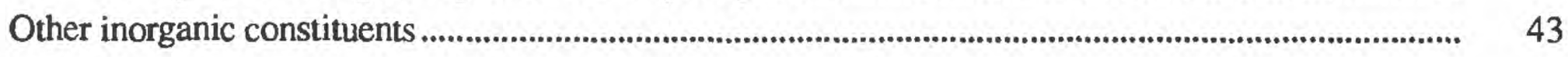

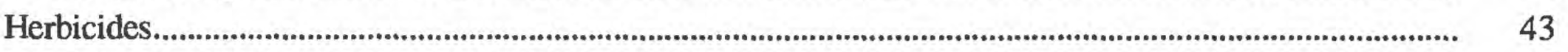

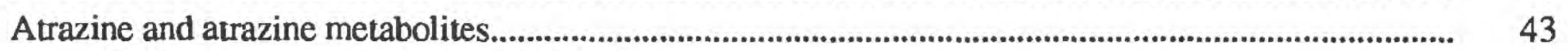

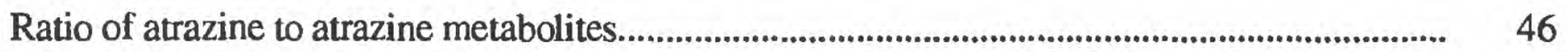

Source of atrazine and atrazine metabolites in the research area.................................................... 46

Comparison to regional ground-water quality ................................................................................. 49

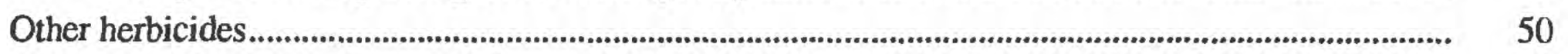

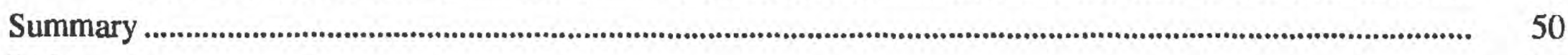

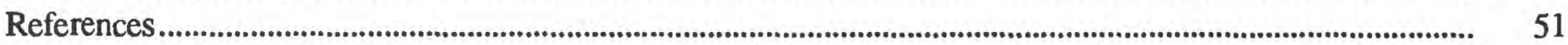




\section{Illustrations}

Figures 1-7c. Maps showing:

1. Location of Management Systems Evaluation Areas in the midwest.

2. Location of the Princeton, Minnesota Management Systems Evaluation

Area in the Anoka Sand Plain.

3. Location of the research area, study area, and watershed encompassing

the Princeton, Minnesota Management Systems Evaluation Area

4. Study area and water-table configuration near the Princeton, Minnesota

Management Systems Evaluation Area, November 1991

5. Land-surface topography at the the Princeton, Minnesota Management Systems Evaluation Area.

6. Layout of the research area at the Princeton, Minnesota Management Systems Evaluation.

7a. Calculated ground-water flow path downgradient of cropped area A at the Princeton, Minnesota Management Systems Evaluation Area, 1991.

7b. Calculated ground-water flow path downgradient of cropped area C at the Princeton, Minnesota Management Systems Evaluation Area, 1991

7c. Calculated ground-water flow path downgradient of cropped area $\mathrm{E}$ at the Princeton, Minnesota Management Systems Evaluation Area, 1991

8. Graph showing water-level hydrograph and recharge calculations for observation well MC28 at the Princeton, Minnesota Management Systems

Evaluation Area, 1991-92.

9. Diagram showing generalized stratigraphic section and hydrogeologic properties at the Princeton, Minnesota Management Systems Evaluation

Area.

10. Hydrogeologic section A-A' through the Princeton, Minnesota Management Systems Evaluation Area.

11. Hydrogeologic section B-B' through the Princeton, Minnesota Management Systems Evaluation Area

12-17. Maps showing:

12. Soils at the Princeton, Minnesota Management Systems Evaluation Area 


\section{Illustrations--Continued}

13. Saturated thickness of the surficial aquifer at the Princeton, Minnesota Management Systems Evaluation Area. October 1991.

14. Water-table configuration at the Princeton, Minnesota Management Systems Evaluation Area, May 1991

15. Water-table configuration at the Princeton, Minnesota Management Systems Evaluation Area, August 1991

16. Configuration of base of surficial aquifer at the Princeton, Minnesota Management Systems Evaluation Area

17. Concentrations of nitrate nitrogen in the study area, April 1991

18. Box plots showing the statistical distribution of selected cations and anions in the study area, April 1991

19. Trilinear diagram showing the chemical character of water in the study area. April 1991......

20. Box plots showing the statistical distribution of selected herbicides and field parameters for the study area, April 1991

21-23. Maps showing concentrations of:

21. Atrazine in the study area, April 1991

22. De-ethylatrazine in the study area, April 1991

23. De-isopropylatrazine in the study area, April 1991

\section{Tables}

1. Description of soil map units at the Princeton, Minnesota Management Systems Evaluation Area

2. Median values of soil texture, organic-carbon content, bulk density, and saturated hydraulic conductivity for the upper 1.5 meters of the unsaturated zone in cropped areas B and D at the Princeton, Minnesota Management Systems Evaluation Area

3. Moisture-retention characteristics for the upper 1.5 meters of the unsaturated zone for cropped areas B and D at the Princeton, Minnesota Management Systems Evaluation Area.

4. Estimated horizontal saturated hydraulic conductivity of the surficial aquifer at the Princeton, Minnesota Management Systems Evaluation Area.

5. Estimated ground-water recharge to the surficial aquifer at the Princeton, Minnesota Management Systems Evaluation Area, 1991-92.

6. Mean concentration of organic matter, $\mathrm{pH}$, and nutrients in soil samples collected during April 1991 at the Princeton, Minnesota Management Systems Evaluation Area. 


\section{Conversion Factors and Abbreviations}

$\begin{array}{lcl}\text { Multiply } & \text { By } & \text { To obtain } \\ \text { meter }\left(\mathrm{m}^{3}\right) & 35.31 & \begin{array}{l}\text { cubic foot } \\ \text { cubic meter per second }\left(\mathrm{m}^{3} / \mathrm{s}\right)\end{array} \\ \text { cubic per } \\ \text { kilometer }(\mathrm{km}) & .2119 & \text { mile } \\ \text { meter }(\mathrm{m}) & .6215 & \text { foot } \\ \text { meter per day }(\mathrm{m} / \mathrm{d}) & 3.281 & \text { foot per day } \\ \text { centimeters }(\mathrm{cm}) & 3.281 & \text { inch } \\ \text { centimeter per second }(\mathrm{cm} / \mathrm{s}) & .3937 & \text { foot per second } \\ \text { hectare }(\text { ha) } & .03281 & \text { acres } \\ \text { kilograms per hectare }(\mathrm{kg} / \mathrm{ha}) & 2.471 & \text { pounds per acre } \\ \text { kilograms per cubic meter }\left(\mathrm{kg} / \mathrm{m}^{3}\right) & 1.1206 & \text { pounds per cubic foot } \\ \text { liter }(\mathrm{L}) & .06243 & \text { gallon } \\ \text { liter per second }(\mathrm{L} / \mathrm{s}) & .2642 & \text { gallon per minute } \\ \text { square kilometer }\left(\mathrm{km}{ }^{2}\right) & 5.85 & \text { square mile } \\ \text { square meter }\left(\mathrm{m}^{2}\right) & .3861 & \text { acres } \\ \text { square meter per day }\left(\mathrm{m}^{2} / \mathrm{d}\right) & 2.47 \times 10^{-4} & \text { square foot } \\ \text { degrees Celsius }\left({ }^{\circ} \mathrm{C}\right) & 10.76 & \text { per day } \\ \text { degrees Fahrenheit }\end{array}$

Sea level: In this report sea level refers to the National Geodetic Vertical Datum of 1929 (NGVD of 1929) - a geodetic datum derived from a general adjustment of the first-order level nets of both the United States and Canada, formerly called Sea Level Datum of 1929.

Use of brand names in this report is for identification purposes only and does not constitute endorsement by the U.S. Geological Survey. 


\title{
CHARACTERIZATION OF THE HYDROGEOLOGY AND WATER QUALITY AT THE MANAGEMENT SYSTEMS EVALUATION AREA NEAR PRINCETON, MINNESOTA, 1991-92
}

\author{
By Geoffrey N. Delin', Matthew K. Landon', John A. Lamb², \\ and James L. Anderson ${ }^{2}$
}

\begin{abstract}
The Management Systems Evaluation Area (MSEA) program is part of a multi-scale, inter-agency initiative to evaluate the effects of agricultural systems on water quality in the midwest corn belt. The Minnesota MSEA project is one of five projects selected to represent the principal hydrogeologic settings and geographic diversity of prevailing management systems in the midwest corn belt. The Minnesota MSEA research area is located in the Anoka Sand Plain about 5 kilometers southwest of Princeton, Minnesota. The water-quality monitoring network within the 65-hectare research area consists of 29 observation wells and 22 multiport wells. Thirteen observation wells also are located outside the research area.

Glacial deposits beneath the research area generally consist of fine to medium sand in the unsaturated zone and coarse to very coarse sand and gravel in the saturated zone. The average depth to the water table is about 3.6 meters below land surface. Ground-water recharge during 1992 was lower (4.9-13.2 centimeters) than during 1991 (11.7-25.7 centimeters) because of reduced precipitation (58.5 centimeters during 1992 and 94.5 centimeters during 1991).

Estimates of saturated horizontal hydraulic conductivity for the surficial aquifer were made using five methods. Results were within about two orders of magnitude and also agree favorably with estimates from a previous study of the Anoka Sand Plain. The smallest hydraulic conductivities were obtained using laboratory analyses $(0.0052$ centimeters per second) and the largest estimate was obtained from results of an aquifer test ( 0.2820 centimeters per second). The estimate of hydraulic conductivity based on the time of travel of chloride $(0.0655$ centimeters per second) is considered most accurate and representative of the surficial aquifer in the research area.

Anthropogenic effects of previous land use were detected in water samples collected during April 1991, prior to implementation of the MSEA farming systems. Concentrations of nitrate nitrogen (nitrate- $\mathrm{N}$ ) in the surficial aquifer equaled or exceeded the U.S. Environmental Protection Agency's recommended maximum contaminant level of 10 milligrams per liter $(\mathrm{mg} / \mathrm{L})$ in 4 of the 7 wells in the research area. The maximum concentration of nitrate-N in ground water from these wells was $23 \mathrm{mg} / \mathrm{L}$ with a median of $10 \mathrm{mg} / \mathrm{L}$. The median concentration of nitrate- $\mathrm{N}$ for these wells exceeded the median in wells located upgradient from the research area $(2.1 \mathrm{mg} / \mathrm{L})$. Similarly, the median concentration of chloride from wells in the research area $(11 \mathrm{mg} / \mathrm{L})$ exceeded the median in upgradient wells $(3.8 \mathrm{mg} / \mathrm{L})$. On-site sources of the elevated nitrate-N include decomposition of alfalfa grown on site during 1981-89, and application of nitrogen fertilizer to corn during 1990 . A likely on-site source of the elevated chloride is application of potassiumchloride fertilizer to crops prior to 1991.
\end{abstract}

Atrazine was detected by gas chromatography mass spectroscopy in 2 of the 7 wells in the research area at concentrations of 0.04 and 0.17 micrograms per liter $(\mu \mathrm{g} / \mathrm{L})$, well below the U.S. Environmental Protection Agency's recommended maximum contaminant level of $3 \mu \mathrm{g} / \mathrm{L}$. The median concentration in these wells was less than the qualitative detection limit of $0.01 \mu \mathrm{g} / \mathrm{L}$. Atrazine metabolite de-ethylatrazine was the most frequently detected herbicide or herbicide metabolite. De-ethylatrazine was detected in 5 of the 7 wells in the research area at concentrations ranging from 0.12 to $0.32 \mu \mathrm{g} / \mathrm{L}$ with a median concentration of $0.14 \mu \mathrm{g} / \mathrm{L}$. Atrazine metabolite de-isopropylatrazine was not detected above the qualitative detection limit of $0.06 \mu \mathrm{g} / \mathrm{L}$. The most likely sources of atrazine are applications prior to the research area during 1990 or from precipitation.

\section{'U.S. Geological Survey}

${ }^{2}$ University of Minnesota, Department of Soil Science 


\section{Introduction}

The Management Systems Evaluation Area (MSEA) program is part of a multi-scale, inter-agency initiative to evaluate the effects of agricultural systems on water quality. Evaluation of the agricultural systems involves management of agricultural practices used to grow crops. These practices include crop selection, crop rotation, selection of the types, timing, and rates of chemical application used to control pests, rates of fertilizer application to enhance crop growth, and crop tillage. The objectives of the MSEA program are to: (1) measure the effects of prevailing and modified agricultural management systems on ground-water and surface-water quality; (2) understand the processes and factors affecting the fate of selected agricultural chemicals; (3) assess the effects of selected agricultural chemicals on local ecosystems; (4) assess the projected benefits to water quality of implementing modified management systems; (5) evaluate the socioeconomic effects of using alternative management systems; and (6) transfer appropriate technology for use by farmers (Soil and Water Conservation Society, 1993). The 5-year MSEA program began in 1990 and is part of the President's Initiative on Water Quality. The midwest corn belt was selected for study because about 60 percent of the Nation's pesticides and nitrogen fertilizers are used in this region (Gianessi and Puffer, 1988). The MSEA program is a collaborative effort between the Agricultural Research Service (ARS) and Cooperative State Research Service (CSRS) branches of the U.S. Department of Agriculture (USDA),

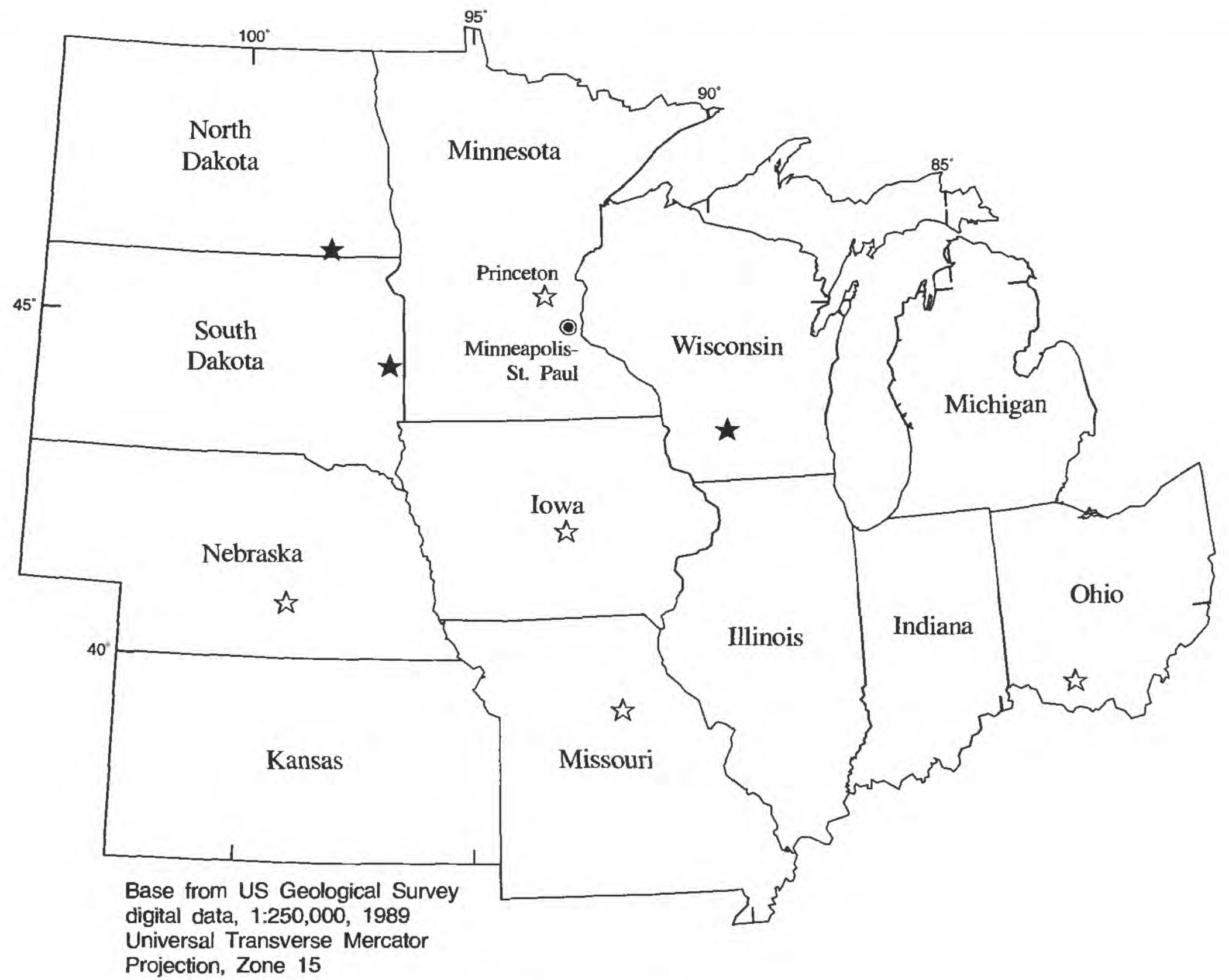

EXPLANATION

is Primary MSEA

Mirıriesota MSEA satellite location

Figure 1.--Location of Management Systems Evaluation Areas (MSEAs) in the midwest. 
the U.S. Geological Survey (USGS), and the U.S. Environmental Protection Agency (USEPA). Research on agricultural practices affecting water quality varied in scale from the laboratory to $50-\mathrm{km}^{2}$ watersheds. Five primary MSEAs (fig. 1) were selected to represent a variety of hydrogeologic settings and the geographic diversity of prevailing farming practices in the region. MSEAs dominated by coarse-grained soils with relatively high water-draining capacity, such as glacial sand and gravel, were in Minnesota, Nebraska, and Ohio. Those dominated by finer-grained soils with relatively low water-draining capacity, such as loess and glacial till, were located in lowa and Missouri. Research on effects of the management systems on ground-water quality was conducted at all five MSEAs, but the effects on surfacewater quality also were a major consideration at the Iowa and Missouri MSEAs.

The Minnesota MSEA has a primary research area near Princeton, Minnesota in the Anoka Sand Plain, an area of glacial outwash covering about $4,400 \mathrm{~km}^{2}$, and satellite locations located near Oakes, North Dakota; Brookings, South Dakota; and Arena, Wisconsin (fig. 2) (Delin and others, 1992; Anderson and others, 1991). Each of these locations were in sand-plain areas considered typical of the northern corn belt region. The interagency research objective of the Minnesota MSEA is to evaluate the effects of a modified farming system on ground-water quality in sand-plain areas with slightly different climatic conditions. The modified farming system used irrigated ridge tillage in a corn-soybean rotation. Nitrogen fertilizer and the herbicides atrazine, alachlor, and metribuzin were applied. Although the modified farming system was evaluated at satellite locations in North Dakota, South Dakota, and Wisconsin, research was concentrated at the primary area near Princeton, Minnesota. The remainder of this report discusses information pertinent only to the Princeton MSEA.

Hydrologic research at the Princeton MSEA was conducted primarily by the USGS in cooperation with the University of Minnesota Department of Soil Science, the USDA-ARS, and the Minnesota Pollution Control Agency (MPCA). Other agencies that conducted research at the Princeton MSEA included the USDA-Soil Conservation Service, the University of Minnesota Department of Agricultural Engineering, the University of Minnesota Department of Geology and Geophysics, and the USEPA.

The primary objectives of research by the USGS at the Princeton MSEA were to: (1) determine the relation of the spatial and temporal distribution of agricultural chemicals in ground water to recharge, topography, and subsurface heterogeneities; and (2) determine the effects of the modified and prevailing farming systems on ground-water quality.

\section{Purpose and Scope}

This report describes the geology, hydraulic properties, and ground-water quality within the glacial materials at the Princeton MSEA. The methods used to collect stratigraphic, hydraulic, and water-quality data are also described. A detailed description of ground- and surface-water quality is presented for a sampling period prior to installation of the MSEA agricultural management systems. This description of water quality is provided as a necessary prerequisite to evaluating the effects of the MSEA management systems on groundwater quality. Geologic logs and water-quality data used to characterize the study area are presented by Delin and others (1994).

\section{Location of Study Area}

The 8.3- $\mathrm{km}^{2}$ study area is located about $5 \mathrm{~km}$ southwest of Princeton, Minnesota and about $80 \mathrm{~km}$ northwest of Minneapolis and St. Paul (fig. 2). The 65-ha research area is located about in the middle of the study area and adjacent to a wetland (figs. 3, 4, and 5).

Topography is undulating in the research area with a maximum change in elevation of $3 \mathrm{~m}$ over a horizontal distance of about $40 \mathrm{~m}$. The area is drained primarily by Battle Brook, a tributary of the St. Francis River that flows into the Mississippi River (figs. 3 and 4). The research area was selected in part because of the reduced potential for previous agricultural-chemical use in the Kunkel State Wildlife Area, and the Sherburne National Wildlife Refuge (fig. 3). Most of the approximately $77.8 \mathrm{~cm}$ of mean annual precipitation (U.S. Department of Commerce, 1961-92) is rainfall during May through September. Mean potential evapotranspiration calculated by the Thornthwaite method is about $61 \mathrm{~cm}$ per year (Baker and others, 1979, p. 8). Mean monthly temperatures vary from about $21^{\circ} \mathrm{C}$ in July to about $-14^{\circ} \mathrm{C}$ in January (Baker and others, 1985, p. 48).

\section{Acknowledgments}

The authors acknowledge Robert H. Dowdy (U.S. Department of Agriculture-Agricultural Research Service), co-principal investigator with the authors. The authors are also grateful to C.P. Regan, J.A. Magner, and other personnel at the Minnesota Pollution Control Agency and to Lifeng Guo, a graduate student at the University of Minnesota, Department of Geology and Geophysics. The authors are grateful to the U.S. Department of Agriculture-Soil Conservation Service for 


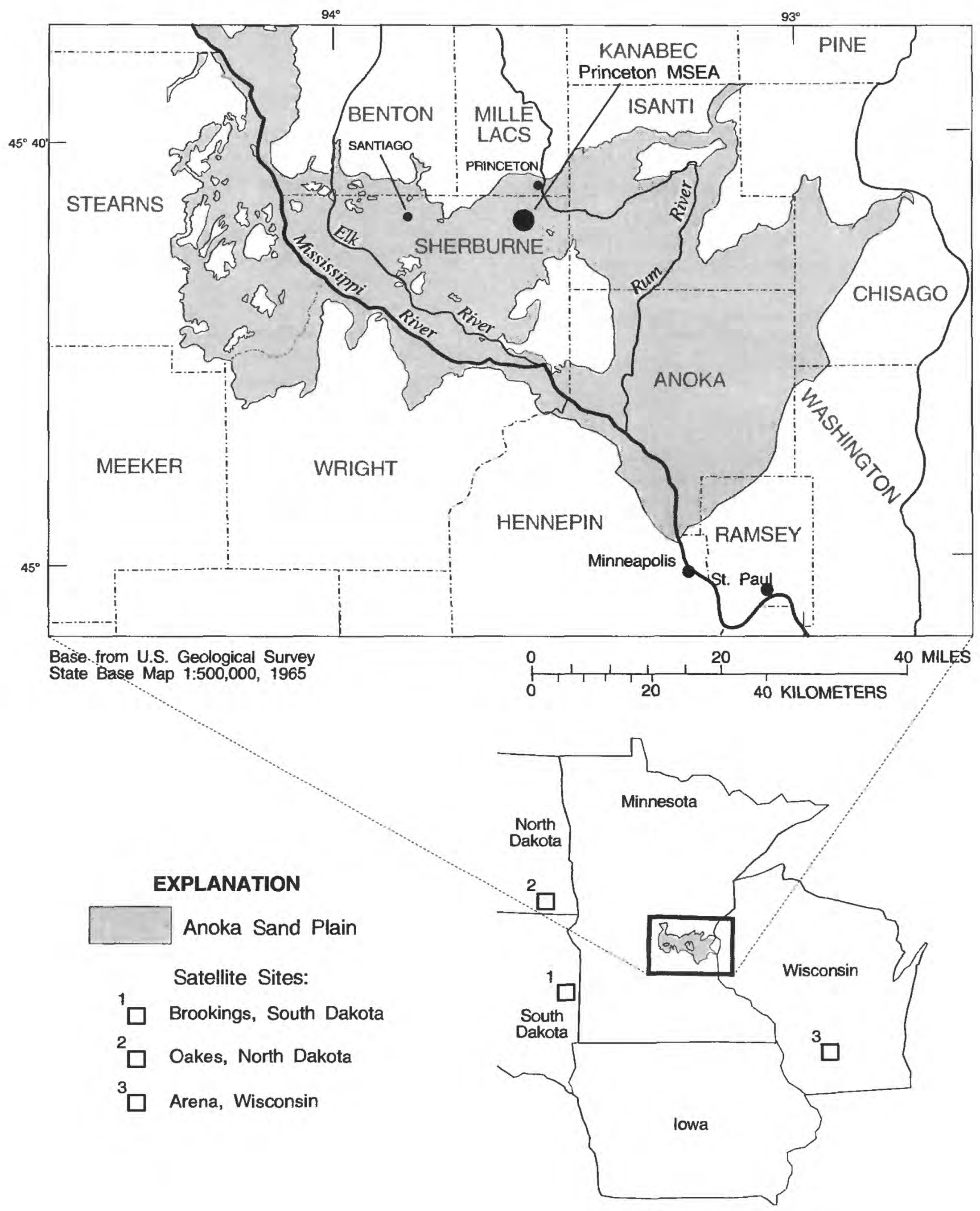

Figure 2.--Location of the Princeton, Minnesota Management Systems Evaluation Area (MSEA) in the Anoka Sand Plain. 


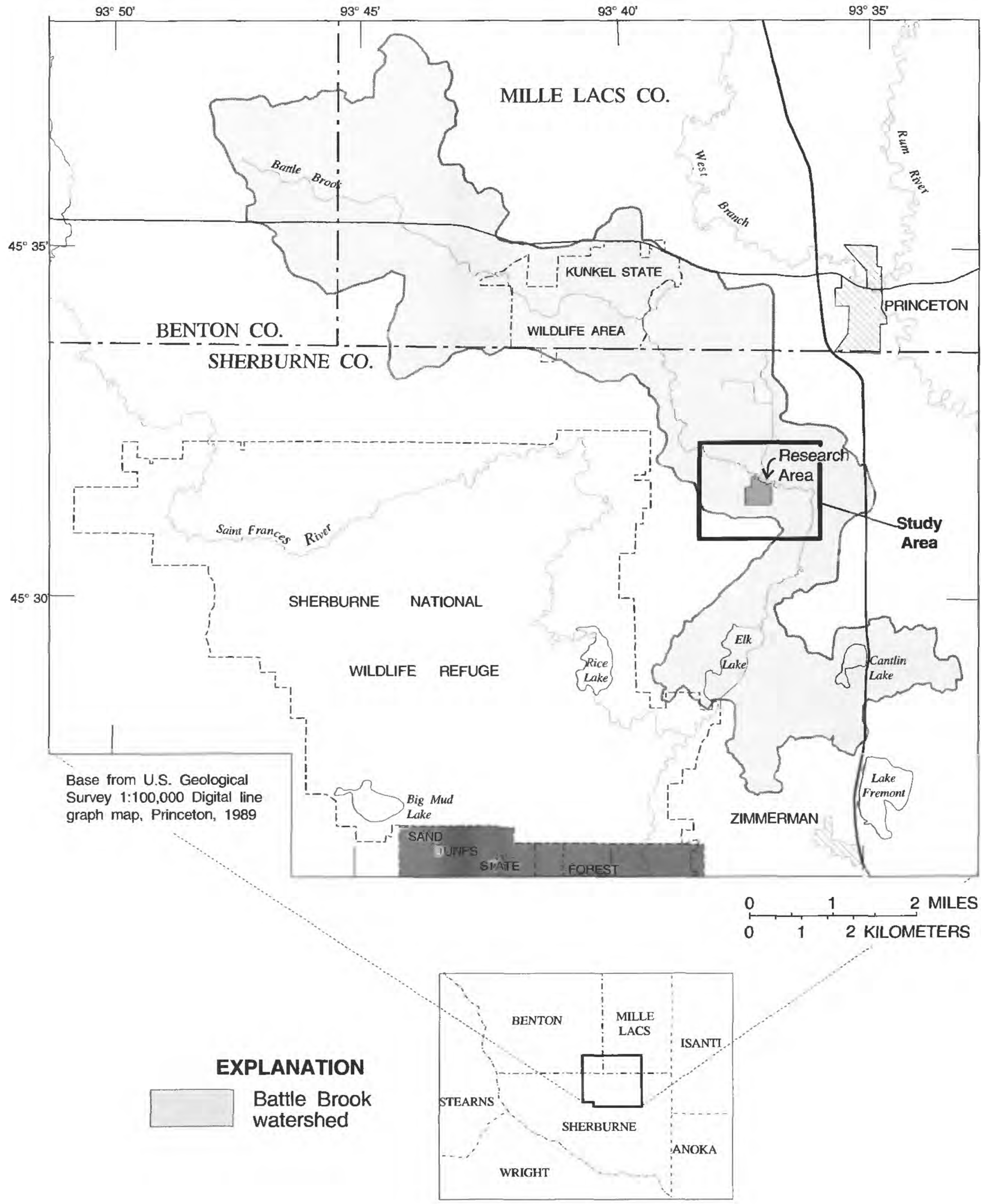

Figure 3.--Location of the research area, study area, and watershed encompassing the Princeton, Minnesota Management Sytstems Evaluation Area. 


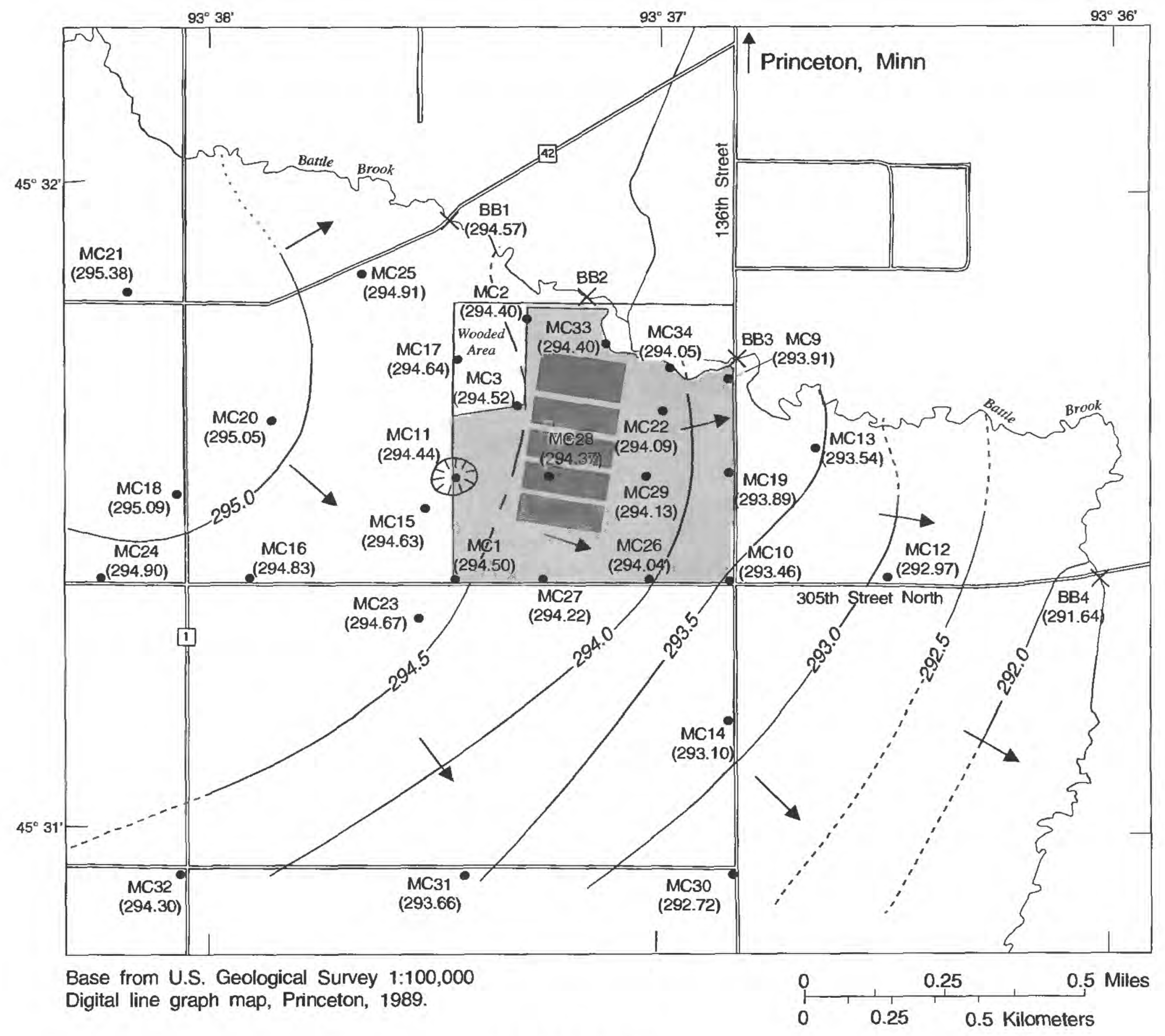

\section{EXPLANATION}

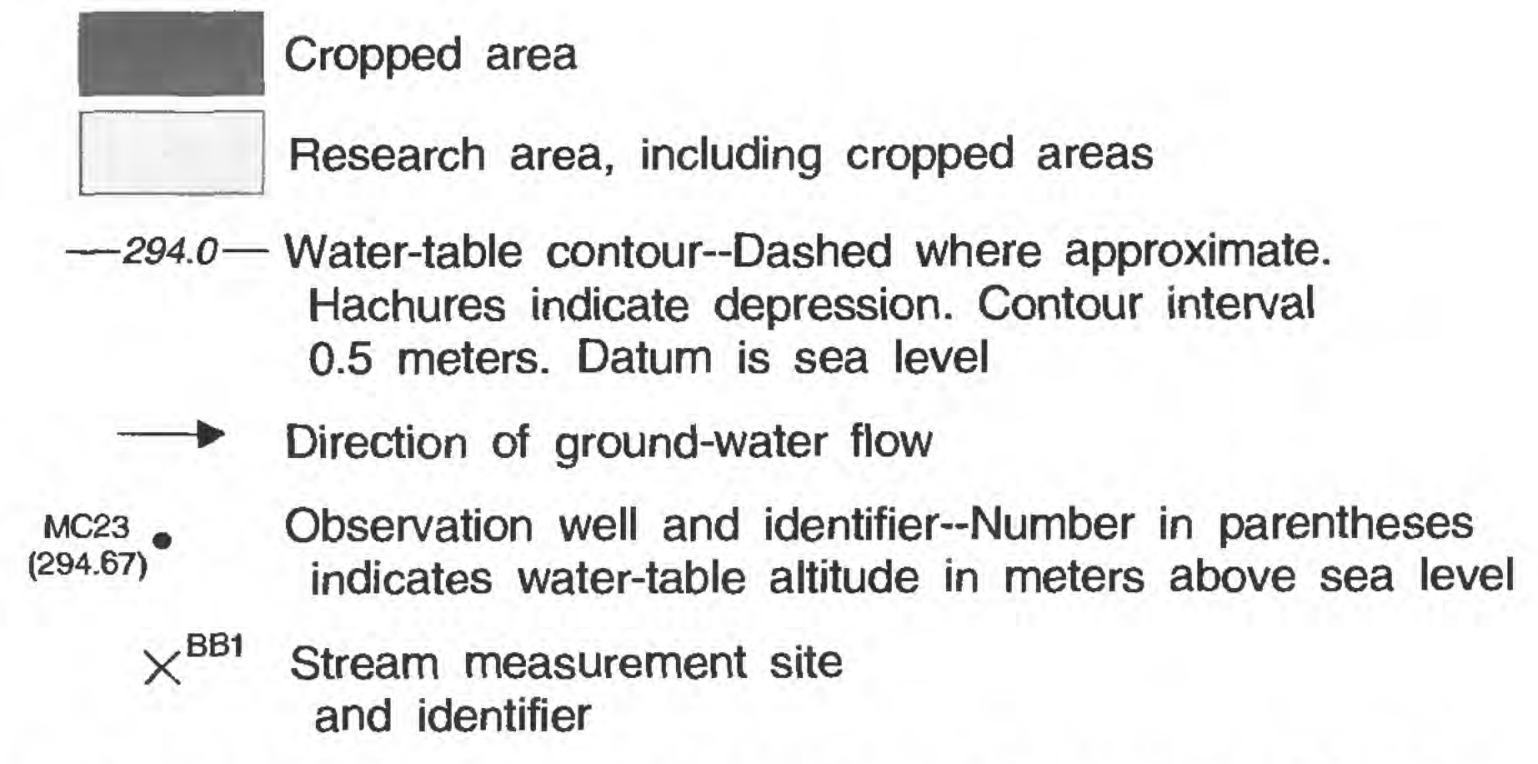

Figure 4.--Study area and water-table configuration near the Princeton, Minnesota Management Systems Evaluation Area, November 1991. 


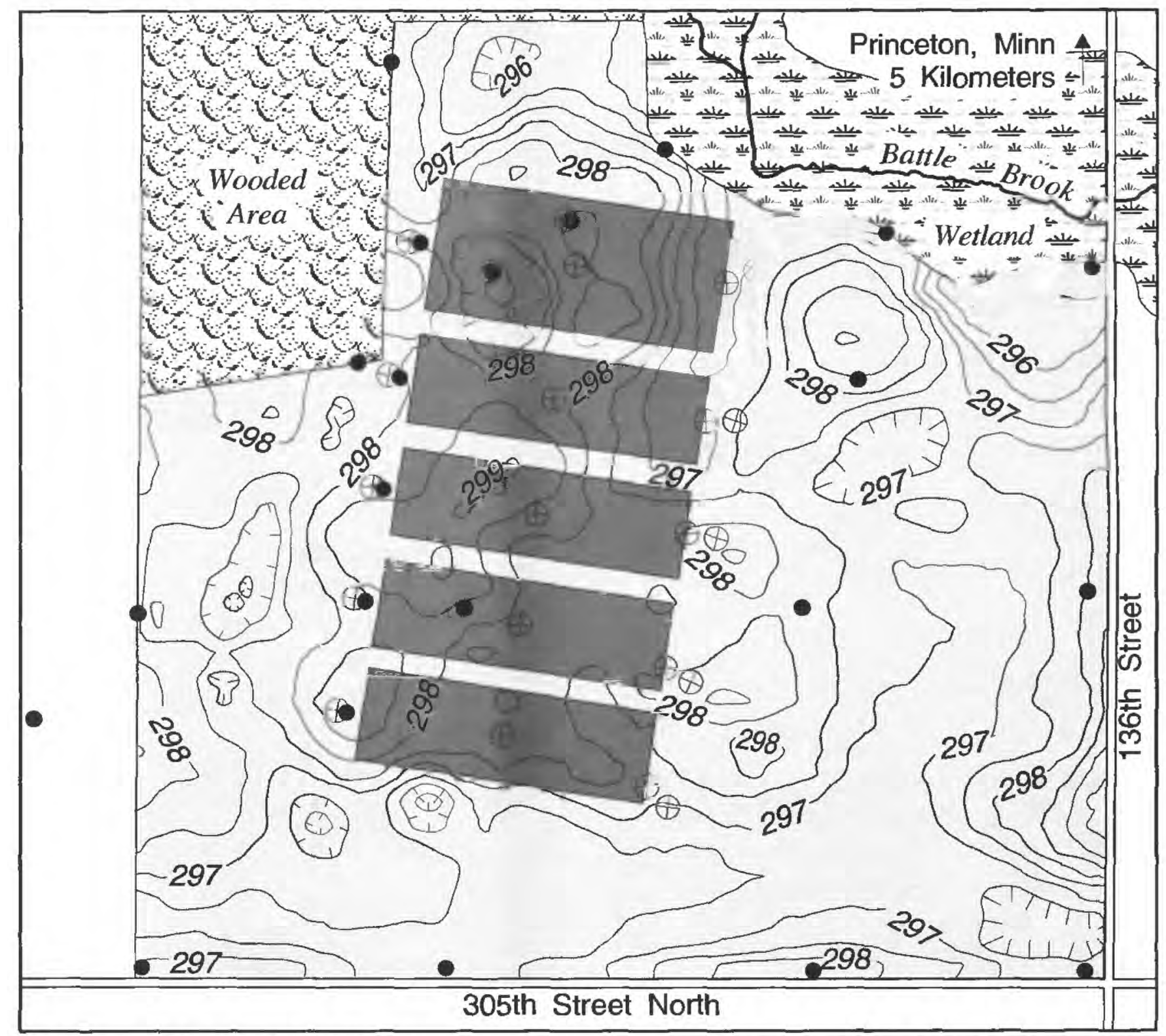

Base from U.S. Geological Survey Princeton 1:24,000 quadrangle, 1982

Topographic data from J.E. Lucius, U.S.

Geological Survey, Lakewood, Colorado

$\begin{array}{cccrl}0 & 250 & 500 & 750 & 1000 \text { FEET } \\ 0 & 100 & 200 & 300 \text { METERS }\end{array}$

\section{EXPLANATION}

\begin{tabular}{|c|c|}
\hline & Cropped area \\
\hline & Research area, including crop \\
\hline-298 & $\begin{array}{l}\text { Topographic contour--Shows a } \\
\text { of land surface. Hachures in } \\
\text { depression. Contour interval } \\
\text { meters. Datum is sea level }\end{array}$ \\
\hline - & Observation well \\
\hline$\Theta$ & Multiport well \\
\hline & $\begin{array}{l}\text { The research area is located } \\
\text { in the northeast quarter of } \\
\text { section } 18 \text {, township } T 35 \mathrm{~N} \text {, } \\
\text { range } \mathrm{R} 26 \mathrm{~W}\end{array}$ \\
\hline
\end{tabular}

Figure 5.--Land-surface topography at the Princeton, Minnesota Management Systems Evaluation Area. 
conducting a detailed soil survey of the research area and to the land owners (Berlinson and Associates) for leasing the land to the University of Minnesota.

\section{Methods of Investigation}

Data used to characterize the research area were primarily collected during 1991 . The following sections describe the methods used to collect the agricultural, geologic, hydrologic, hydraulic, and geochemical information in the research area.

\section{Description of Farming Systems}

Five cropped areas (fig. 6) were established in 1991 to evaluate the effects of selected farming systems on ground-water quality. The effects of these farming systems are described in other reports (Landon and others, in press). A brief description of the farming systems is provided in this report for reference.

The 1.8- to 2.7-ha cropped areas were oriented parallel to the predominant ground-water flow direction (fig. 4) based on water-level data collected during October 1990 through March 1991. This orientation was preferred to minimize the mixing of leachates reaching the water table from adjacent cropped areas. The cropped areas were separated by non-cropped areas that were about $25 \mathrm{~m}$ wide.

The cropped areas were used to evaluate three farming systems (Anderson and others, 1991). The primary farming system is a corn-soybean annual rotation under ridge (conservation) tillage, split nitrogen $(\mathrm{N})$ application (multiple small applications of $\mathrm{N}$ during the growing season rather than one large application), $\mathrm{N}$ credit for legumes (reduction in nitrogen needed to obtain optimum corn growth based on mineralization of nitrogen from soybeans), and banding of herbicides (application only over row and amounting to one-third of the broadcast application amount). The primary comparison farming system is a sweet corn-potato annual rotation with conventional full-width (disk or chisel) tillage and split$\mathrm{N}$ application, banding of herbicides for sweet corn, broadcast application of herbicides for potatoes, with a cover crop after harvest for erosion control. A second comparison farming system is field corn in consecutive years (continuous corn) under conventional full-width tillage, split-N application and broadcast application of herbicides. A buffer area around and between the cropped areas (fig. 6) was planted with a mixture of timothy and smooth brome grass. Agricultural chemicals were not applied in the buffer area. The research area was planted in alfalfa during 1981-89 and in corn during 1990, prior to the implementation of the MSEA farming systems in spring 1991. Agricultural chemicals likely were not applied to the alfalfa during 1981-89. No herbicides were applied on the corn grown during 1990 according to previous land use records.

A linear-move irrigation system was used as necessary to supplement rainfall (fig. 6). The irrigation well was completed in a confined sand and gravel aquifer that is hydraulically separated from the surficial aquifer by a confining layer of clayey till. The well was completed in this confined aquifer so that the hydraulic effects of pumping would be eliminated or minimized near the cropped areas.

\section{Ground-Water Monitoring Network}

The ground-water monitoring network within and immediately surrounding the research area consisted of 29 observation wells and 22 multiport wells (MPORTs) (fig. 6). Thirteen observation wells were also located outside the research area (fig. 4). The observation wells within the research area were constructed of $5.1-\mathrm{cm}$ inside-diameter (i.d.) galvanized-steel or polyvinylchloride (PVC) casing with 15 - or 60 -cm long stainlesssteel screens. The observation wells located outside the research area were constructed of $5.1-\mathrm{cm}$ i.d. galvanizedsteel casing with 60 - or 150 -cm-long stainless-steel screens. All but four of the observation wells in the research area were screened in the upper meter of the saturated zone, with the remaining four wells installed 7 to $14 \mathrm{~m}$ below the water table. The observation wells were installed through the annulus of $10.2-\mathrm{cm}$ i.d. hollowstem augers. The augers were then removed and the natural formation below the water table was allowed to collapse around the casing. Above the water table, a mixture of bentonite and native material was used to backfill the annulus to prevent the vertical movement of water and agricultural chemicals down the borehole.

Water levels were measured monthly in all observation wells using an electronic or a steel tape and were also measured continuously in several observation wells using shaft encoders connected to dataloggers. The observation wells were sampled during April 1991 to determine background concentrations of agricultural chemicals, prior to implementation of the MSEA farming systems.

Each MPORT consisted of six, 0.6-cm i.d. stainlesssteel tubes housed in a 5.1-cm i.d. PVC casing; each tube had a 3-cm long screened interval (port) which was external to the PVC casing. The sampling ports were installed at $50 \mathrm{~cm}$ intervals with the uppermost port $50 \mathrm{~cm}$ above the water table at the time of installation, to allow sample collection if the water table rose. The MPORTs were installed through the annulus of 10.2 -cm i.d. hollowstem augers. The augers were then removed and the 


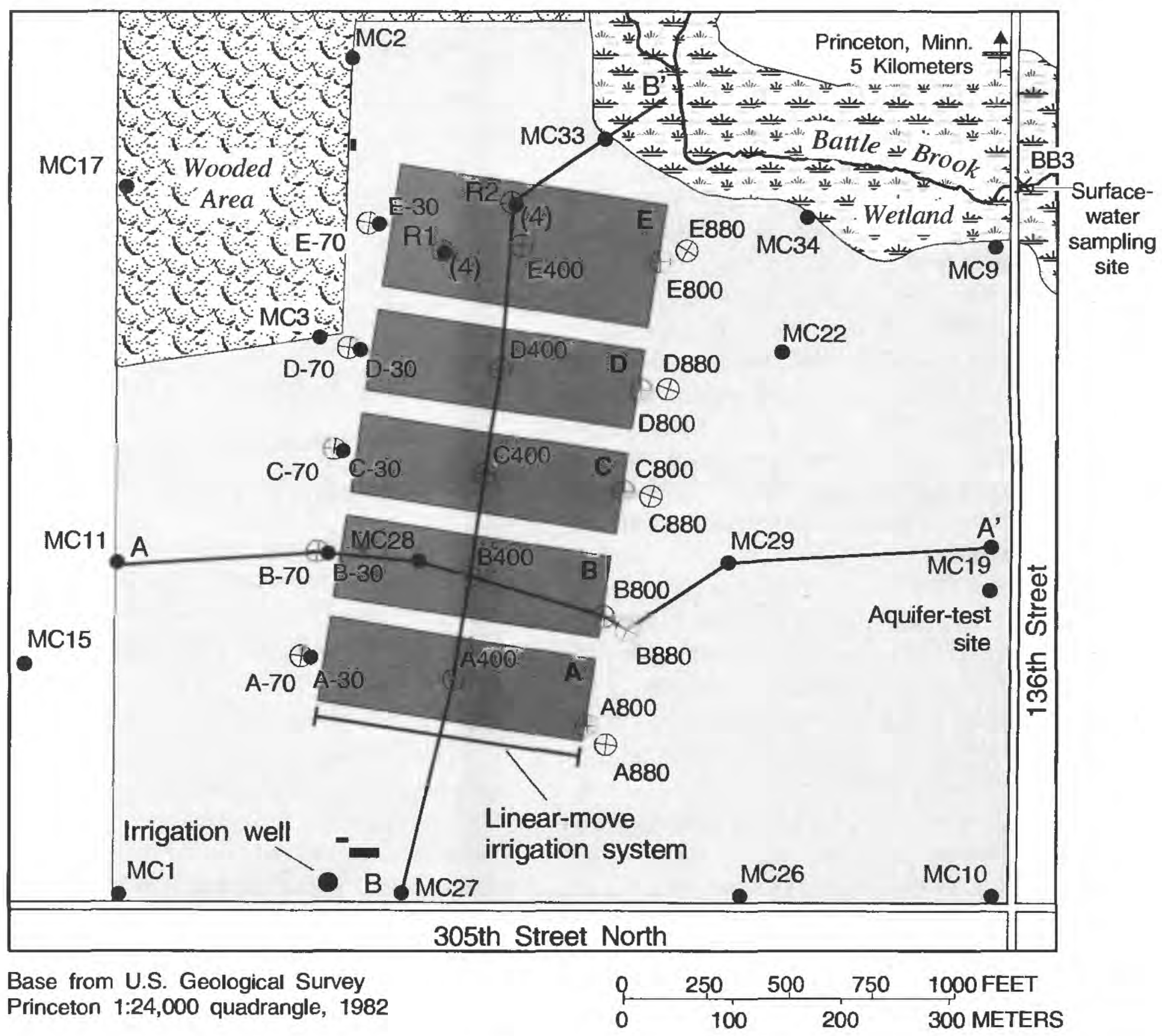

\section{EXPLANATION}

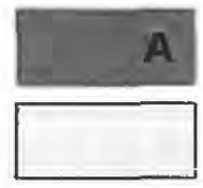

Cropped area and identifier

Research area, including cropped areas

A $-A^{\prime}$ Line of Section

R1 Observation well and identifier, number

(4) in parentheses indicates number

of wells at site

$\oplus_{\text {A880 }}$ Multiport well and identifier

- Building

The research area is located in the northeast quarter of section 18 , township $\mathrm{T} 35 \mathrm{~N}$, range $\mathrm{R} 26 \mathrm{~W}$

Figure 6.--Layout of the research area at the Princeton, Minnesota, Management Systems Evaluation Area. 
natural formation was allowed to collapse around the MPORT. The MPORTs were used to collect water samples to evaluate ground-water quality and to measure water levels monthly to supplement observation-well data.

The MPORTs were located $21 \mathrm{~m}$ upgradient $(-70$ series), in the middle ( 400 series), at the downgradient edge ( 800 series), and $24 \mathrm{~m}$ downgradient of each cropped area (880 series) (fig. 6). Each of the series prefixes corresponds to the distance in feet from the upgradient (west end) of the field; the 400-series MPORTs, for example, were located 400 feet east of the upgradient end of the field. The -70-series MPORTs were located such that the sampled water would be unaffected by MSEA agricultural activities. The -70 -series and $400-$ series MPORTs were located equidistant from the northern and southern edges of each cropped area (fig. 6). The 800-series MPORTs were located on the groundwater-flow line passing beneath the 400 -series MPORTs. The 880-series MPORTs also were located on this same ground-water-flow line, but $24 \mathrm{~m}$ downgradient of the 800 -series MPORTs (figs. 7a, 7b, and 7c). This $24 \mathrm{~m}$ distance was slightly less than the average distance ground water traveled during $1991(28 \mathrm{~m})$.

The ground-water-flow lines used in locating the 880series MPORTs were calculated using 9 synoptic sets of water-level measurements collected during 1991 and using equations (1) and (2). The water-level measurements were used to identify the direction and magnitude of the horizontal hydraulic gradient (change in hydraulic head divided by horizontal distance along a flow line) at the 800-series MPORTs (figs. 7a, 7b, and 7c). The ground-water velocity along each flow line was calculated for each measurement period using the following form of Darcy's Law:

$$
V=K i / \phi
$$

where,

$$
\begin{aligned}
& \mathrm{V}=\text { the ground-water velocity }[\mathrm{L} / \mathrm{T}](\mathrm{m} / \mathrm{d}), \\
& \mathrm{K}=\text { the saturated horizontal hydraulic conductivity } \\
& \\
& {[\mathrm{L} / \mathrm{T}](\mathrm{cm} / \mathrm{s}),} \\
& \mathrm{i}=\text { the hydraulic gradient at the } 800 \text {-series MPORT } \\
& \\
& {[\mathrm{L} / \mathrm{L}](\mathrm{m} / \mathrm{m}) \text {, and }} \\
& \phi=\text { the aquifer porosity [dimensionless]. }
\end{aligned}
$$

A value of $0.035 \mathrm{~cm} / \mathrm{s}$ was used for the hydraulic conductivity and a value of 0.40 was used for the porosity. The water-table configuration determined during each of the nine measurement periods was assumed to be representative of ground-water-flow conditions for half of the time from the previous synoptic measurement to the following synoptic measurement. Thus, the 1991 ground-water-flow lines were divided into nine time periods of unequal length; the length of each time period was dependent upon the length of time between preceding and succeeding water-level measurements (figs. 7a, 7b, and 7c). The distance ground water traveled along a flow line during each time period was calculated using the following equation:

$$
\mathrm{D}=\mathrm{Vt}
$$

where,

$$
\begin{aligned}
& D=\text { the distance traveled during the period }[\mathrm{L}](\mathrm{m}), \\
& \mathrm{V}=\text { the ground-water velocity }[\mathrm{L} / \mathrm{T}](\mathrm{m} / \mathrm{d}) \text {, and } \\
& \mathrm{t}=\text { the length of the time period }[\mathrm{T}] \text { (day). }
\end{aligned}
$$

The distance traveled and direction of ground-water flow for each time period was summed to calculate a resultant ground-water-flow vector for 1991 from each 800-series MPORT. The 880-series MPORTs were located along this resultant ground-water-flow vector (figs. $7 \mathrm{a}, 7 \mathrm{~b}$, and 7c).

Cores through the unsaturated zone were collected and a geologic log was prepared for each test hole drilled in the research area (Delin and others, in press). The soil cores were collected in 5.1-cm outside diameter (o.d.), 1.5 -m long polycarbonate tubes using a core barrel design developed by Zapico and others (1987). The core barrel was equipped with an interior piston attached to a wireline that resulted in core recoveries of about 70-80 percent in the unsaturated zone and 0-60 percent below the water table.

\section{Soil Sampling}

Results of a detailed soil survey conducted during 1990 by the USDA-Soil Conservation Service (Tom Jackson, written commun., 1991) were used to characterize soil texture in the research area. In addition, soil samples were collected to determine the concentrations of herbicide and nitrate within the soils. The cores were collected and analyzed according to protocols established by the MSEA quality-assurance and quality-control committee (Jerry Hatfield, USDA-ARS, Ames, Iowa, written commun., 1990). Two soil cores were collected from within each cropped area during April 1991. The soil cores were collected in $2.5-\mathrm{cm}$ i.d. polycarbonate tubes to a minimum depth of $30 \mathrm{~cm}$ below land surface. The soil samples were maintained at $-20^{\circ} \mathrm{C}$ in a plastic bag prior to shipment to the USDA National Soil Tilth Laboratory in Ames, Iowa. The soil samples were analyzed for concentrations of nitrate- $\mathrm{N}$ and selected pesticides using a robotic extraction procedure (W.C. Koskinen, USDAARS, St. Paul, Minnesota, written commun, 1990.). 


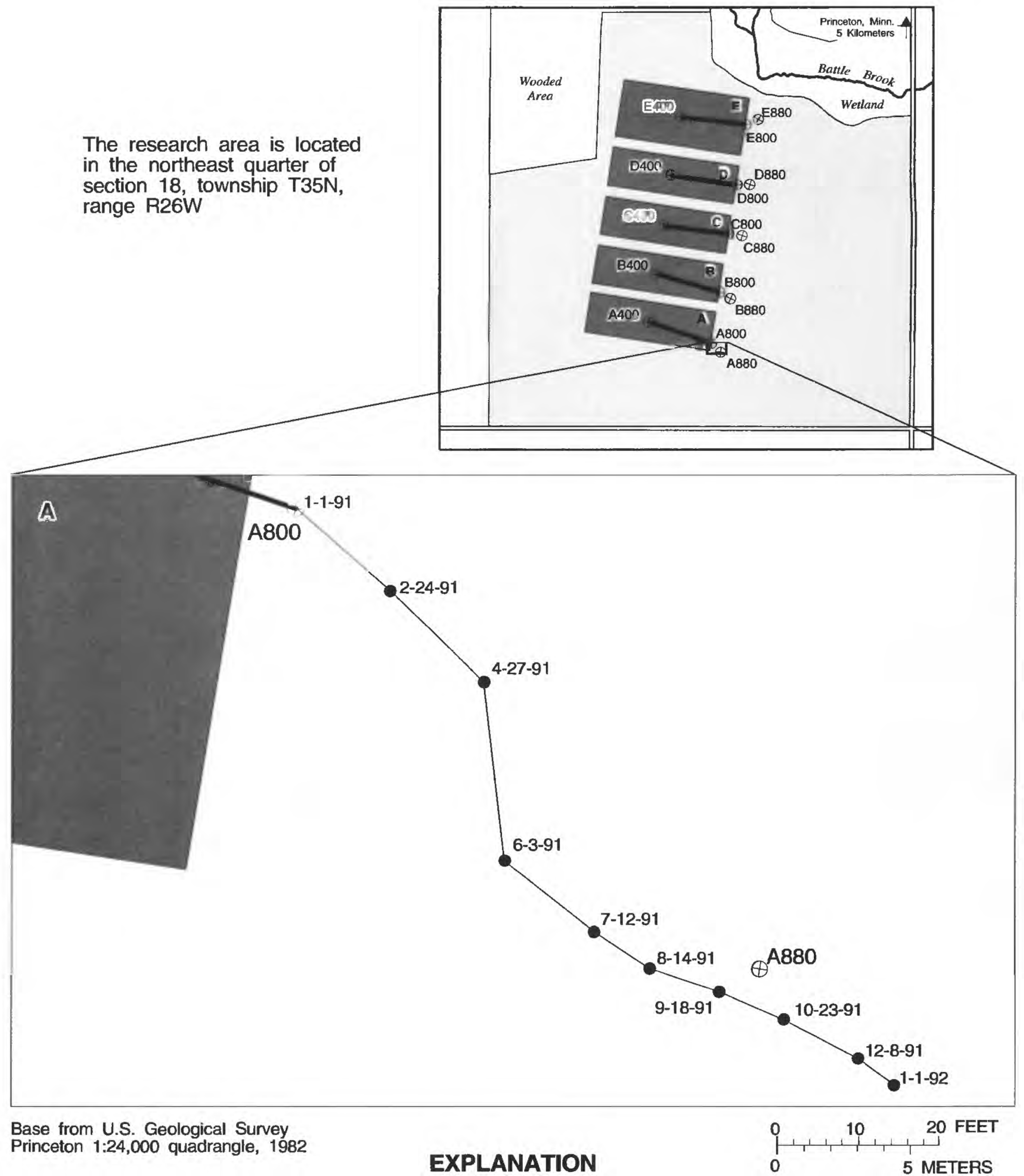

A Cropped area and identifier

Reference line between multiport in middle of cropped area and multiport on downgradient edge of cropped area Calculated 1991 ground-water-flow path

1-1-91 Location of water particle along 1991 flow path on specified date

$\oplus^{A 880}$ Multiport well and identifier

Figure 7a.--Calculated ground-water flow path downgradient of cropped area A at the Princeton, Minnesota Management Systems Evaluation Area, 1991. 
The research area is located in the northeast quarter of section 18 , township T35N, range $\mathrm{R} 26 \mathrm{~W}$

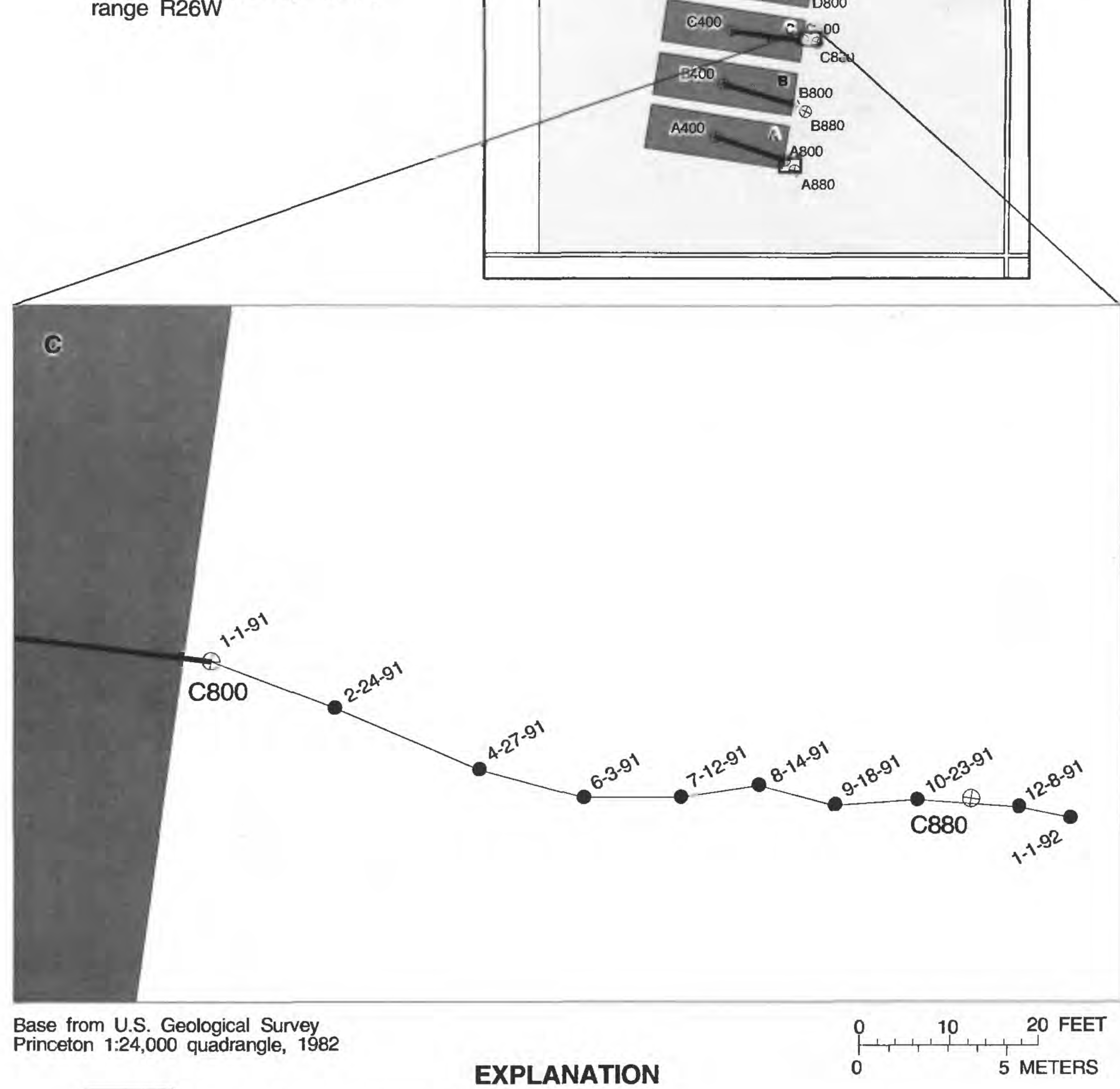

C Cropped area and identifier

Reference line between multiport in middle of cropped area and multiport on downgradient edge of cropped area

1-1-91 Location of water particle Calculated 1991 ground-water-flow path along 1991 flow path on specified date

$\oplus^{\text {C880 Multiport well and identifier }}$

Figure 7b.--Calculated ground-water flow path downgradient of cropped area C at the Princeton, Minnesota Management Systems Evaluation Area, 1991. 


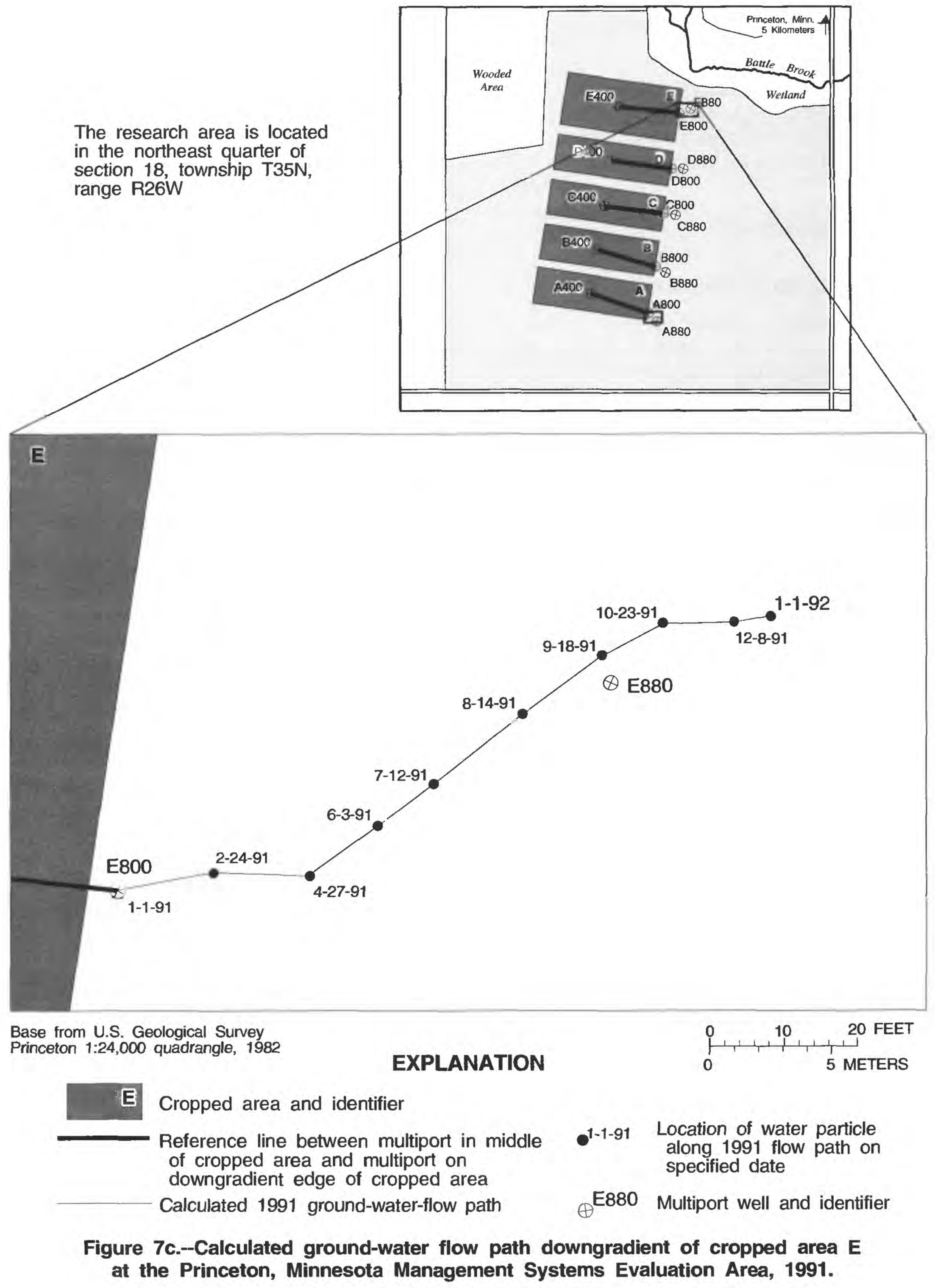




\section{Hydraulic Properties of Surficial Aquifer}

Saturated horizontal hydraulic conductivity of the surficial aquifer was estimated based on laboratory hydraulic analyses, the Hazen formula and particle-size analyses, the time of travel of chloride between MPORT A800 and MPORT A880, slug-tests, and an aquifer test. A general description of the procedures used in each method are discussed below.

\section{Laboratory Hydraulic Analyses}

Laboratory determination of saturated hydraulic conductivity used undisturbed soil cores. The samples were obtained by pushing a 5 -cm-diameter by $8-\mathrm{cm}$-long thin-wall steel tube into the walls in the upper $2 \mathrm{~m}$ of the unsaturated zone of trenches at the R1 and R2 sites (figs. 5 and 6). The R1 site is representative of lowland areas and the $R 2$ site is representative of upland areas within the research area. Three samples also were collected between the 2 to $4 \mathrm{~m}$ depths at R2. Saturated hydraulic conductivities were measured in a triaxial system with a constant-flow method (Olsen and others, 1988 and 1991.

\section{Hazen Formula and Particle-Size Analyses}

Results of particle-size analyses have proven useful in estimating the saturated horizontal hydraulic conductivity for soils in the fine sand to gravel range to within an order of magnitude using the Hazen formula (Freeze and Cherry, 1979, p. 350) as follows:

$$
K=C\left(D_{10}\right)^{2}
$$

where,

$\mathrm{K}=$ the saturated horizontal hydraulic conductivity $[\mathrm{L} / \mathrm{T}](\mathrm{cm} / \mathrm{s})$,

$\mathrm{C}=\mathrm{a}$ constant between 1.0 and 1.5 ; for $\mathrm{K}$ in $\mathrm{cm} / \mathrm{s}$ and $\mathrm{D}_{10}$ in millimeters the constant is equal to 1.0 , and

$D_{10}=$ the effective grain diameter below which 10 percent of the sample is finer $[\mathrm{L}](\mathrm{mm})$.

Samples used in the particle-size analyses were obtained by pushing a $2.5-\mathrm{cm}$-diameter by $5-\mathrm{cm}-$ long stainless-steel sampling tube into the walls of trenches at the R1 and R2 sites (fig. 6). The samples were collected from the upper $2 \mathrm{~m}$ of the unsaturated zone at both sites. Particle-size analyses were conducted using standard American Society for Testing and Materials (ASTM) methods (Gee and Bauder, 1986).

\section{Chloride Time of Travel}

An estimate of the saturated hydraulic conductivity was made based on the transport of chloride from MPORT A800 to MPORT A880 (about 24 m, figs. 7a) during 1991 through 1992. Chloride was used as a tracer of water recharged through the MSEA cropped areas and is conservative (Landon and others, in press). The source of chloride in ground water was potassium-chloride fertilizer applied for crop growth. Cropped area A was selected for this analysis because the application rate of potassium-chloride fertilizer during April 1991 (504 $\mathrm{kg} / \mathrm{ha}$ ) was greater than the rate of application on the other cropped areas $(112 \mathrm{~kg} / \mathrm{ha})$. The estimate of hydraulic conductivity was made using the following form of Darcy's Law:

$$
K=\frac{d \phi}{i t}
$$

where,

$$
\begin{aligned}
& \mathrm{K}=\text { the saturated horizontal hydraulic conductivity } \\
& {[\mathrm{L} / \mathrm{T}](\mathrm{cm} / \mathrm{s}),}
\end{aligned}
$$

Several components of equation 4 were known. The distance (d) between MPORTs A800 and A880 was $24 \mathrm{~m}$ (fig. 7a). Based on particle-size and bulk-density analyses, the median porosity $(\phi)$ of the surficial aquifer was estimated at 0.40 . Based on water-levels measured monthly, the hydraulic gradient (i) between MPORTs $\mathrm{A} 800$ and $\mathrm{A} 880$ for the period of interest was $1.05 \times 10^{-3}$. Therefore, only the time ( $t$ ) for chloride to travel through the saturated zone between MPORTs A800 and A880 needed to be estimated to calculate hydraulic conductivity.

\section{Slug Tests}

Forty-seven slug tests were conducted at 13 observation wells completed in the upper meter of the saturated zone. Five of the wells had $15-\mathrm{cm}$-long stainless-steel screens and eight of the wells had $60-\mathrm{cm}$ long screens. Four additional slug tests were conducted at wells MC33 and MC34 (fig. 6), which were completed in sandy peat and had $90-\mathrm{cm}$-long screens. Each well was fully developed using the surge method prior to 
conducting the tests. The slug-test procedure consisted of rapidly adding 3.8 liters of water to the well. After the water level recovered to pre-test conditions, typically in one minute or less, one to five additional slug tests were conducted on each well. Water-level responses were measured every 0.25 seconds using a pressure transducer connected to a datalogger. The data were analyzed using the method of Bouwer and Rice (1976) and Bouwer (1989) as follows:

$$
K=\frac{r_{c}^{2} \ln \left(\frac{R_{e}}{r_{w}}\right)}{2 L_{e}} \frac{1}{t} \ln \left(\frac{y_{0}}{y_{t}}\right)
$$

where,

$\mathrm{K}$ =the saturated horizontal hydraulic conductivity $[\mathrm{L} / \mathrm{T}](\mathrm{m} / \mathrm{d})$,

$r_{c}=$ the inside radius of the well screen [L] $(m)$,

$R_{e}=$ the effective radius of the well over which the head loss $y_{t}$ is dissipated [L] (m),

$r_{w}=$ the radial distance between the undisturbed aquifer and the well center [L] (m),

$L_{e}=$ the length of the well screen $[L](m)$,

$\mathrm{t}=$ the time since the test began [T] (day),

$y_{o}=$ the head in the well at time $=0[\mathrm{~L}](\mathrm{m})$, and

$y_{t}=$ the head in the well at time $=t[L](m)$.

For the partially penetrating wells in the research area, the dimensionless ratio $\ln \left(R_{e} / r_{w}\right)$ was calculated using the following equation of Bouwer (1989):

$$
\ln \left(\frac{R_{e}}{r_{w}}\right)=\left(\frac{1.1}{\ln \left(\frac{L_{w}}{r_{w}}\right)}+\frac{A+B \ln \frac{\left(H-L_{w}\right)}{r_{w}}}{\frac{L_{e}}{r_{w}}}\right)^{-1}
$$

where,

$$
\begin{aligned}
& \begin{array}{c}
A, B=\text { parameters calculated as a function of } L_{\mathrm{e}} / r_{w} \\
\text { [dimensionless], } \\
H=\text { the saturated thickness of the aquifer }[\mathrm{L}](\mathrm{m}) \text {, and } \\
\mathrm{L}_{w}=\text { the thickness of the aquifer from the water table } \\
\text { to the base of the screen }[\mathrm{L}](\mathrm{m}) .
\end{array}
\end{aligned}
$$

A semi-logarithmic plot of head versus time was generated for each slug test to determine values of $t, y_{0}$, and $y_{t}$. Because each observation well was fully developed, an $r_{w}$ value of $8.9 \mathrm{~cm}$ was used which corresponds to the radial distance from the center of the well to the limit of the zone that was disturbed by the hollow-stem augers and subsequently developed. A value of $5.3 \mathrm{~cm}$ was used for $r_{c}$ which corresponds to the total free-water surface in the well and the developed sand around the well, calculated using an equation presented by Bouwer (1989, p. 305).

\section{Aquifer Test}

An aquifer test was conducted using a centrifugal pump installed in a well located about $32 \mathrm{~m}$ south of well MC19 (fig. 6). The purpose of the test was to estimate the horizontal saturated hydraulic conductivity of the surficial aquifer. The saturated thickness of the aquifer was about $6 \mathrm{~m}$ in the vicinity of the well. The pumped well was constructed of 8-cm-diameter-galvanized-steel casing with a stainless-steel screen completed through about 25 percent of the aquifer, between 0.74 and $2.24 \mathrm{~m}$ below the water table. Water levels in five observation wells were made during the test. Well MC19 was constructed of $5.1-\mathrm{cm}$ diameter galvanized steel casing with a stainless-steel screen completed through about 10 percent of the aquifer, between about 0.2 and $0.8 \mathrm{~m}$ below the water table. The remaining four wells were constructed of 5.1-cm-diameter-galvanized-steel casing with a stainless-steel screen completed through about 15 percent of the aquifer, between the water table and about $2.6 \mathrm{~m}$ below the water table. The observation wells were located between 3.1 and $6.7 \mathrm{~m}$ radially from the pumped well.

Data were collected according to the standards for aquifer-test data collectionand analysis (Stallman, 1971). The well was pumped for 840 minutes at a rate that varied between 1.26 and $1.89 \mathrm{~L} / \mathrm{s}$, with an average pumping rate of about $1.6 \mathrm{~L} / \mathrm{s}$. The well discharge was most variable within the first 100 minutes of the test when it exceeded 10 percent of the average discharge on two occasions. Throughout most of the test, however, the discharge was within 10 percent of the average rate of $1.6 \mathrm{~L} / \mathrm{s}$. Water discharged from the production well was pumped about $60 \mathrm{~m}$ from the pumped well through a 10-cm-diameter hose to prevent recharge to the surficial aquifer near the wells during the test. Water levels were measured in the pumped well every 0.25 seconds using a pressure transducer connected to a datalogger. Water levels in the five observation wells were measured by steel tape to the nearest $0.03 \mathrm{~cm}$.

Drawdown was corrected for the decrease in saturated thickness (dewatering) of the unconfined surficial aquifer using a method presented by Jacob (1963). Dewatering effects in the surficial aquifer during the test were minimal because the maximum drawdown of $7.5 \mathrm{~cm}$ was relatively small compared to the aquifer thickness of 6.1 
m. Because measured drawdowns were much less than 0.2 times aquifer saturated thickness, the effects of partial penetration on drawdown also were minimal. Therefore, it was valid to assume that the measured drawdowns were representative of fully penetrating wells (Weeks, 1969).

The aquifer-test site consisted of a verticallyanisotropic, unconfined aquifer with partiallypenetrating observation wells and a partially-penetrating pumped well. Unfortunately, type curves have not been published for this conceptual model. The water-level responses to pumping, however, closely resemble the type curves for fully-penetrating wells in an isotropic, unconfined aquifer with delayed yield from storage (Boulton, 1963). The Boulton conceptual model for an isotropic aquifer was valid for this test because the pumped well and all observation wells were screened at approximately the same depth within the aquifer and the pumping rate was only $1.6 \mathrm{~L} / \mathrm{s}$; therefore, ground-water flow was essentially horizontal between the wells during the test. Evidence of horizontal ground-water flow was reflected in the fact that the maximum drawdown measured in the observation wells represented less than 2 percent of the saturated thickness.

A logarithmic plot of drawdown versus time divided by radius squared $\left(t / r^{2}\right)$ was prepared for each observation well. A composite plot for all wells was superimposed on the dimensionless Boulton (1963) type curves of $4 \pi \mathrm{Ts} / \mathrm{Q}$ versus $4 \mathrm{Tt} / \mathrm{r}^{2} \mathrm{~S}_{1}$ where,

$\mathrm{T}=$ the transmissivity of the aquifer $\left[\mathrm{L}^{2} / \mathrm{t}\right]\left(\mathrm{m}^{2} / \mathrm{d}\right)$,

$s$ =the drawdown in the observation well $[\mathrm{L}](\mathrm{m})$,

$Q=$ the discharge of the pumped well $\left[\mathrm{L}^{3} / \mathrm{t}\right]\left(\mathrm{m}^{3} / \mathrm{d}\right)$,

$\mathrm{t}=$ time $[\mathrm{t}](\mathrm{d})$,

$r=$ the distance of the observation well from the pumped well $[\mathrm{L}](\mathrm{m})$, and

$S_{1}=$ the storage coefficient of the aquifer for later values of $t$ [dimensionless].

A match point was obtained for values of $\mathrm{s}$ and $\mathrm{t} / \mathrm{r}^{2}$ where both dimensionless Boulton type-curve parameters $4 \pi \mathrm{Ts} / \mathrm{Q}$ and $4 \mathrm{Tt} / \mathrm{r}^{2} \mathrm{~S}_{1}$ were set equal to 1.0 . The transmissivity and storage coefficient of the aquifer were then calculated using the following equation described by Boulton:

$$
T=\frac{(1.0) Q}{4 \pi s}
$$

and,

$$
S_{1}=\frac{4 T t}{r^{2}(1.0)}
$$

where all variables are as described above. The hydraulic conductivity of the aquifer was then calculated using the following relationship:

$$
K=\frac{T}{b}
$$

where,

$$
\begin{aligned}
& \mathrm{K}=\text { the hydraulic conductivity }[\mathrm{L} / \mathrm{t}](\mathrm{cm} / \mathrm{s}) \text {, and } \\
& \mathrm{b}=\text { the saturated thickness of the aquifer }[\mathrm{L}](\mathrm{cm}) \text {. }
\end{aligned}
$$

\section{Ground-Water Recharge}

Recharge to the surficial aquifer was estimated using a method of hydrograph analysis described by Rasmussen and Andreason (1959). The method assumes that waterlevel rises in wells result from areal recharge and that the rate of recharge per year nearly equals the sum of individual water-level rises within the year multiplied by the specific yield of the aquifer. The water-level rise thus calculated, however, falls short of the true water-level rise by the amount of water-level decline that would have occurred if recharge had not taken place. To account for this part of recharge, the hydrograph, prior to the rise, is extrapolated to the date on which the water-level peak occurred (fig. 8). The corrected recharge rate, therefore, equals the difference between the peak stage and the projected water-level decline, on the day of the waterlevel rise, multiplied by the specific yield of the aquifer.

\section{Water Sampling Protocols and Procedures}

Baseline water quality of the surficial aquifer in the research area was determined by collecting ground-water samples from 29 observation wells screened at the water table. The samples were collected during April 1991, before application of agricultural chemicals on the MSEA cropped areas. The wells were placed in one of four groups based on land use and geographic setting as follows: (1) seven wells in the research area affected by previous land use (field wells), (2) six wells immediately upgradient (west) of the research area (upgradient wells), (3) three wells near the wetland adjacent to Battle Brook, along the north edge of the research area (wetland wells), and (4) 13 wells within the study area outside the research 


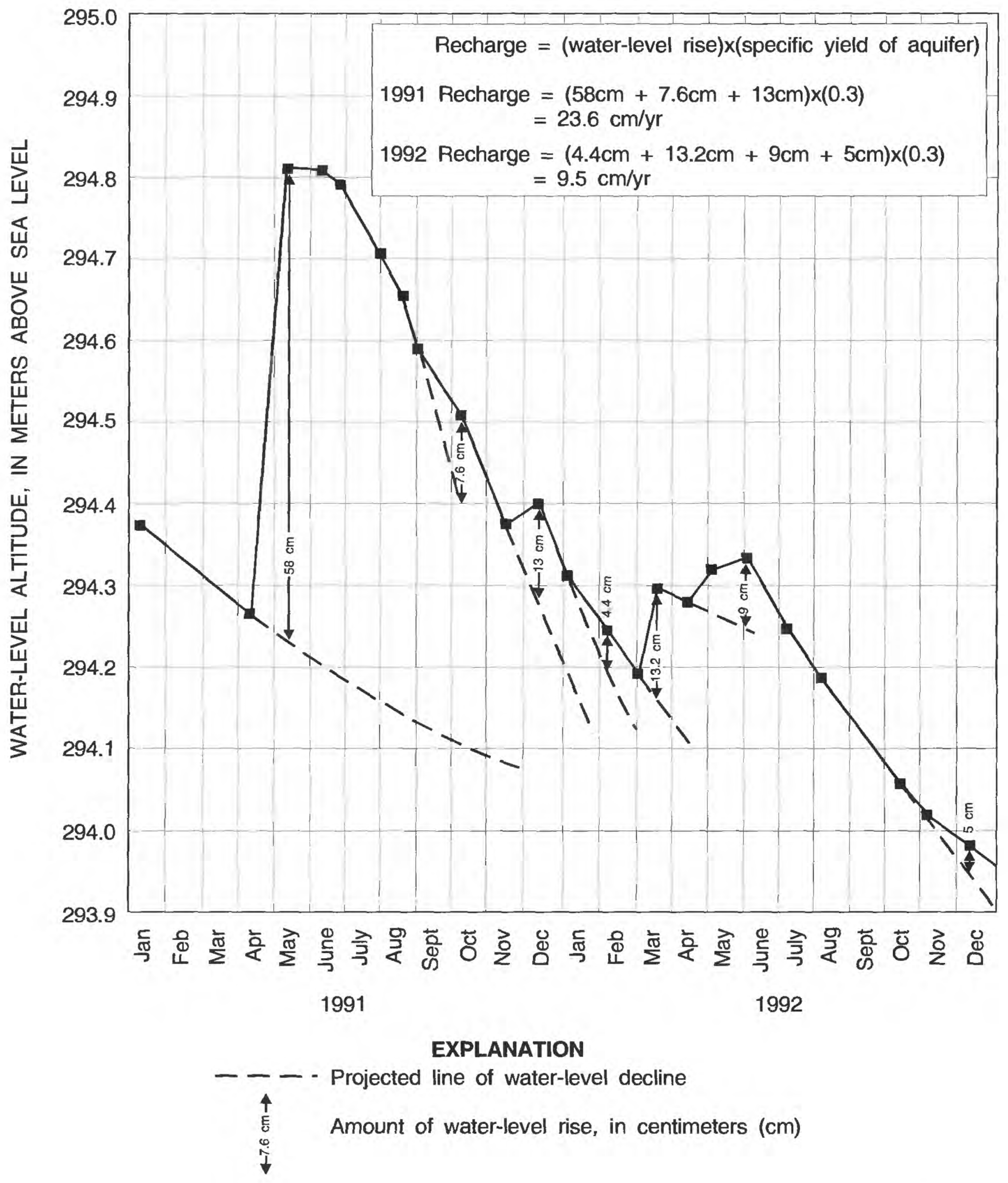

Figure 8.-Water-level hydrograph and recharge calculations for observation well MC28 at the Princeton, Minnesota, Management Systems Evaluation Area, 1991-92. 
area (off-site wells). Water samples were also collected from Battle Brook, at the northeast corner of the research area, and from two domestic wells located northeast of the research area. One domestic well was completed in the confined-drift aquifer and the other in the Mount SimonHinckley aquifer.

The following section of the report describes the procedures used in the collection of water samples at the Princeton MSEA. The protocols discussed below were followed for collecting water samples during the entire MSEA study.

\section{Collection of Water Samples}

A water level was measured in each well prior to sample collection. A peristaltic pump was used to collect ground-water samples from the MPORTs and from most observation wells. Teflon tubing was used, except for approximately $10 \mathrm{~cm}$ of silicone tubing in the peristalticpump head and an approximately $4-\mathrm{cm}$-long piece of silicone tubing used to attach the Teflon tubing to the stainless-steel sampling tubes of the MPORTs or other equipment, such as filter units. The pumping rate using the peristaltic pumps was typically 0.5 to 1.0 liter per minute $(\mathrm{L} / \mathrm{min})$. A submersible stainless-steel Keck pump equipped with Teflon tubing was used for collecting samples from the observation wells, where larger volumes of water were purged. The pumping rate using the Keck pump was typically about $4 \mathrm{~L} / \mathrm{min}$. Stream samples were collected by attaching a float to a length of Teflon tubing connected to a peristaltic pump. The tubing was placed in the stream so that the inlet was about $15 \mathrm{~cm}$ below the water surface.

The pump and tubing was cleaned before sample collection. The procedure consisted of three steps: (1) methanol was pumped through the hoses to remove any residual organic compounds in the tubing from the last sampling; the methanol from this first rinse was not reused; (2) a larger volume of recycled methanol was pumped through the tubing at least three times to ensure removal of organic chemicals in the tubing by dissolution into the methanol; and (3) organic-free, de-ionized (MilliQue) water was pumped through the tubing to remove any residual methanol. The organic-free water was not reused.

The MPORTs were sampled by attaching a $2 \mathrm{~m}$ length of Teflon tubing to the stainless-steel sampling port. Sampling of water-table observation wells with a peristaltic pump required using a 6 to $8 \mathrm{~m}$ length of Teflon tubing. The Teflon tubing was lowered into the well until the tubing inlet was about 10 to $20 \mathrm{~cm}$ below the water table. If a Keck pump was used to sample an observation well, the submersible pump was lowered down the well casing until it was in the well screen.

A minimum of three well volumes were purged from the observation wells before collection of water samples. Because the MPORTs have a very small volume of water in the sampling tube, purging of three well volumes was completed less than one minute after pumping began. To avoid inducing significant vertical flow of ground water between sampling ports, the total pumping time for each MPORT was kept to the minimum time necessary for the field parameters to stabilize (about 8 minutes) and to fill the necessary sample bottles.

The following field parameters were monitored before sampling: specific conductance, $\mathrm{pH}$, temperature, dissolved oxygen (DO), and oxidation-reduction potential (ORP). Field parameters were considered approximately stable when the following criteria were met for at least 2 minutes: (1) a change in specific conductance of less than 3 microsiemens per centimeter $(\mu \mathrm{S} / \mathrm{cm})$ per minute, (2) a change in $\mathrm{pH}$ of less than 0.02 units per minute, and (3) a change in DO of less than 0.1 milligrams per liter $(\mathrm{mg} / \mathrm{L})$ per minute. Field parameters were measured using a multiparameter water-quality monitoring system equipped with a flow-through chamber. The outlet hose from the sampling pump was attached to a flow-through chamber so that the ambient characteristics of the sample water could be monitored without exposure to the atmosphere. The $\mathrm{pH}$ and specific conductance electrodes were calibrated daily to at least two standards before field monitoring began. The DO sensor was calibrated daily to the value of DO in water in equilibrium with the atmosphere. The ORP was measured using an oxidation-reduction platinum electrode. The platinum electrode for measuring ORP was checked against a standard (Zoebel's solution) every day before sample collection to check the accuracy of the measurements and to determine correction factors for measured versus true values.

After the field parameters stabilized, the outlet hose from the peristaltic pump was disconnected from the flow-through chamber and attached to an inorganic filter plate with a 142-millimeter ( $\mathrm{mm}$ )-diameter 0.45 -micron $(\mu \mathrm{m})$ cellulose-nitrate filter. The following inorganic filtered samples were collected: one 500-milliliter (mL) polyethylene bottle for an alkalinity analysis the same day in the field; one 15-mL clear polyethylene bottle for major cation analyses; one 15-mL opaque polyethylene bottle for anion analyses; one 125 - or 250 -mL opaque polyethylene bottle for nutrient analyses. Each sample bottle was rinsed with filtered sample water three times before sample collection. Gas-excluding (polyseal) caps were used for the alkalinity samples to avoid trapping air 
bubbles in the bottle. The cation, anion, and nutrient samples were immediately placed in a cooler with ice. Cation samples were preserved by adding 1 drop of 6 Normal hydrochloric acid and nutrient samples were preserved by adding $0.5 \mathrm{~mL}$ of mercuric chloride solution.

After the alkalinity, cation, anion, and nutrient samples were collected, the Teflon outlet hose from the pump was disconnected from the filter plate and a 1-L-baked-amber glass bottle was filled for herbicides and total organic carbon analyses. The sample was immediately placed in a cooler with ice.

Organic samples collected from April 1991 through December 1991 were filtered through a 47-mm 0.45- $\mu \mathrm{m}$ baked glass-fiber filter in a stainless steel and Teflon filter holder. The filter holder was cleaned between samplings by disassembling the holder, then successively rinsing each part of the filter holder in organic-free water and methanol. The filter holder was reassembled with a new filter after being allowed to dry. Use of the stainless-steel filter holder for collecting organic samples added about 20 minutes to the total time needed to collect each water sample.

Use of the stainless-steel filter holder was discontinued after December 1991 for the following reasons: (1) the excessive length of time required to filter each herbicide sample, (2) very little sediment was present in ground water from most of the wells, and (3) the triazine herbicides evaluated in this study are highly water soluble and are likely to remain in the dissolved phase rather than partition to the sediment. To verify that filtration of the organic samples was unnecessary, both filtered and unfiltered samples were collected from four of the wells. In all cases, the concentrations of herbicides in the unfiltered samples were within the analytical uncertainty of the concentrations in the filtered samples. These results indicated that filtration was not necessary to obtain a representative herbicide concentration. After December 1991, all organic samples were collected unfiltered in a baked 1-L-amber-glass bottle.

\section{Quality Assurance and Quality Control}

Field replicate, equipment blank, split, and spiked samples were collected as part of the quality assurance and quality control (QA/QC) plan at the Princeton MSEA. The field QC samples accounted for 10 to 15 percent of the total number of samples collected. In addition to field $Q C$ samples, each of the analytical laboratories followed a QA/QC plan that included additional analysis of laboratory standards, blanks, replicates, and surrogates.
Field replicates were collected at 3 percent of the sampling sites during each sampling period. Collection of a field replicate sample consisted of filling one container with ground water, three (triplicate) sample bottles were then filled from this container for each of the following analytes: nutrients, cations, anions, and herbicides. The field triplicates primarily were intended to evaluate the reproducibility and precision of the waterquality analytical results. Because two additional analyses were performed for each triplicate set, triplicate samples actually constituted 6 percent of the total samples collected.

Split samples consisted of two samples collected from the same sampling location and submitted to different laboratories. Split samples were collected at the same sampling sites as the replicates ( 3 percent of the sampling locations). One sample was submitted to a referee laboratory for analysis and the other sample was submitted to the regular laboratory. Results of the two analyses were compared to evaluate laboratory bias. Water for the split sample was obtained from the same container in which the replicate samples were collected. The referee laboratory used during 1991 for herbicide analyses was the USGS National Water Quality Laboratory in Arvada, Colorado and during 1992-95 was Twin City Testing in St. Paul, Minnesota. The referee laboratory used for cation, anion, and nutrient analyses during 1991 was the USGS National Water Quality Laboratory in Arvada, Colorado and during 1992-95 was either the Research Analytical Laboratory in the Soil Science Department at the University of Minnesota, St. Paul, Minnesota or the Geochemistry Laboratory in the Department of Geology and Geophysics at the University of Minnesota, Minneapolis, Minnesota, depending on the analyte.

An equipment blank consisted of a sample of organic free, de-ionized water that was pumped through the sampling equipment and collected following the same procedures as with environmental samples previously discussed. Results of the analyses were used to identify contamination from the field sampling equipment. Equipment blanks were collected at 3 percent of the sampling locations.

A spiked sample consisted of a known mass of a herbicide added to a water sample collected from the same sampling locations as the field replicates. Both the spiked and unspiked samples were then analyzed. By comparing the measured concentrations of the target herbicides and metabolites in the spiked sample to calculated concentrations, the amount of recovery of each individual compound could be identified. The calculated concentrations were based on the mass of each compound 
added to the spike and the concentrations of the target herbicides in the unspiked water sample. If the recovery for a given compound was consistently less than 100 percent, either the compound had undergone degradation after the sample was collected (loss) or the entire mass of the target herbicide had not been detected. When multiple spikes at the same concentration were performed on the same sample, the accuracy and precision of the analyses could be evaluated. Spikes of atrazine at concentrations of 0.05 and $0.10 \mu \mathrm{g} / \mathrm{L}$ were collected at selected sampling sites to evaluate the analytical precision and accuracy at these concentration levels. Water for spiked samples was collected from the same large container as the replicates and splits. Spiked samples constituted 3 to 6 percent of the total samples collected.

\section{Laboratory Analyses}

Alkalinity titrations were completed in the field on the same day that the samples were collected. From April 1991 through April 1992, one measurement of alkalinity was completed using the incremental titration method (using a pH meter) and two measurements were completed using a colorimetric method (Hach Company, 1992, method 8203). For all measurements, a Hach digital titrator was used to deliver 0.16 - or 1.6 -Normal sulfuric acid to the sample. If the three measurements agreed within 3 percent, the alkalinity determined from the inflection point in the incremental titration curve was used as the reported value. If the measurements did not agree within 3 percent, additional measurements using both methods were performed until a consistent and reproducible value was obtained. The final reported alkalinity value was always determined from the inflection point in the incremental titration curve. Colorimetric tests were initially completed only as a check on the incremental titration method. After completing several hundred measurements (through April 1992), however, results of the colorimetric and incremental-titration methods were deemed virtually identical, with a 1:1 relationship. Results using the two methods were shown to be identical for a wide range of alkalinities and initial $\mathrm{pH}$ 's. Therefore, the colorimetric method was used for alkalinity measurements after April 1992. Two colorimetric tests were completed for every sample. If results of the two tests did not agree within 3 percent, additional measurements were completed until a consistent and reproducible value for the alkalinity was obtained.

Samples to be analyzed for nutrients, cations, and anions were stored in a refrigerator at the USGS office in Mounds View, Minnesota. Samples were delivered to the respective laboratories within a few days to, at most, one week.

Analyses for cations and anions were completed by the Geochemistry Laboratory in the Department of Geology and Geophysics at the University of Minnesota, Minneapolis, Minnesota. Cations were analyzed using inductively coupled plasma-mass spectroscopy (ICPMS) (Rick Knurr, Department of Geology and Geophysics, University of Minnesota, oral commun., 1994). Cation analytes included calcium, magnesium, sodium, potassium, aluminum, iron, manganese, strontium, barium, and silica. Anions were analyzed using ion chromatography (IC) using USEPA method 300.0 (U.S. Environmental Protection Agency, 1983) (E.C. Alexander, Department of Geology and Geophysics, University of Minnesota, written commun., 1991). Anion analytes included chloride, bromide, nitrite nitrogen, nitrate nitrogen, sulfate, orthophosphate, and fluoride. The geochemistry laboratory followed an internal set of QA/QC protocols using analyses of blanks, standards, and replicates to evaluate QC (E.C. Alexander, Department of Geology and Geophysics, University of Minnesota, written commun., 1991). Each sample was analyzed in replicate five times for ICPMS analyses and two times for IC analyses. Cation-anion charge balances were used as a check on the accuracy of the analyses. The laboratory participated in the USGS reference sample program.

Analyses for nutrients were completed by the Research Analytical Laboratory in the Soil Science Department at the University of Minnesota, St. Paul, Minnesota, using colorimetric methods (R.C. Munter, Department of Soil Science, University of Minnesota, written commun., 1991). Nutrient analytes included nitrate plus nitrite nitrogen, ammonium nitrogen, total kjeldahl nitrogen (ammonium plus organic nitrogen), and total phosphorus. Standard USEPA methods of analysis were used for all analytes (U.S. Environmental Protection Agency, 1983). For example, analyses for nitrite plus nitrate nitrogen were completed using a colorimetric, automated, cadmium reduction process using USEPA method 353.2 (U.S. Environmental Protection Agency, 1983). The laboratory followed an internal set of QA/QC protocols using analyses of blanks, standards, and replicates to evaluate QC. The laboratory participated in the USGS reference sample program.

Samples to be analyzed for herbicides were delivered to a USGS Laboratory at the Gray Freshwater Biological Institute in Navarre, Minnesota either the day of or the day after they were collected. Samples were analyzed for herbicides using gas chromatography and mass spectroscopy (GC/MS) following extraction of the 
herbicides from the water sample using a solid-phase extraction technique (P.D. Capel, U.S. Geological Survey, written commun., 1991). Herbicide analytes included atrazine and atrazine metabolites deethylatrazine and de-isopropylatrazine; alachlor and alachlor metabolites 2,6-diethylanaline and chloroalachlor; metolachlor; and metribuzin. The laboratory followed an internal set of $\mathrm{QA} / \mathrm{QC}$ protocols using analyses of blanks, standards, surrogate compound spikes, laboratory spikes of target analytes, and replicates to evaluate $\mathrm{QC}$. Blind samples from a referee laboratory were analyzed to evaluate laboratory bias. Every sample was spiked with surrogate compounds to evaluate recovery. Subsamples of selected I-L herbicide samples were sent to the USGS National Water Quality Laboratory in Arvada, Colorado to be analyzed for total or dissolved organic carbon.

The herbicide laboratory in Navarre, Minnesota developed compound-specific reporting and detection limits for each of the analytes. The quantitative reporting limit was defined as the concentration at which there was a 99 percent confidence in the reported concentration. The qualitative detection limit was defined as the minimum concentration at which the analyte could be detected by GC/MS. Concentrations greater than or equal to the qualitative detection limit but less than the quantitative reporting limit indicated trace concentrations of the analytes, or concentrations that could not be reliably assigned a quantitative value but indicated that the analytes were present. The qualitative detection limit for atrazine, alachlor, 2,6-diethylanaline, and metolachlor was $0.01 \mu \mathrm{g} / \mathrm{L}$ and the quantitative reporting limit was $0.04 \mu \mathrm{g} / \mathrm{L}$. The qualitative detection limit for deethylatrazine and metribuzin was $0.03 \mu \mathrm{g} / \mathrm{L}$ and the quantitative reporting limit was $0.06 \mu \mathrm{g} / \mathrm{L}$. The qualitative detection limit for de-isopropylatrazine and chloroalachlor was $0.06 \mu \mathrm{g} / \mathrm{L}$ and the quantitative reporting limit was $0.08 \mu \mathrm{g} / \mathrm{L}$.

The immunoassay technique (Thurman and others, 1990) was also used to detect atrazine and alachlor during the April and June 1991 sampling periods, prior to quantitative analysis by GC/MS. Immunoassay is a screening method used to provide a semi-quantitative determination of the presence or absence of the target compounds. The triazine immunoassay method is most sensitive to the presence of atrazine but also has a very low sensitivity to atrazine metabolites de-ethylatrazine and de-isopropylatrazine. All samples collected during April 1991 were analyzed using both immunoassay and GC/MS. Samples collected during the June 1991 sampling period in which either triazine herbicides or alachlor were detected by immunoassay were analyzed by GC/MS, for quantitative confirmation. Selected samples in which triazine herbicides and alachlor were not detected by immunoassay during the June 1991 sampling period were also analyzed by GC/MS for quality control.

\section{Statistical Analyses}

The relations between selected chemical constituents were evaluated using both parametric (Pearson) and nonparametric (Kendall) correlations. Correlation coefficients provide a measure of the strength of association between two variables. However, a high correlation coefficient between two variables does not necessarily indicate a direct causal relation between the two variables (Helsel and Hirsch, 1992). The Pearson correlation measures the linear association between two variables. Because the Pearson correlation is not resistant to outliers and assumes the data follow a normal distribution, all significant Pearson correlations were plotted graphically to verify that the data approximately met the requirements of the test.

Kendall correlations were calculated as a comparison to the Pearson correlations. Results of the two correlation methods were similar. Correlation coefficients referred to in this report are Pearson coefficients. The attained significance level ( $p$-value) was calculated and compared to a predetermined significance level $(\alpha=0.05)$ to determine when a correlation was statistically significant. The $\mathrm{p}$-value is the probability of obtaining the computed test statistic when the null hypothesis (no correlation between variables) is true. The smaller the $p$-value, the less likely is the observed test statistic when the null hypothesis is true (Helsel and Hirsch, 1992). If the pvalue was less than $\alpha$ the null hypothesis was rejected and the correlation was considered significant. All statistics were determined using SAS statistical software (SAS Institute Inc., 1989).

\section{HYDROGEOLOGY}

\section{A thorough description of the hydrogeologic}

framework is necessary to assess the movement and fate of agricultural chemicals at the Princeton MSEA. The following sections of the report describe the geologic and hydraulic information used to characterize the hydrogeology in the research area.

Glacial deposits in the research area were subdivided into seven general hydrogeologic units (figs. 9, 10, and 11) as follows, in order of increasing depth below land surface: (1) topsoil, (2) fine to medium sand, (3) medium sand, (4) coarse to very coarse sand and gravel, (5) interbedded sand and till, (6) clayey till, and (7) coarse to very coarse sand. The Mount Simon-Hinckley bedrock aquifer underlies the glacial deposits (fig. 9). 


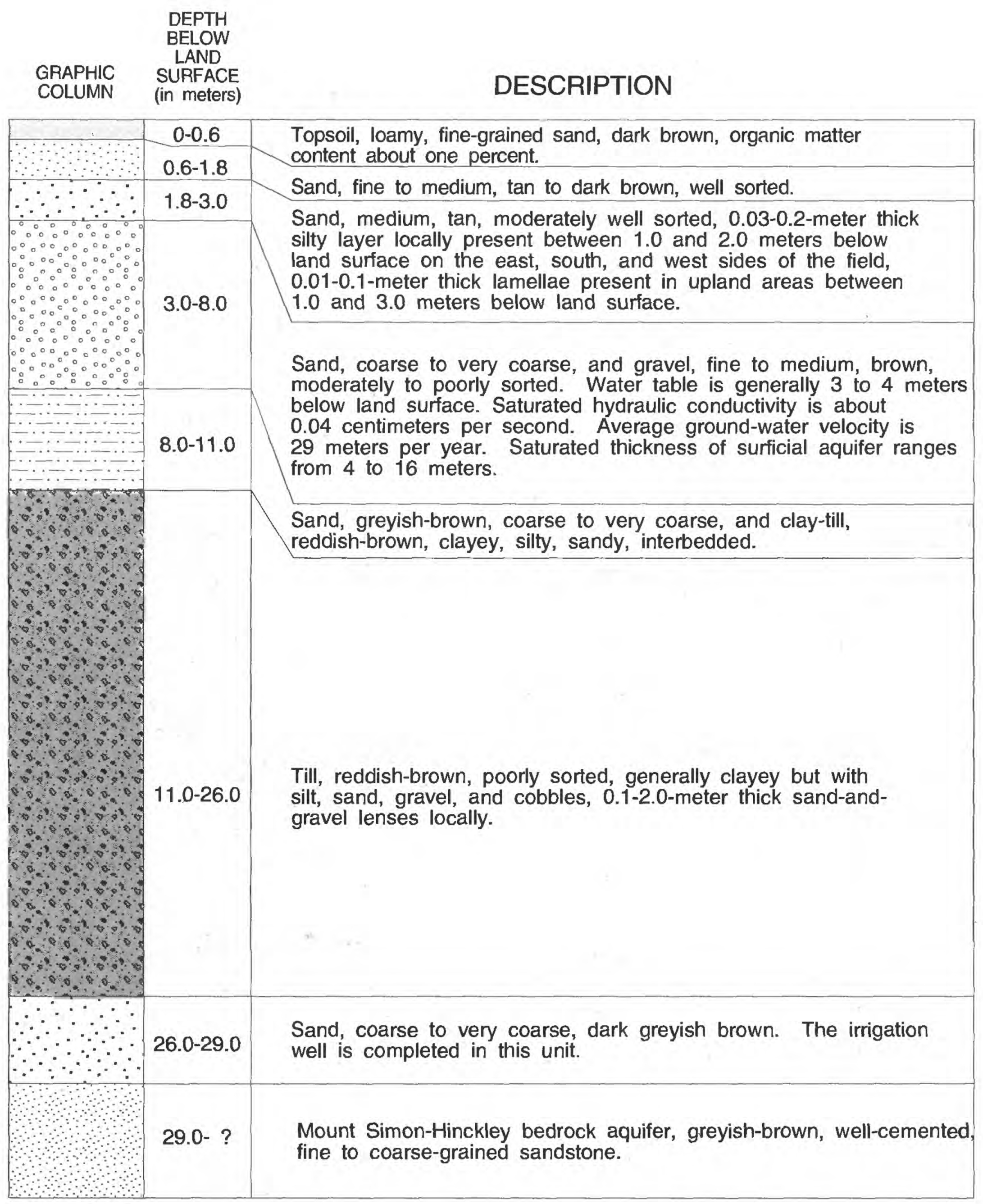

Figure 9.--Diagram showing generalized stratigraphic section and hydrogeologic properties at the Princeton, Minnesota Management Systems Evaluation Area. 

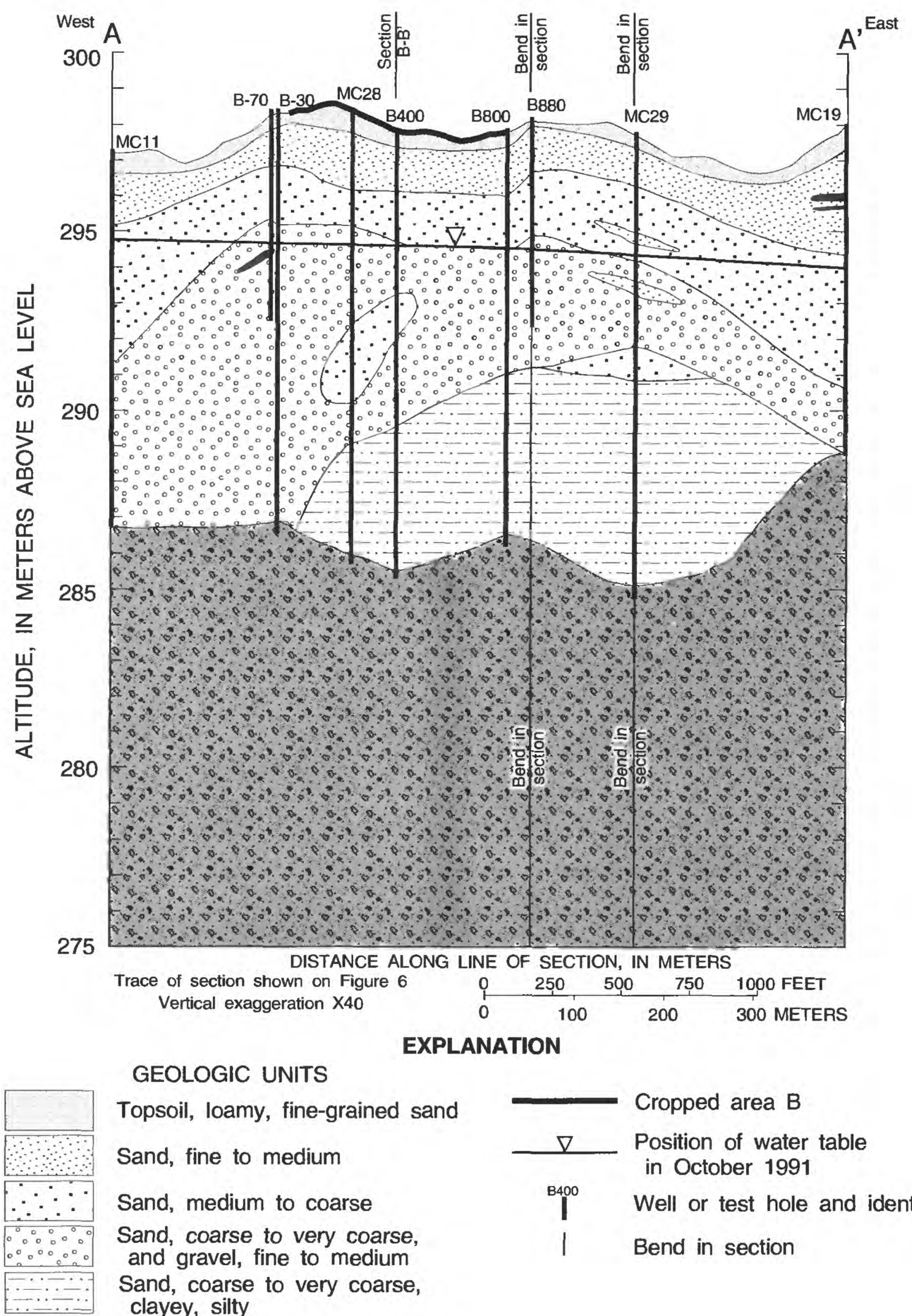

GEOLOGIC UNITS

Topsoil, loamy, fine-grained sand

Sand, fine to medium

Sand, medium to coarse

Sand, coarse to very coarse, and gravel, fine to medium

Cropped area B

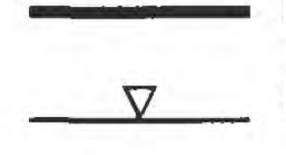

Position of water table in October 1991

B400 Well or test hole and identifier

Bend in section

Sand, coarse to very coarse, clayey, silty

Silt and very fine sand

$\rightarrow+0$ Till, clayey

Figure 10.-Hydrogeologic section A-A' through the Princeton, Minnesota Management Systems Evaluation Area. 

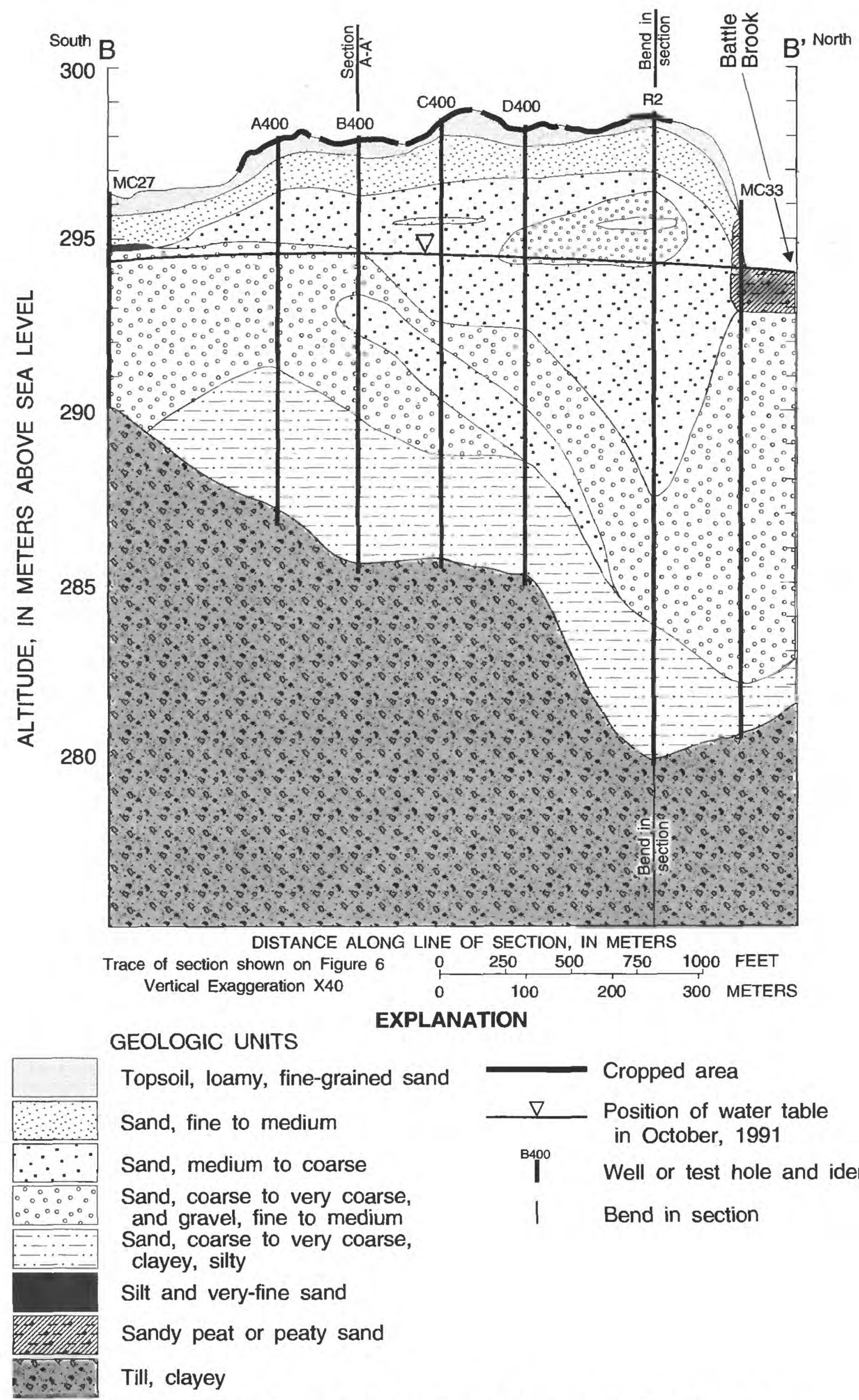

Topsoil, loamy, fine-grained sand

Cropped area

Sand, fine to medium

Sand, medium to coarse

Sand, coarse to very coarse, and gravel, fine to medium

Sand, coarse to very coarse, clayey, silty

Silt and very-fine sand

Sandy peat or peaty sand

Till, clayey

Figure 11.--Hydrogeologic section B-B' through the Princeton, Minnesota Management Systems Evaluation Area. 
The research area is underlain by glacial deposits that resulted from several glacial advances and retreats during the Pleistocene glaciation (Wright, 1972a, Wright, 1972b, and Wright and Ruhe, 1965). The upper 4 to $15 \mathrm{~m}$ of glacial deposits (figs. 9, 10, and 11) are part of the Anoka Sand Plain (surficial) aquifer (fig. 2). The sand plain was formed during the eastward diversion of the glacial Mississippi River around the Grantsburg sublobe of the Wisconsin glaciation (Cooper, 1935, and Farnham, 1956). The sand plain formed primarily due to glaciofluvial processes as the glacial ice melted. It is likely that limited eolian activity occurred in the research area, although this was not a major process affecting the physiography at the research area. About 6 percent of the Anoka Sand Plain, including an area immediately south of the Sherburne National Wildlife Refuge (fig. 3), was re-worked by eolian processes (Cooper, 1935).

Underlying the surficial aquifer is red till deposited by the Superior lobe of the Wisconsin glaciation (Cooper, 1935, and Farnham, 1956). This glacial lobe expanded out of the Lake Superior Basin into the area. Gray till deposited by the Grantsburg sublobe is also present locally within the surficial aquifer in the research area.

\section{Soils}

The principal soil type in the research area is the Zimmerman fine sand series (Grimes, 1968). These 0.4 to $1.0 \mathrm{~m}$ thick, dark-brown soils developed in loose, finegrained, glacial outwash sands sorted by water and wind. Seven distinct soil types were identified and delineated at a scale of 1:12,000 (Tom Jackson, USDA-Soil Conservation Service, written commun., 1991) (table 1) (fig. 12). The soil types were delineated based on differences in: (1) texture; (2) color; (3) thickness of the surface soil, subsoil, and underlying materials; (4) internal drainage characteristics; (5) landscape position; and (6) landslope. An eighth type of organic soils was also identified near Battle Brook. This soil type is not extensive enough to map at a scale of $1: 12,000$, however, and is not included on figure 12 .

Mean values for soil texture, organic-carbon content, bulk density, and saturated hydraulic conductivity (table 2) were based primarily on analyses of 50 samples collected from cropped areas B and D (fig. 12, sites W1 and W2). These data were supplemented with limited data collected elsewhere in the research area. The upper $1.5 \mathrm{~m}$ in cropped areas B and D consists primarily of fine sand. Greater than 92 percent (by weight) of the soil is composed of sand-sized particles atall depths in the upper $1.5 \mathrm{~m}$ (table 2). Silt- and clay-sized particles account for 8 percent or less of the soil. The particle-size distribution is similar in the upper $1.5 \mathrm{~m}$ throughout the research area. Organic-carbon content was greatest in the upper $35 \mathrm{~cm}$
( 0.5 percent) and decreased to 0.1 percent at the 120 to $150 \mathrm{~cm}$ depths (table 2). Bulk densities ranged from 1.41 to $1.48 \mathrm{~g} / \mathrm{cm}^{3}$, based on 50 analyses. The hydraulic conductivity increases with depth from $0.0035 \mathrm{~cm} / \mathrm{s}$, at the 0 to $20 \mathrm{~cm}$ depths, to $0.0077 \mathrm{~cm} / \mathrm{s}$ at the 120 to $150 \mathrm{~cm}$ depths.

The Zimmerman soils are highly permeable with an infiltration rate of 2 to $5 \mathrm{~cm}$ per hour (Grimes, 1968). Moisture-retention characteristics (table 3 ) were measured to a depth of $150 \mathrm{~cm}$ in cropped areas B and D sites W1 and W2 (fig. 12). Soil-water contents varied with depth at each of the sites. The difference in water content between 0.1 bar and 15 bar (table 3) represents water that is available for plant growth and is important for irrigation management (Wright and Bergsrud, 1991). If the soil was dried to 15 bar by plant removal of water, 6.9 and $11.1 \mathrm{~cm}$ of rainfall would be required to fill the soil to field capacity in cropped areas B and D, respectively (table 3). The Zimmerman soil has a low water-holding capacity, compared to other soils in Minnesota, that predisposes plants without irrigation to drought stress (U.S. Department of Agriculture, 1992, p. 104-125). In addition, the surficial aquifer is more susceptible to contamination from chemicals that leach through these soils with lower water-holding capacity.

\section{Surficial Aquifer}

A layer of sand that is fine to medium grained and well sorted underlies the topsoil in most parts of the research area (figs. 9,10, and 11). This unit generally is 1 to $2 \mathrm{~m}$ thick but is greater than $3 \mathrm{~m}$ thick on the eastern side of the research area (fig. 10). In the topographically higher (upland) parts of the research area (fig. 5) the unit is slightly finer, better sorted, and has a smaller percentage of silt- and clay-sized particles than in topographically lower (lowland) parts of the area (Delin and others, 1994). Discontinuous iron-rich layers, or lamellae, are present in the unsaturated zone in upland areas between the 1 and 2 $m$ depths (Delin and Landon, in press; and Tomer, 1994). The lamellae are 2 to $20 \mathrm{~cm}$ thick, are cemented with iron oxides, and contain an average of 5-10 percent silt and clay compared to less than about 5 percent in adjacent horizons. Similar iron-rich lamellae have been identified throughout the Anoka Sand Plain (Farnham, 1956; Bouabid, 1992). In addition to the lamellae, 3 to $20 \mathrm{~cm}$ thick layers of silty sand are present throughout the glacial deposits but primarily are present between the 1 and $2 \mathrm{~m}$ depths (figs. 9, 10, and 11). These silty sand layers are generally present on the east, south, and west sides of the research area.

A second sand unit of variable thickness is present between about 2 and $10 \mathrm{~m}$ below land surface in the 
Table 1.--Description of soil map units at the Princeton, Minnesota Management Systems Evaluation Area

[cm, centimeters; <, less than; >, greater than;--, unnamed soil; (modified from

Tom Jackson, U.S. Department of Agriculture, Soil Conservation Service, written commun., 1991)]

\begin{tabular}{|c|c|c|c|c|c|}
\hline $\begin{array}{l}\text { Soil } \\
\text { type }\end{array}$ & $\begin{array}{c}\text { Soil } \\
\text { name }\end{array}$ & $\begin{array}{c}\text { Slope } \\
\text { (percent) }\end{array}$ & $\begin{array}{l}\text { Taxonomic } \\
\text { classification }\end{array}$ & $\begin{array}{l}\text { Organic-matter } \\
\text { content in upper } 20 \text {. } \\
60 \mathrm{~cm} \text { (percent) }\end{array}$ & Other characteristics \\
\hline $158 \mathrm{~A}$ & $\begin{array}{l}\text { Zimmerman } \\
\text { fine sand }\end{array}$ & $0-2$ & $\begin{array}{l}\text { Mixed, frigid } \\
\text { Argic } \\
\text { Udipsamments }\end{array}$ & $<1$ & $\begin{array}{l}\text { The organic-matter content of this well- } \\
\text { drained soil decreases consistently with } \\
\text { depth. }\end{array}$ \\
\hline 158AM & $\begin{array}{l}\text { Zimmerman } \\
\text { fine sand }\end{array}$ & $0-2$ & $\begin{array}{l}\text { Mixed, frigid } \\
\quad \text { Argic } \\
\text { Udipsamments }\end{array}$ & $>1$ & $\begin{array}{l}\text { There is an irregular decrease in the organic- } \\
\text { matter content within the upper } 50 \mathrm{~cm} \text { of this } \\
\text { well-drained soil. The predominant surface } \\
\text { texture within this map unit is fine sand. } \\
\text { However, limited areas with loamy fine-sand } \\
\text { texture are also present. Wind erosion depos- } \\
\text { ited } 12 \text { to } 25 \mathrm{~cm} \text { of topsoil over the original } \\
\text { surface. }\end{array}$ \\
\hline $158 \mathrm{~B}$ & $\begin{array}{l}\text { Zimmerman } \\
\text { fine sand }\end{array}$ & $2-6$ & $\begin{array}{l}\text { Mixed frigid Argic } \\
\text { Udipsamments }\end{array}$ & $<1$ & $\begin{array}{l}\text { The organic-matter content of this well- } \\
\text { drained soil decreases consistently with } \\
\text { depth. }\end{array}$ \\
\hline 161 & $\begin{array}{l}\text { Isanti fine } \\
\text { sandy loam }\end{array}$ & $0-1$ & $\begin{array}{l}\text { Sandy, mixed, } \\
\text { frigid Typic } \\
\text { Endoaquolls }\end{array}$ & $>4$ & $\begin{array}{l}\text { This very poorly drained soil is present in } \\
\text { small depressional areas of } 0.4 \text { to } 0.8 \text { hectares } \\
\text { in size. Small transitional areas around this } \\
\text { map unit may exist within the research area } \\
\text { but their extent was insufficient to map at a } \\
\text { scale of } 1: 12,000 \text {. }\end{array}$ \\
\hline 260 & $\begin{array}{l}\text { Duelm loamy } \\
\text { sand }\end{array}$ & $0-1$ & $\begin{array}{l}\text { Sandy, mixed, } \\
\text { frigid Aquic } \\
\text { Haploborolls }\end{array}$ & $>2$ & $\begin{array}{l}\text { This moderately well drained soil is present } \\
\text { near the wetland adjacent to Battle Brook. } \\
\text { Organic-matter content in the upper } 30 \mathrm{~cm} \\
\text { decreases gradually with depth. }\end{array}$ \\
\hline 2409 & $\begin{array}{l}\text { Cantlin loamy } \\
\text { fine sand }\end{array}$ & $0-2$ & $\begin{array}{l}\text { Sandy, mixed, } \\
\text { frigid Typic } \\
\text { Udipsamments }\end{array}$ & $0.5-2$ & $\begin{array}{l}\text { This moderately well drained soil is present } \\
\text { immediately northeast of cropped area } \mathrm{E} \text {, } \\
\text { near the wetland. Organic matter exceeds } 2 \\
\text { percent locally. }\end{array}$ \\
\hline $\mathrm{H}$ & -. & $0-2$ & $\begin{array}{c}\text { Sandy, mixed } \\
\text { Entic Haploborolls }\end{array}$ & $>2$ & $\begin{array}{l}\text { This map unit is present within a } 0.4-\text { to } 0.8 \text { - } \\
\text { hectare area in the northeastem part of the } \\
\text { research area and does not meet established } \\
\text { series criteria. It is an area where wind ero- } \\
\text { sion has, in part, deposited } 10 \text { to } 25 \mathrm{~cm} \text { of soil } \\
\text { material over the original soil surface. } \\
\text { Smaller areas exhibiting similar characteris- } \\
\text { tics are present within map units } 158 \mathrm{~A}, 158 \mathrm{~B} \text {, } \\
\text { and } 158 \mathrm{AM} \text { but were not extensive enough to } \\
\text { map. }\end{array}$ \\
\hline
\end{tabular}

research area (figs. 9, 10, and 11). This sand unit is medium grained and moderately well sorted. The thickness of this unit is greatest beneath cropped area $\mathrm{E}$ and thins to the south and is missing near well MC27 (fig. 11). In most locations, the water table is within or near the bottom of this unit. The unit contains layers $(5$ to $20 \mathrm{~cm}$ thick) of silty sand and layers of coarse sand to fine gravel (figs, 10and 11). These coarser layers are most prominent in the northern part of the research area (fig. 11).

A gravel and sand unit underlies the medium-grained sand throughout the research area (figs. 9, 10, and 11). 


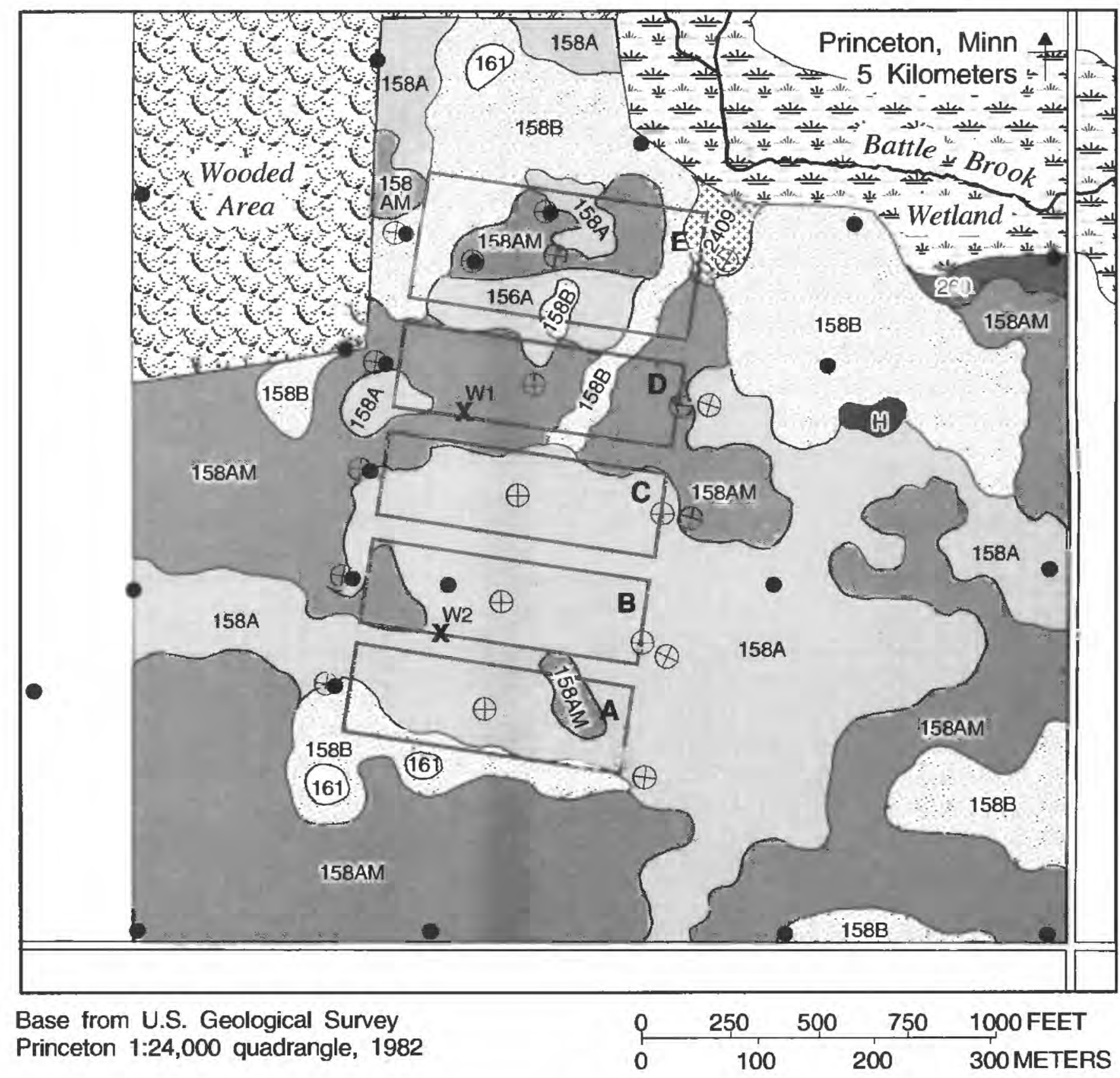

EXPLANATION

SOIL TYPES (Detailed description in Table 1)

158A

Fine sand, 0 to 2 percent slopes, 0 to 1 percent organic matter

158AM Fine sand or loamy fine sand, 0 to 2 percent slopes greater than 1 percent organic matter

158B Fine sand, 2 to 6 percent slopes, 0 to 1 percent organic matter

161 Fine sandy loam, greater than 4 percent organic matter

260 Loamy sand, greater than 2 percent organic matter

240amy fine sand, typically 0.5 to 2 percent organic matter but in places it can be greater than 2 percent

보 Loamy fine sand A Boundary of cropped
area and identifier

- Observation well

$\mathrm{X}^{\text {W1 }}$ Sample collection location for soil analyses and identifier

$\oplus \quad$ Multiport well

The research area is located in the northeast quarter of section 18, township T35N, range $R 26 W$

(Tom Jackson, U.S. Department of Agriculture - Soil

Conservation Service, written communication, 1991)

Figure 12.-Soils at the Princeton, Minnesota Management Systems Evaluation Area. 
Table 2.--Median values of soil texture, organic-carbon content, bulk density, and saturated hydraulic conductivity for the upper 1.5 meters of the unsaturated zone in cropped areas $B$ and D at the Princeton, Minnesota Management Systems Evaluation Area

[\% by wt, percent by weight; $\mathrm{g} / \mathrm{cm}^{3}$, grams per cubic centimeter; $\mathrm{cm} / \mathrm{s}$, centimeters per second]

\begin{tabular}{ccccccc}
\hline $\begin{array}{c}\text { Range in } \\
\text { depth below } \\
\text { land surface } \\
\text { (centimeters) }\end{array}$ & $\begin{array}{c}\text { Sand } \\
(\% \text { by wt) }\end{array}$ & $\begin{array}{c}\text { Silt } \\
(\% \text { by wt) }\end{array}$ & $\begin{array}{c}\text { Clay } \\
(\% \text { by wt) }\end{array}$ & $\begin{array}{c}\text { Organic- } \\
\text { carbon } \\
\text { content } \\
(\% \text { by wt })\end{array}$ & $\begin{array}{c}\text { Bulk } \\
\text { density } \\
\left(\mathrm{g} / \mathrm{cm}^{3}\right)\end{array}$ & $\begin{array}{c}\text { Saturated } \\
\text { hydraulic } \\
\text { conductivity } \\
(\mathrm{cm} / \mathrm{s})\end{array}$ \\
\hline $0-20$ & 95 & 2 & 3 & 0.5 & 1.43 & 0.0035 \\
$20-35$ & 93 & 3 & 4 & .5 & 1.48 & .0031 \\
$35-60$ & 93 & 4 & 3 & .4 & 1.43 & .0072 \\
$60-90$ & 92 & 5 & 3 & .3 & 1.41 & .0074 \\
$90-120$ & 97 & 1 & 2 & .2 & 1.42 & .0082 \\
$120-150$ & 98 & 1 & 1 & .1 & 1.43 & .0077 \\
\hline
\end{tabular}

Table 3.--Moisture-retention characteristics for the upper 1.5 meters of the unsaturated zone for cropped areas B and D at the Princeton, Minnesota Management Systems Evaluation Area [cm, centimeters]

\begin{tabular}{ccccc}
\hline $\begin{array}{c}\text { Cropped } \\
\text { Area } \\
\text { (figure 6) }\end{array}$ & $\begin{array}{c}\text { Depth below } \\
\text { land surface } \\
\text { (cm) }\end{array}$ & $\begin{array}{c}0.1 \text {-bar } \\
\text { soil-water } \\
\text { content (cm) }\end{array}$ & $\begin{array}{c}15 \text {-bar } \\
\text { soil-water } \\
\text { content (cm) }\end{array}$ & $\begin{array}{c}0.1 \text { to15 bar } \\
\text { plant } \\
\text { available } \\
\text { soil water (cm) }\end{array}$ \\
\hline B & $0-30$ & 3.6 & 1.8 & 1.8 \\
B & $30-60$ & 4.0 & 1.9 & 2.1 \\
B & $60-90$ & 2.6 & 1.4 & 1.1 \\
B & $90-120$ & 1.7 & 1.1 & .6 \\
B & $120-150$ & 2.4 & 1.1 & 1.3 \\
\hline \hline D & $0-30$ & 3.2 & 1.3 & 1.9 \\
D & $30-60$ & 4.5 & 1.5 & 2.9 \\
D & $60-90$ & 3.1 & 1.1 & 2.0 \\
D & $90-120$ & 2.6 & .9 & 1.7 \\
D & $120-150$ & 3.4 & .8 & 2.6 \\
\hline
\end{tabular}


This unit is moderately to poorly sorted, coarse to very coarse sand and fine to medium gravel. This unit is generally about $3 \mathrm{~m}$ thick beneath the cropped areas and is greater than $7 \mathrm{~m}$ thick beneath cropped area A (fig. 11). This unit immediately underlies the Battle Brook peat sediments and reaches its greatest thickness of about $9 \mathrm{~m}$ beneath the northern edge of the research area. A northsouth trending layer of medium- to coarse-grained sand is embedded within this unit beneath cropped areas B, C, D, and $E$ (figs. 10 and 11). In most locations, the water table is above or near the top of this unit.

At the base of the surficial aquifer, underlying most of the research area, is a transition zone between the overlying sand and the underlying red till (figs. 9, 10, and 11). This transition zone is grayish-brown, coarse to very coarse sand, interbedded with gray to reddish-brown, clayey, sandy till. The transition zone varies from being absent on the southern and western sides of the research area to a maximum thickness of about $5 \mathrm{~m}$ near well MC29 (figs. 10 and 11). The sand and gray till within the transition zone were deposited from the Grantsburg sublobe and the reddish-brown till was deposited from the Superior lobe.

Depth to the base of the surficial aquifer is greatest beneath the northernmost cropped area $(19 \mathrm{~m})$ (fig. 11), and least on the southern edge and in the southeastern corner of the research area $(7.5 \mathrm{~m})$ (figs. 11 and 13). The average depth to the water table is about $3.6 \mathrm{~m}$ below land surface and the saturated thickness of the aquifer ranges from about $4 \mathrm{~m}$ to greater than $15 \mathrm{~m}$ (fig. 13).

\section{Hydraulic Properties of the Surficial Aquifer}

Based on results of laboratory analyses (H. W. Olsen, U.S. Geological Survey, written commun., 1993), the median horizontal saturated hydraulic conductivity of the upper meter of the unsaturated zone beneath upland areas $\left(4.2 \times 10^{-3} \mathrm{~cm} / \mathrm{s}\right)$ is slightly greater than beneath lowland areas $\left(3.2 \times 10^{-3} \mathrm{~cm} / \mathrm{s}\right)$ (table 4$)$. The lower hydraulic conductivity in lowland areas results primarily from the smaller particle size when compared to upland areas (Delin and others, in press). Between the 1 and $2 \mathrm{~m}$ depths in the unsaturated zone, the median hydraulic

conductivity beneath lowland areas of $1.29 \times 10^{-2} \mathrm{~cm} / \mathrm{s}$ is about three times larger than the median hydraulic conductivity beneath upland areas of $4.2 \times 10^{-3} \mathrm{~cm} / \mathrm{s}$. The greater hydraulic conductivities between the 1 and $2 \mathrm{~m}$ depths beneath lowland areas results from the coarser particle-size distribution (Delin and others, in press). Between the 2 and $4 \mathrm{~m}$ depths in the unsaturated zone beneath upland areas, the median hydraulic conductivity of $3.2 \times 10^{-3} \mathrm{~cm} / \mathrm{s}$ is similar to the median hydraulic conductivity at shallower depths beneath upland areas (table 4). The median vertical hydraulic conductivity of $6.0 \times 10^{-3} \mathrm{~cm} / \mathrm{s}$, based on four samples collected vertically, is similar to the horizontal hydraulic conductivity (Delin and others, in press).

Hydraulic conductivity values for the unsaturated zone calculated using the Hazen formula (equation 3, p. 14) are about two times greater than results based on laboratory analyses using the triaxial system. Similar to results based on laboratory analyses, hydraulic conductivity values were greatest between the 1 and $2 \mathrm{~m}$ depths. The median hydraulic conductivity between the 1 and $2 \mathrm{~m}$ depths beneath lowland areas $\left(1.7 \times 10^{-2} \mathrm{~cm} / \mathrm{s}\right)$ is about two times greater than the median hydraulic conductivity beneath upland areas $\left(9.0 \times 10^{-3} \mathrm{~cm} / \mathrm{s}\right)$.

The estimate of hydraulic conductivity using the conservative transport of chloride was based on estimates of the time that chloride applied to cropped area A first reached the water table at MPORT A800 and at MPORT A880. Chloride moved along a ground-water-flow path similar to the path shown in figure 7a. Based on analyses of water samples collected from MPORT A800, chloride applied to cropped area $A$ reached this location between August 1 and December 10, 1991. Based on analysis of the first water sample collected from MPORT A880, chloride applied to cropped area $A$ reached this location prior to April 9, 1992. Therefore, the maximum chloride time of travel from MPORT A800 to MPORT A880 was 253 days (August 1, 1991 to April 9, 1992). Using this time in equation 4 yields a minimum hydraulic conductivity of $0.042 \mathrm{~cm} / \mathrm{s}$. The estimated minimum chloride time of travel from MPORT A800 to MPORT A880 was 121 days (December 10, 1991 to April 9, 1992). Inserting this time in equation 4 yields a maximum hydraulic conductivity of $0.089 \mathrm{~cm} / \mathrm{s}$. The mean of these two hydraulic conductivities $(0.0655 \mathrm{~cm} / \mathrm{s})$ agrees favorably with estimates based on slug-test analyses and is within the same order of magnitude as the hydraulic conductivities calculated using the Hazen formula (table 4).

The median hydraulic conductivity of the surficial aquifer based on 47 slug-test analyses was $5.2 \times 10^{-2} \mathrm{~cm} / \mathrm{s}$ (table 4). The median hydraulic conductivity for wells with $15-\mathrm{cm}$ long screens $\left(7.6 \times 10^{-2} \mathrm{~cm} / \mathrm{s}\right)$ was about two times greater than for wells with $60-\mathrm{cm}$ long screens $\left(3.9 \times 10^{-2} \mathrm{~cm} / \mathrm{s}\right)$. This difference likely results from heterogeneities of the aquifer. Because the $60-\mathrm{cm}$ long screens penetrate a greater thickness of aquifer compared to the $15-\mathrm{cm}$ long screens, the longer screens are more likely to penetrate heterogeneities in the aquifer that reduce the hydraulic conductivity locally. Another possible explanation for these differences is that the 


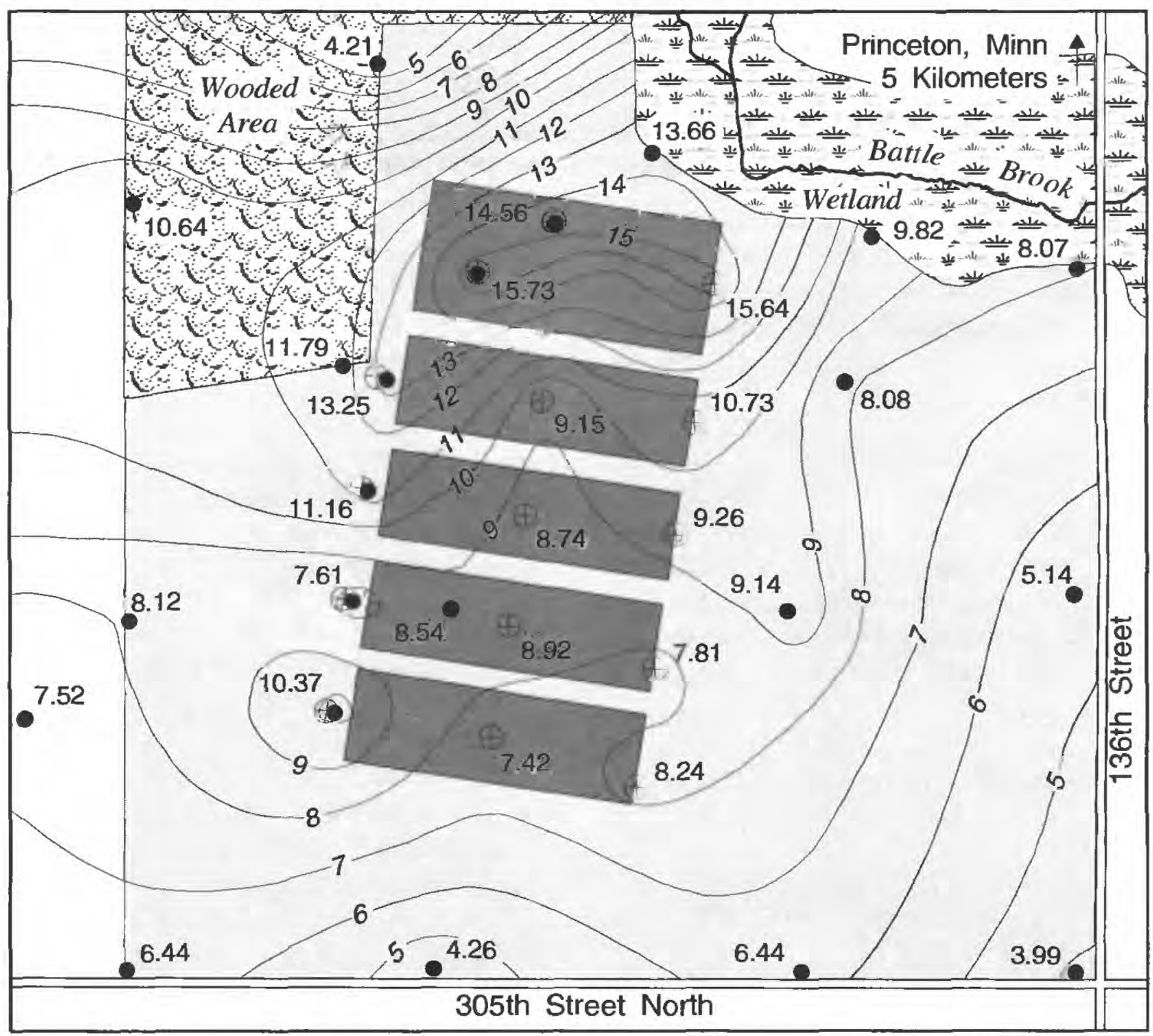

Base from U.S. Geological Survey Princeton 1:24,000 quadrangle, 1982

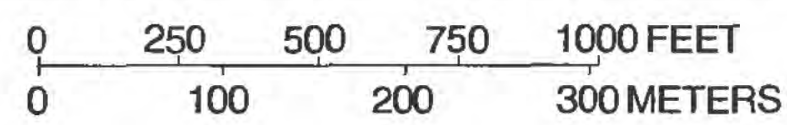

EXPLANATION

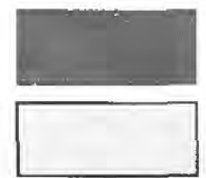

Cropped area

Research area, including cropped areas

- 7- Line of equal thickness--

Contour interval 1 meter

6.44 Observation well--Number indicates saturated thickness of surficial aquifer in meters

$\oplus^{9.26}$ Multiport well--Number indicates saturated thickness of surficial aquifer in meters

The research area is located in the northeast quarter of section 18, township $\mathrm{T} 35 \mathrm{~N}$, range $\mathrm{R} 26 \mathrm{~W}$ 
Table 4.--Estimated horizontal saturated hydraulic conductivity of the surficial aquifer at the Princeton, Minnesota Management Systems Evaluation Area

[units, centimeters per second; $m$, meters; bls, below land surface; number of analyses in parentheses; na, not applicable; MPORT, multiport well]

\begin{tabular}{|c|c|c|c|c|c|}
\hline Type of Analysis & Mean & Median & $\begin{array}{l}\text { Standard } \\
\text { Deviation }\end{array}$ & Minimum & Maximum \\
\hline $\begin{array}{c}\text { Laboratory analyses }{ }^{1}, \\
0-1.0 \mathrm{~m} \text { bls, } \\
\text { upland area (7) }\end{array}$ & 0.0024 & 0.0042 & 0.0021 & 0.0004 & 0.0055 \\
\hline $\begin{array}{l}1.01-2.0 \mathrm{~m} \mathrm{bls} \text {, } \\
\text { upland area }(8)\end{array}$ & .0042 & .0042 & .0018 & .0017 & .0064 \\
\hline $\begin{array}{l}2.01-4.0 \mathrm{~m} \mathrm{bls} \text {, } \\
\text { upland area (3) }\end{array}$ & .0035 & .0032 & .0011 & .0025 & .0047 \\
\hline $\begin{array}{c}0-1.0 \mathrm{~m} \mathrm{bls} \text {, } \\
\text { lowland area (6) }\end{array}$ & .0031 & .0032 & .0010 & .0018 & .0043 \\
\hline $\begin{array}{l}1.01-2.0 \mathrm{~m} \mathrm{bls} \\
\text { lowland area }(6)\end{array}$ & .0125 & .0129 & .0070 & .0037 & .0228 \\
\hline $\begin{array}{c}\text { All laboratory analyses, } \\
0-2.0 \mathrm{~m} \text { bls (34) }\end{array}$ & .0052 & .0042 & .0046 & .0004 & .0228 \\
\hline $\begin{array}{c}\text { Hazen formula and } \\
\text { particle-size analyses, } \\
0-1.0 \mathrm{~m} \text { bls, } \\
\text { upland area (27) }\end{array}$ & .0074 & .0070 & .0022 & .0010 & .0120 \\
\hline $\begin{array}{l}1.01-2.0 \mathrm{~m} \mathrm{bls} \text {, } \\
\text { upland area (16) }\end{array}$ & .0101 & .0090 & .0038 & .0060 & .0220 \\
\hline $\begin{array}{c}0-1.0 \mathrm{~m} \mathrm{bls} \text {, } \\
\text { lowland area (56) }\end{array}$ & .0067 & .0060 & .0023 & .0002 & .0130 \\
\hline $\begin{array}{l}1.01-2.0 \mathrm{~m} \mathrm{bls} \\
\text { lowland area (39) }\end{array}$ & .0254 & .0170 & .0301 & .0070 & .1860 \\
\hline $\begin{array}{l}\text { All Hazen formula and } \\
\text { particle-size analyses, } \\
0-2.0 \mathrm{~m} \text { bls (138) }\end{array}$ & .0125 & .0080 & .0179 & .0002 & .1860 \\
\hline $\begin{array}{l}\text { Chloride time of travel } \\
\text { from MPORT A800 to } \\
\text { MPORT A880 (1) }\end{array}$ & .0655 & na & na & .042 & .089 \\
\hline Slug tests (47) & .0550 & .0520 & .0270 & .0120 & .0970 \\
\hline Aquifer test (1) & .2820 & na & na & na & na \\
\hline
\end{tabular}

${ }^{1}$ Results of laboratory analyses from H.W. Olsen, U.S. Geological Survey-Geologic Division, Golden, Colorado, written commun., 1993 
Bouwer and Rice method may not be entirely valid for wells with screens as short as $15 \mathrm{~cm}$. The hydraulic conductivity of the sandy peat on the edge of the wetland is $1.4 \times 10^{-3} \mathrm{~cm} / \mathrm{s}$, based on four slug-tests conducted on wells MC33 and MC34 (fig. 4).

Results of the aquifer test indicate that the hydraulic conductivity of the surficial aquifer is about $2.82 \times 10^{-1}$ $\mathrm{cm} / \mathrm{s}$ (table 4) and that the storage coefficient is about 0.02 . Logarithmic plots of drawdown(s) versus $t / \mathrm{r}^{2}$ coincided closely with the Theis curve. Accuracy of the aquifer-test results was limited by a low pumping rate (1.6 $\mathrm{L} / \mathrm{s}$ ), variable pump discharge (between 1.26 and 1.89 $\mathrm{L} / \mathrm{s}$ ), short duration of the test (840 minutes), and small drawdown in the observation wells (maximum of $7.5 \mathrm{~cm}$ at a radial distance of $3.1 \mathrm{~m}$ from the pumped well). Pump discharge varied from $1.8 \mathrm{~L} / \mathrm{s}$ to $1.3 \mathrm{~L} / \mathrm{s}$ every 5 to 7 seconds. Maximum drawdown in the observation wells varied from $2.3 \mathrm{~cm}$, at a radial distance of $32 \mathrm{~m}$ from the pumped well, to $7.5 \mathrm{~cm}$, at a radial distance of $3.1 \mathrm{~m}$ from the pumped well. The maximum drawdown in the pumped well was about $2.0 \mathrm{~m}$.

Estimates of the saturated horizontal hydraulic conductivity for the surficial aquifer using the five different methods agree within about two orders of magnitude (table 4). These data agree favorably with the mean saturated horizontal hydraulic conductivity in the Anoka Sand Plain of $0.12 \mathrm{~cm} / \mathrm{s}$, based on 9 aquifer tests conducted by Lindholm $(1980$, p. 21$)$. The lowest hydraulic conductivities were obtained using laboratory analyses (median of $0.0042 \mathrm{~cm} / \mathrm{s}$ ) and the greatest estimate was obtained based on results of the aquifer test $(0.2820 \mathrm{~cm} / \mathrm{s})$. The lower hydraulic conductivities are primarily the result of fine to medium sand in the unsatured zone compared to results of the other analyses which were completed on medium to coarse sand in the saturated zone (fig. 9). These differences are also due to differences in the volume of aquifer being tested by each method: laboratory and particle-size analyses tested $2.5 \times 10^{-5} \mathrm{~m}^{3}$ or less; slug tests tested $3.7 \times 10^{-3} \mathrm{~m}^{3}$; chloride time-of-travel calculation tested $24 \mathrm{~m}^{3}$; and the aquifer test tested $1.6 \times 10^{5} \mathrm{~m}^{3}$. Results from the aquifer test are considered less reliable than the other methods due to uncertainties in the test conditions, discussed earlier. Of the four remaining methods, the estimate of hydraulic conductivity based on chloride time of travel is considered most accurate and representative of the surficial aquifer in the research area because this method tested the largest volume of aquifer.

\section{Ground-Water Recharge}

Precipitation is the principal source of recharge to the ground-water system. Most ground-water recharge occurs from about late March through May causing the water table to rise (fig. 8). Recharge occasionally occurs during the fall or summer, depending on rainfall, antecedent soil moisture, and evapotranspiration. Recharge rates vary across the research area due to the effects of increased recharge in lowland areas compared to upland areas (fig. 5) (Delin and Landon, in press). As a result of this variable recharge, the rise in the water table was not uniform across the research area and an irregular water-table configuration formed during March through May 1991 (fig. 14) compared to other times during the year (figs. 4 and 15).

Ground-water recharge to the surficial aquifer during 1991-92 was estimated for the 15 wells listed in table 5 using the method of hydrograph analysis and a specific yield of 0.3 . Ground-water recharge was lower during 1992 than during 1991 (table 5) because precipitation during 1991 (94.5 cm) at Santiago, Minnesota was 16.7 $\mathrm{cm}$ greater than the 30-year average of $77.8 \mathrm{~cm}$ (U.S. Department of Commerce, 1961-92). By comparison, precipitation during $1992(58.5 \mathrm{~cm})$ was $19.3 \mathrm{~cm}$ less than the 30-year average. Recharge during 1991 was about 35 percent smaller near Battle Brook (wells MC2, MC22, $\mathrm{MC} 33$, and MC34) than elsewhere in the research area. These smaller recharge rates may have resulted in part from the hydraulic interconnection of the surficial aquifer and Battle Brook. Because the stage of Battle Brook remains relatively constant throughout the year, the apparent recharge rates near the Brook may have been reduced compared to wells at greater distances from the Brook. Based on results of this study, estimates of recharge using hydrograph analysis are less accurate for rates between 5 and $10 \mathrm{~cm} / \mathrm{yr}$ than for rates between 10 and $25 \mathrm{~cm} / \mathrm{yr}$.

\section{Ground-Water Flow}

Because of spatially-variable recharge, the direction and velocity of ground-water flow in the surficial aquifer varied seasonally throughout the research area (figs. 4, 14, and 15). Horizontal ground-water flow is generally from west to east across the research area (fig. 4). From about November through March of each year (winter), groundwater flows from an area of higher hydraulic head west of the research area toward Battle Brook, which forms a natural discharge boundary (fig. 4). A divide in the water table nearly bisects the research area, separating flow to the south and flow to the north (figs. 4 and 15). This divide is evident in figure 11 as a slight rise in the water table between wells B400 and C400. Variable ground-water recharge during April through May of 1991 (spring) resulted in variable ground-water-flow directions (fig. 14). From about June through October (summer), ground-water-flow directions stabilized (fig. 15) into a 


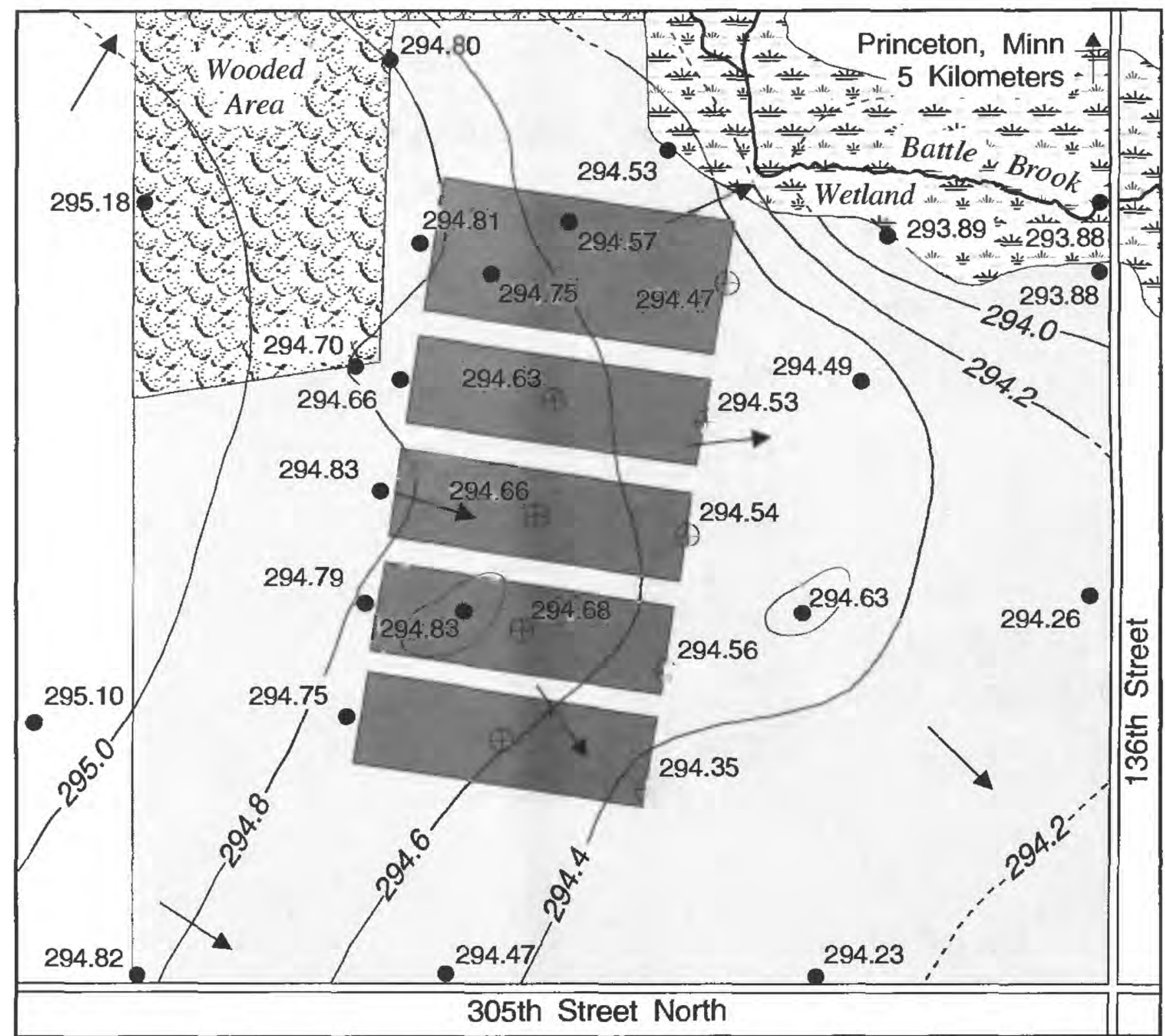

Base from U.S. Geological Survey

Princeton 1:24,000 quadrangle, 1982

$\begin{array}{ccccc}q & 250 & 500 & 750 & 1000 \text { FEET } \\ 0 & 100 & 200 & 300 \text { METERS }\end{array}$

EXPLANATION

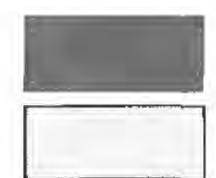

Cropped area

Research area, including cropped areas

-294.6 - Water-table contour--Dashed where approximate. Contour interval 0.2 meters. Datum is sea level

$\longrightarrow$ Direction of ground-water flow

294.82. Observation well--Number indicates water-table altitude in meters above sea level

$294.63_{\oplus} \quad$ Multiport well--Number indicates water-table altitude in meters above sea level

The research area is located in the northeast quarter of section 18, township $\mathrm{T} 35 \mathrm{~N}$, range $\mathrm{R} 26 \mathrm{~W}$

Figure 14.--Water-table configuration at the Princeton, Minnesota Management Systems Evaluation Area, May 1991. 


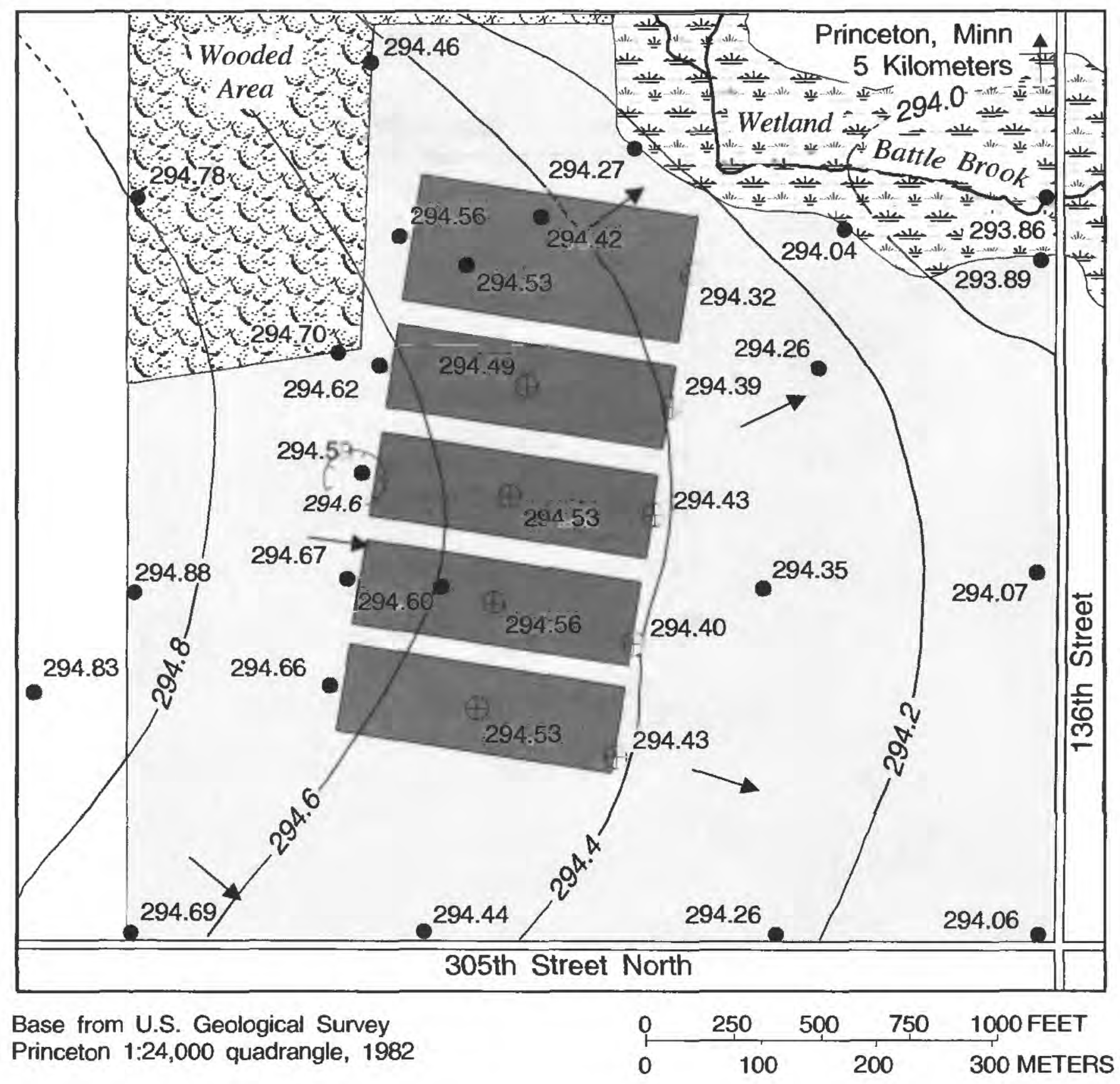

EXPLANATION

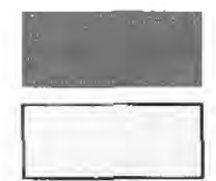

Cropped area

Research area, including cropped areas

-294.6- Water-table contour--Dashed where approximate. Hachures indicate depression. Contour interval 0.2 meters. Datum is sea level

$\longrightarrow$ Direction of ground-water flow

294.06 Observation well--Number indicates water-table altitude in meters above sea level

294.49 Multiport well--Number indicates water-table altitude in meters above sea level

The research area is located in the northeast quarter of section 18 , township $\mathrm{T} 35 \mathrm{~N}$, range $\mathrm{R} 26 \mathrm{~W}$

Figure 15.--Water-table configuration at the Princeton, Minnesota Management Systems Evaluation Area, August 1991. 
Table 5.--Estimated ground-water recharge to the surficial aquifer at the Princeton, Minnesota Management Systems Evaluation Area,1991-92 [in centimeters per year]

\begin{tabular}{lccc}
\hline & $\begin{array}{c}\text { Well Number } \\
\text { (figure 6) }\end{array}$ & 1991 & 1992 \\
\hline MC1 & 20.9 & 5.4 \\
MC2 & 14.7 & 7.8 \\
MC3 & 22.1 & 11.7 \\
MC10 & 25.3 & 8.1 \\
MC11 & 24.7 & 13.1 \\
MC15 & 23.9 & 13.2 \\
MC17 & 22.7 & 11.4 \\
MC19 & 20.5 & 12.4 \\
MC22 & 18.1 & 5.7 \\
MC26 & 23.3 & 6.7 \\
MC27 & 22.5 & 5.3 \\
MC28 & 23.6 & 9.5 \\
MC29 & & 25.7 & 8.8 \\
MC33 & 15.2 & 4.9 \\
MC34 & 11.7 & 9.2 \\
\hline & Mean & 21.0 & 8.9 \\
Standard Deviation & 4.2 & 2.9 \\
\hline
\end{tabular}

configuration that was similar to the flow directions observed during the winter months (fig. 4). However, the water table was higher following spring recharge, compared to other times during the year, and the stage of Battle Brook remained relatively constant throughout the remainder of the year. Therefore, ground-water-flow directions in the northern third of the study area shifted to the north from about June through October (fig. 15) compared to other times during the year (figs. 4 and 15).

During 1991, horizontal hydraulic gradients ranged from 0.0009 to 0.002 and ground-water velocities ranged from 5 to $18 \mathrm{~cm}$ per day. Hydraulic gradients and groundwater velocities were greatest during the spring and summer months and generally were greatest near Battle Brook. These variations are evident in the ground-waterflow paths calculated using equations (1) and (2). Calculated ground-water-flow paths from the 800-series MPORTs to the 880-series MPORTs for cropped areas A, $\mathrm{C}$, and $\mathrm{E}$ (figs. 7a, 7b, and 7c) illustrate the variability in direction and velocity of ground-water flow from south to north across the research area. Flow paths in the southern half of the research area had a southerly trend while those in the northern half of the research area had a northerly trend. The horizontal distance of ground-water flow during 1991 for the five flow paths ranged from 25 to 32 meters per year $(\mathrm{m} / \mathrm{yr})$ with an average of $28 \mathrm{~m} / \mathrm{yr}$.

Although horizontal flow predominates in the surficial aquifer, hydraulic head generally decreases with depth. During April-August 1994 at location R1, for example, the head at the base of the surficial aquifer ( $14 \mathrm{~m}$ below the water table) was an average of $1.5 \mathrm{~cm}$ less than the head at the water table. Thus, the average downward hydraulic gradient was about 0.001. Near Battle Brook, the hydraulic head increases with depth and flow is upward. During August 1994 at location MC33, for example, the head at the base of the surficial aquifer 
( $8.5 \mathrm{~m}$ below the water table) was $1.5 \mathrm{~cm}$ greater than the head at the water table. Thus, the upward hydraulic gradient near Battle Brook was about 0.002 .

\section{Till}

Beneath the surficial aquifer is a reddish-brown, poorly sorted, clayey, sandy till deposited by the Superior lobe (figs. 9, 10, and 11). This till is about $15 \mathrm{~m}$ thick and hydraulically separates the surficial aquifer and the underlying confined-drift aquifer (fig. 9). The till is present throughout the study area and contains layers of sand and gravel that are 0.1 to $2.0 \mathrm{~m}$ thick. The top of the till surface, and base of the surficial aquifer, generally slopes from the south toward a northeast-southwest trending valley beneath cropped area $\mathrm{E}$ (fig. 16).

\section{Confined-Drift Aquifer}

A confined-drift aquifer composed of coarse to very coarse, dark grayish-brown sand to very fine gravel underlies the till (fig. 9). The aquifer is about $3 \mathrm{~m}$ thick and consists of about 30 percent very fine gravel, 40 percent very coarse sand, 10 percent coarse sand, and 20 percent finer material (Thein Well Co., written commun., 1991). The saturated hydraulic conductivity of the confined-drift aquifer was estimated to be about 0.18 $\mathrm{cm} / \mathrm{s}$, based on particle-size analyses and calculations using the Hazen formula. Based on a saturated thickness of $3 \mathrm{~m}$, transmissivity of the confined-drift aquifer is about $466 \mathrm{~m}^{2} / \mathrm{d}$. The irrigation well (fig. 6) is completed in this aquifer and yields about 38 liters per second.

\section{Mount Simon-Hinckley Aquifer}

The Mount Simon-Hinckley bedrock aquifer underlies the confined-drift aquifer in the research area (fig. 9). It is a fine to coarse grained grayish-brown sandstone containing interbedded siltstone and shale. Based on regional data, the Mount Simon-Hinckley bedrock aquifer is about $30 \mathrm{~m}$ thick in the research area and the hydraulic conductivity is about $0.007 \mathrm{~cm} / \mathrm{s}$ (Woodward, 1986).

\section{WATER QUALITY}

Ground-water quality of the surficial aquifer in the study area is described in the following sections of the report for four land-use and geographic settings (field, upgradient, wetland, and off-site) (fig. 17). Water quality in the deeper aquifers and Battle Brook is compared to water quality in the surficial aquifer. Water quality in the study area is also compared to water quality in the Anoka Sand Plain, based on results of previous water-quality studies. Because water that recharges the surficial aquifer moves through the soil/root zone, a description of the soil chemistry is included at the beginning of the sections describing the inorganic and organic constituents.

\section{Inorganic Constituents}

Soil samples collected during April 1991 to a depth of $15 \mathrm{~cm}$ below land surface were analyzed for organicmatter content and $\mathrm{pH}$ and for concentrations of the nutrients phosphorus, potassium, sulfur, and zinc (table 6). These nutrients are of primary interest for crop production in sandy soils (Rosen and Munter, 1992; Rehm and others, 1993). The pH values were 6.8 and 6.9 in cropped areas A and B, respectively, on the south side of the research area, and decreased to 6.1 in cropped area $\mathrm{E}$, on the north side of the research area. These $\mathrm{pH}$ values are adequate for corn, soybean, potato, and sweet com production (Rosen and Munter, 1992). Based on the relatively high $\mathrm{pH}$ values, it is likely that lime was applied to the alfalfa crop grown on the research area during 1981 through 1989. Lime is applied to legumes like alfalfa to raise the $\mathrm{pH}$ above 6.0 , thus providing an ideal environment for bacterial growth (Rehm and others, 1992). Soils in the research area have the relatively high concentrations of phosphorus and low concentrations of potassium, sulfur, and zinc required for adequate plant growth (Rehm and others, 1993; Rosen and Munter, 1992). These concentrations are typical for soils in the Anoka Sand Plain.

\section{Nitrogen Species and Chloride}

Effects of previous land use on the research area and on upgradient areas were evident based on results of groundwater-quality analyses of samples collected during April 1991. Concentrations of nitrate nitrogen (nitrate- $N$ ) in 4 of the 7 field wells equaled or exceeded the USEPA Maximum Contaminant Level (MCL) of $10 \mathrm{mg} / \mathrm{L}$ (U.S. Environmental Protection Agency, 1991).

Concentrations of nitrate- $\mathrm{N}$ in ground water from the field wells ranged from 2.1 to $23 \mathrm{mg} / \mathrm{L}$ (fig. 17) with a median concentration of $10 \mathrm{mg} / \mathrm{L}$ (fig. 18) (Delin and others, 1994, table 2). The median concentration of nitrate- $\mathrm{N}$ in the field wells exceeded the median in the upgradient wells $(2.1 \mathrm{mg} / \mathrm{L})$, wetland wells $(3.4 \mathrm{mg} / \mathrm{L})$, and in the offsite wells ( $4.8 \mathrm{mg} / \mathrm{L}$ ) (fig. 18).

Concentrations of nitrate- $\mathrm{N}$ less than $0.2 \mathrm{mg} / \mathrm{L}$ were detected in three of the six upgradient wells (MC2, MC3, and MC15) (fig. 17). These relatively low concentrations of nitrate- $\mathrm{N}$ were present in ground water that likely was recharged in adjacent wooded areas. Concentrations of nitrate-N in ground water from well MC17 $(15 \mathrm{mg} / \mathrm{L})$ exceeded the MCL of $10 \mathrm{mg} / \mathrm{L}$ (fig. 17). This relatively high concentration of nitrate- $\mathrm{N}$ likely resulted from applications of nitrogen fertilizer to a field located immediately west (upgradient) of the well. 


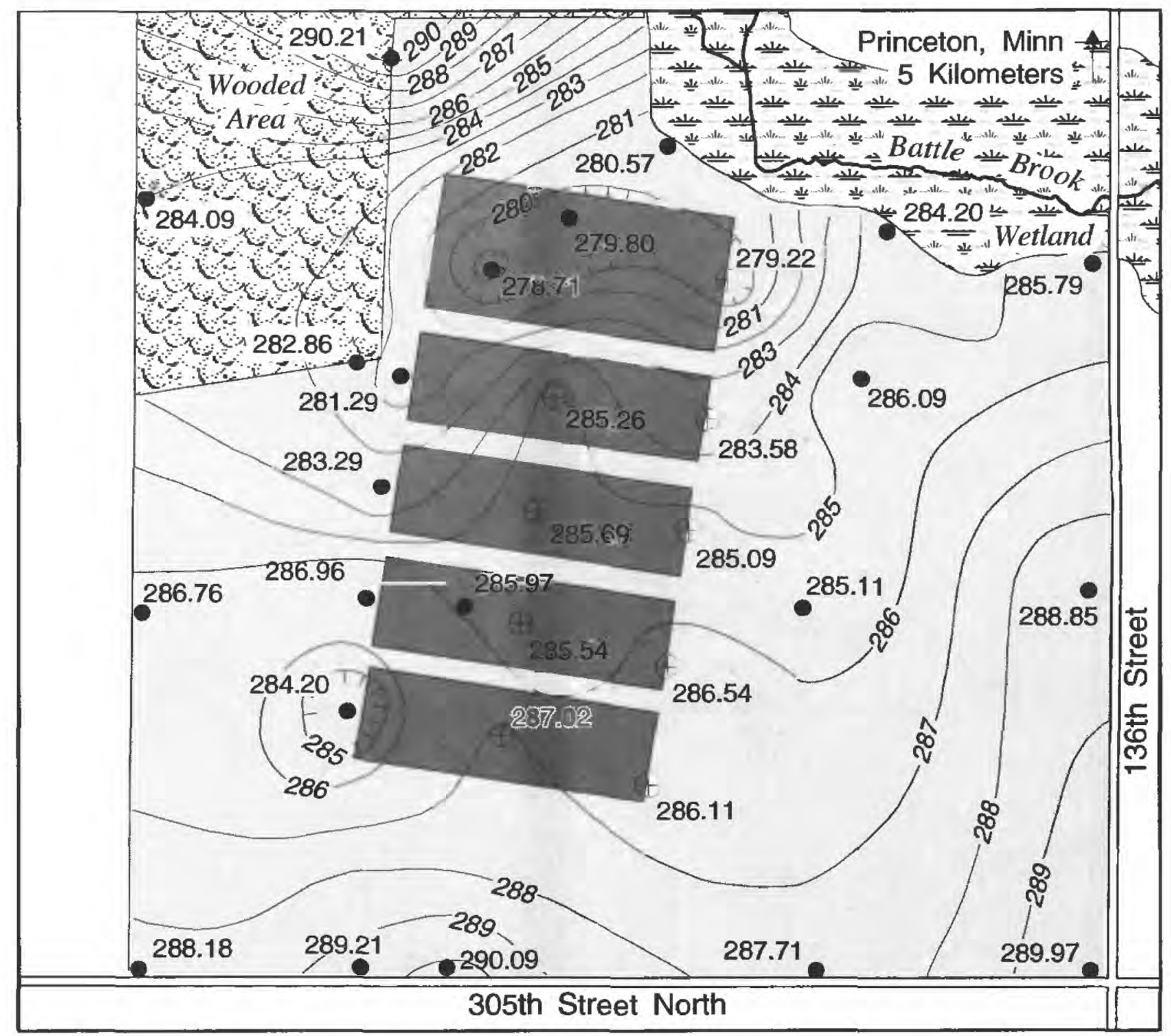

\section{EXPLANATION}

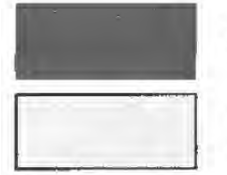

Cropped area

Research area, including cropped area

- 287- Structure contour--Shows altitude of base of surficial aquifer.

Contour interval 1 meter.

Datum is sea level

287.71 Observation well--Number indicates altitude of base of surficial aquifer in meters above sea level

287.02

$\oplus \quad$ Multiport well--Number indicates altitude of base of surficial aquifer in meters above sea level

The research area is located in the northeast quarter of section 18, township $\mathrm{T} 35 \mathrm{~N}$, range $\mathrm{R} 26 \mathrm{~W}$

Figure 16.--Configuration of base of surficial aquifer at the Princeton, Minnesota Management Systems Evaluation Area. 


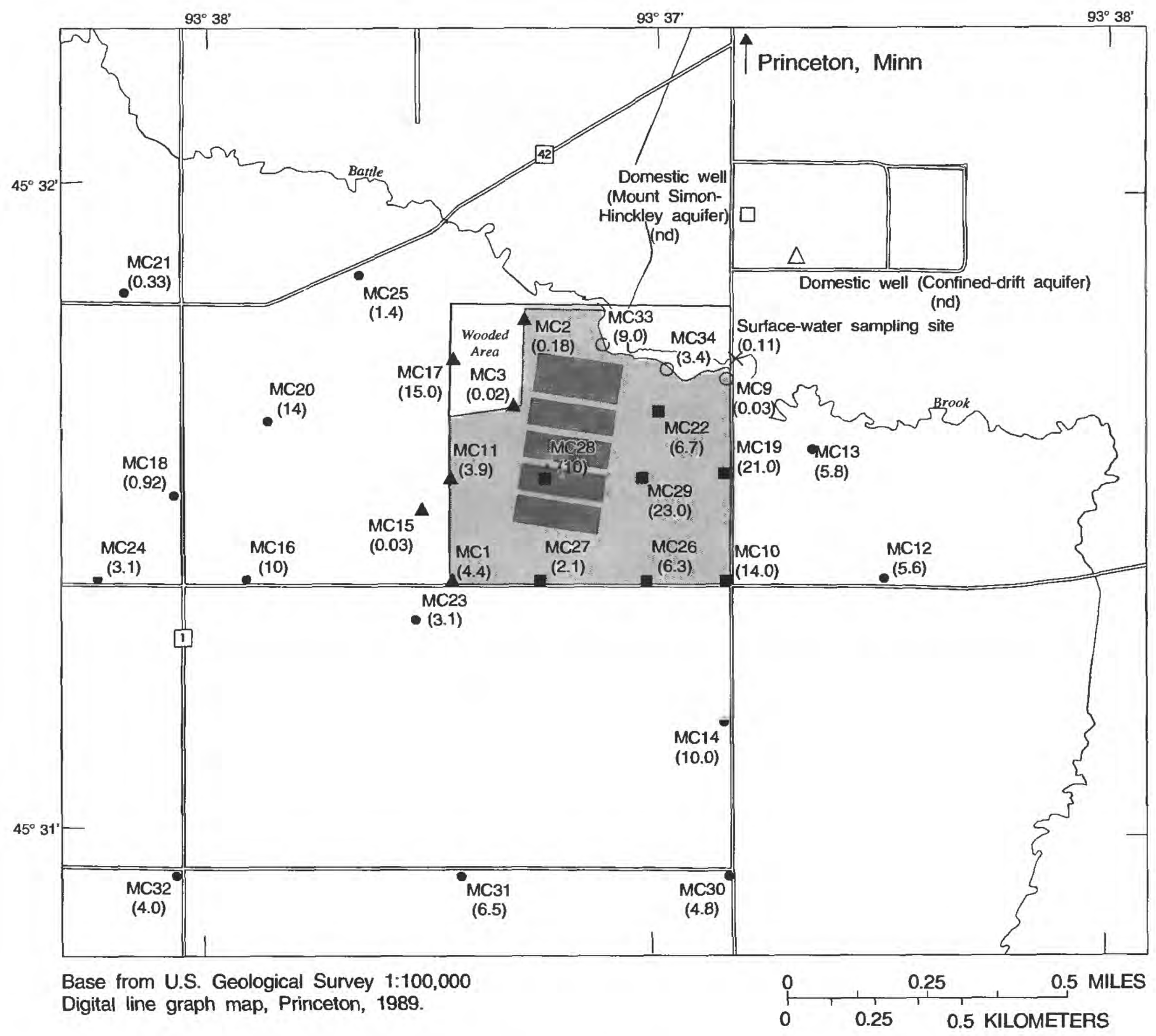

EXPLANATION

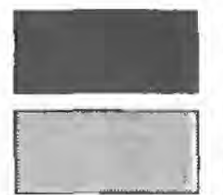

Cropped area

Research area, including cropped areas

Observation wells completed in the surficial aquifer at or near the water table-Number in parentheses indicates concentration of nitrate nitrogen in milligrams per liter
${ }^{M C 23}$ Field well and identifier
MC11 U.9) Upgradient well and identifier
(3.9)
MC34
$M C 13$
(5.8) Off-site well and identifier
nd No detection above the detection limit of 0.01 milligrams per liter

Figure 17.--Concentrations of nitrate nitrogen in the study area, April 1991. 
Table 6.--Mean concentration of organic matter, $\mathrm{pH}$, and nutrients in soil samples collected during April 1991 at the Princeton, Minnesota Management Systems Evaluation Area [ppm, parts permillion]

\begin{tabular}{lcccccc}
\hline $\begin{array}{c}\text { Cropped Area } \\
\text { (figure 6) }\end{array}$ & $\begin{array}{c}\text { Organic } \\
\text { matter } \\
\text { (percent) }\end{array}$ & $\begin{array}{c}\mathrm{pH} \\
\text { (units) }\end{array}$ & $\begin{array}{c}\text { Phosphorus } \\
(\mathrm{ppm})\end{array}$ & $\begin{array}{c}\text { Potassium } \\
(\mathrm{ppm})\end{array}$ & $\begin{array}{c}\text { Sulfur } \\
(\mathrm{ppm})\end{array}$ & $\begin{array}{c}\text { Zinc } \\
\text { (ppm) }\end{array}$ \\
\hline $\mathrm{A}$ & 0.8 & 6.8 & 37 & 87 & 2 & 0.3 \\
$\mathrm{~B}$ & .8 & 6.9 & 29 & 73 & 1 & .3 \\
$\mathrm{C}$ & .8 & 6.4 & 41 & 94 & 1 & .3 \\
$\mathrm{D}$ & 1.0 & 6.3 & 38 & 142 & 3 & .5 \\
$\mathrm{E}$ & .9 & 6.1 & 31 & 105 & 1 & .3 \\
\hline \hline Mean & .9 & 6.5 & 35 & 100 & 1.6 & .3 \\
\hline
\end{tabular}

Concentrations of nitrate- $\mathrm{N}$ in the three wetland wells (MC9, MC33, and MC34) ranged from 0.03 to $9.0 \mathrm{mg} / \mathrm{L}$ with a median of $3.4 \mathrm{mg} / \mathrm{L}$ (figs. 17 and 18). Because ground-water flow is from the research area toward these wells and Battle Brook (figs. 14 and 15), ground water from the wetland wells should be influenced by agricultural activity on the research area. However, the finer textured, organic-rich soils near the wetland may result in biochemical conditions that attenuate nitrate- $\mathrm{N}$ in the ground water locally (Hamilton and others, 1993). Based on data collected during April 1991, however, concentrations of nitrate- $\mathrm{N}$ in ground water near the wetland cannot be conclusively identified as biochemically altered relative to concentrations in the research area.

Concentrations of nitrate- $\mathrm{N}$ in the 13 off-site wells ranged from 0.33 to $14 \mathrm{mg} / \mathrm{L}$ with a median concentration of $4.8 \mathrm{mg} / \mathrm{L}$ (figs. 17 and 18). Concentrations of nitrate$\mathrm{N}$ in ground water for off-site wells $\mathrm{MC14}, \mathrm{MC16}$, and MC20 equaled or exceeded the MCL of $10 \mathrm{mg} / \mathrm{L}$ (fig. 17). Each of these wells was located adjacent to an agricultural field. However, not all ground water in off-site wells adjacent to areas of agricultural land use had concentrations of nitrate- $\mathrm{N}$ at or near the $\mathrm{MCL}$. Land use near most off-site wells to the west and south of the research area was mixed, being either agricultural, wooded, or residential. Thus, interpretation of the relationship between water quality and land use in these areas was difficult. The mixed land use and slightly greater sampling depth below' the water table for the offsite wells (Delin and others, 1994, table 2) may explain why concentrations of nitrate- $\mathrm{N}$ in the off-site wells were less than in the field wells (figs. 17 and 18).

Concentrations of nitrate- $\mathrm{N}$ were below the detection limit of $0.02 \mathrm{mg} / \mathrm{L}$ in the domestic wells screened in the confined-drift and Mount Simon-Hinckley aquifers. The concentration of nitrate- $\mathrm{N}$ from Battle Brook, at the northeast corner of the research area, was $0.11 \mathrm{mg} / \mathrm{L}$, less than for most of the ground-water samples in the study area (fig. 17).

Concentrations of total kjeldahl nitrogen (organic nitrogen + ammonium nitrogen) in upgradient wells MC3 and MC15 were 0.38 and $0.21 \mathrm{mg} / \mathrm{L}$, respectively (Delin and others, 1994, table 2). Concentrations of ammonium nitrogen and nitrite nitrogen in the upgradient wells were below the detection limit of $0.02 \mathrm{mg} / \mathrm{L}$. Therefore, the predominant nitrogen species beneath these upgradient wooded areas was organic nitrogen.

Of all the wells completed in the surficial aquifer, ammonium nitrogen was only detected in the wetland wells at concentrations between $0.06 \mathrm{mg} / \mathrm{L}$ and the detection limit of $0.02 \mathrm{mg} / \mathrm{L}$ (Delin and others, 1994, table 2). Ammonium nitrogen was detected at concentrations of 0.03 and $0.12 \mathrm{mg} / \mathrm{L}$ in the confined-drift and Mount Simon-Hinckley aquifers, respectively (Delin and others, 1994, table 2). Total kjeldahl nitrogen was also detected in both of the deeper aquifers at a concentration of $0.24 \mathrm{mg} / \mathrm{L}$. Organic nitrogen was the predominant nitrogen species present in these deeper aquifers. 


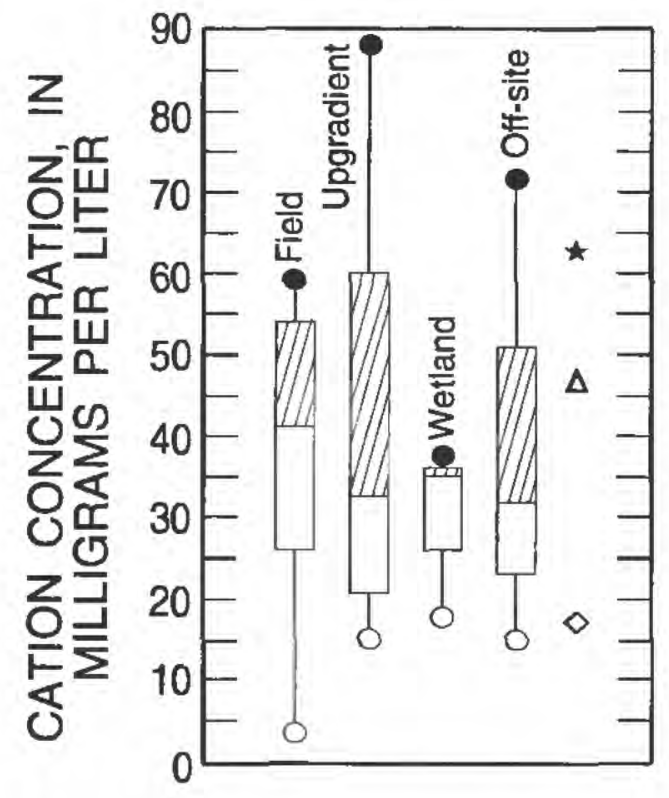

Calcium

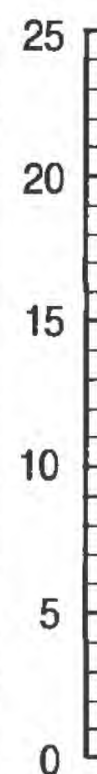

Magnesium

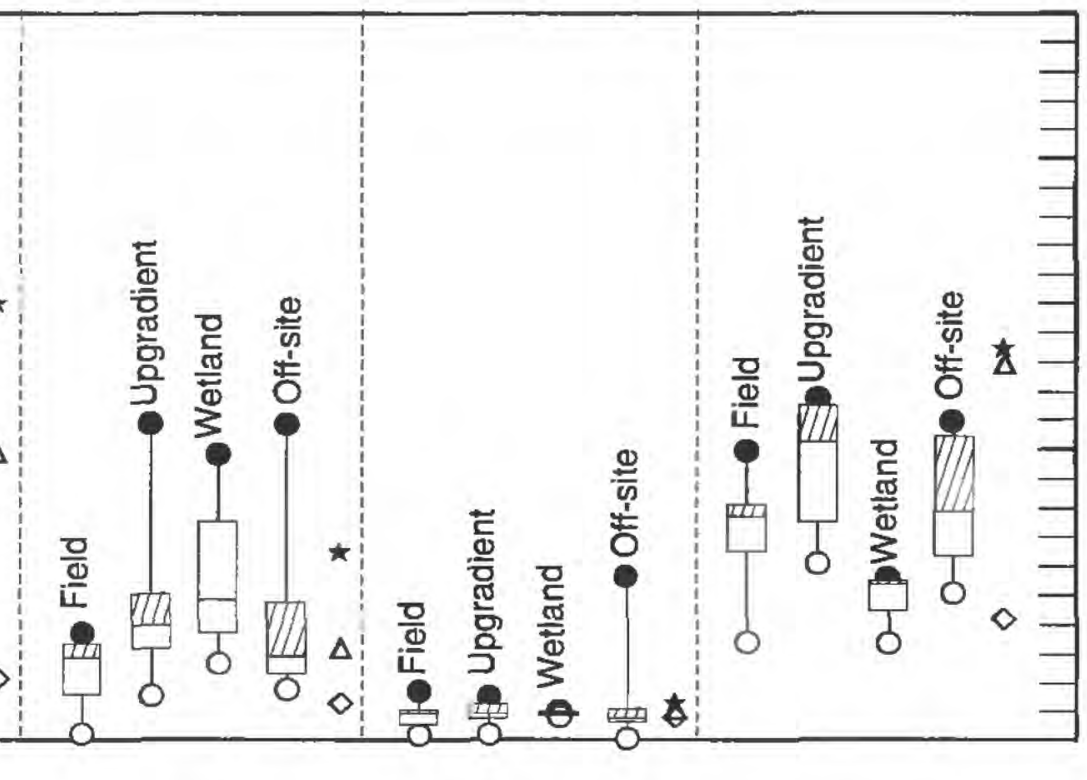

Sodium

Potassium

Silica

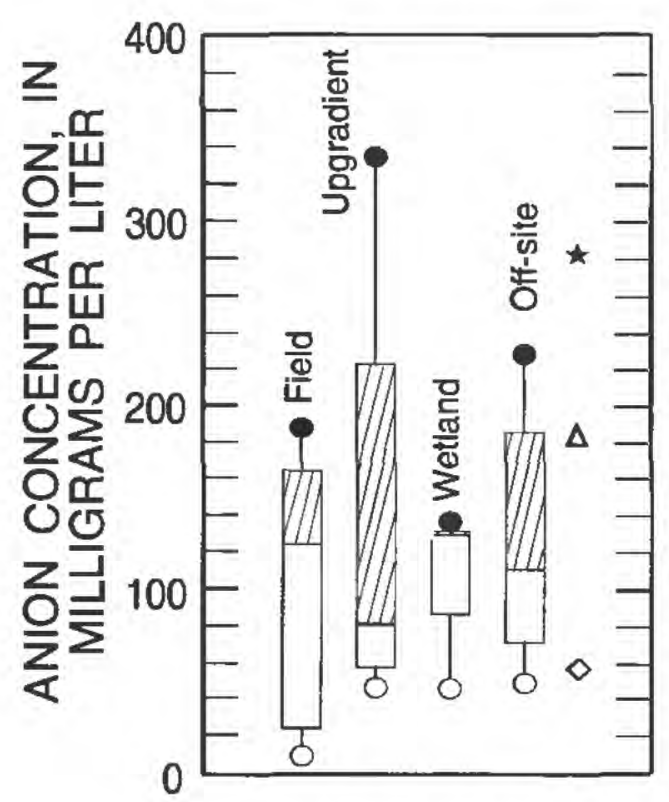

Bicarbonate

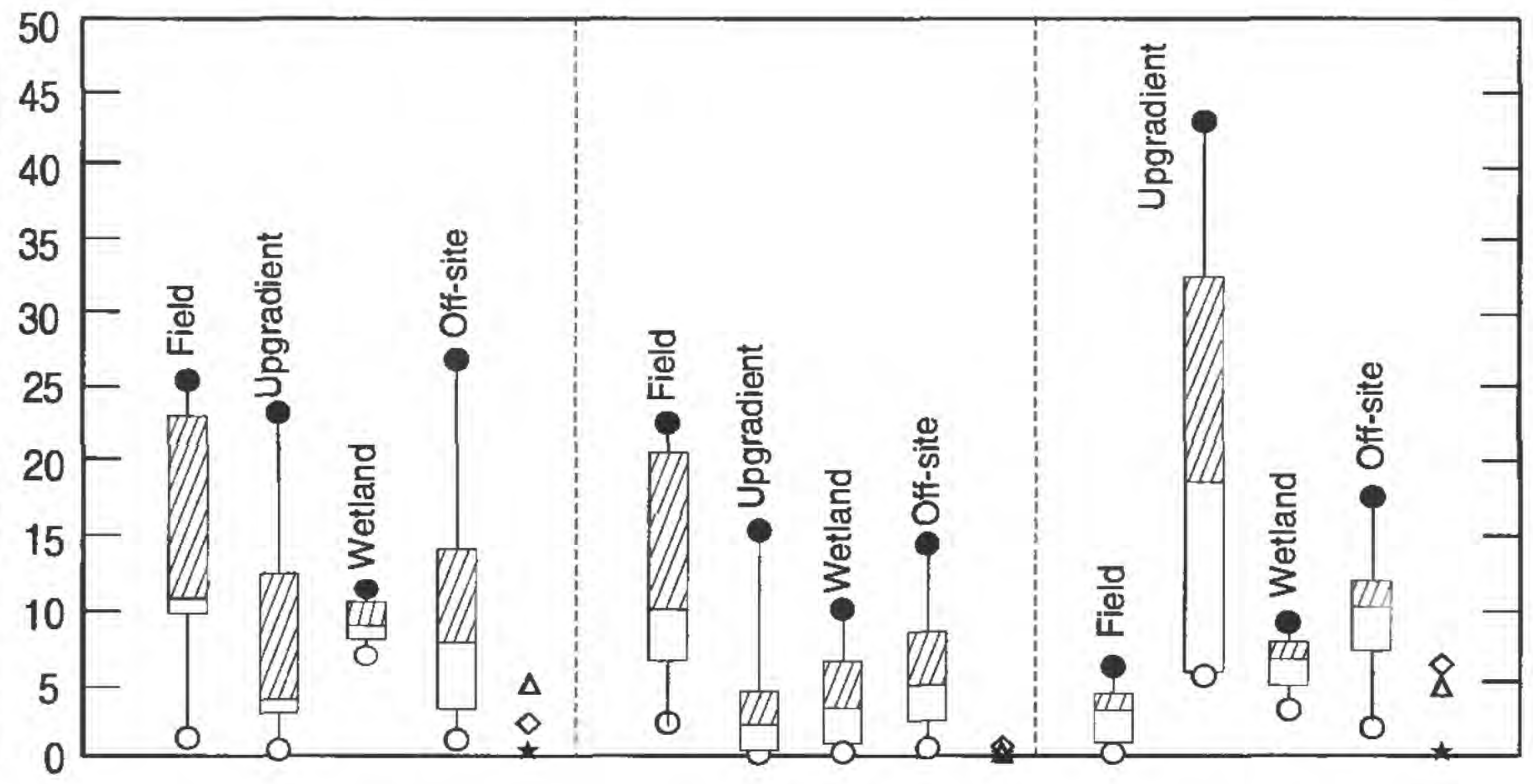

Chloride

Sulfate
Nitrate

Nitrogen

\section{EXPLANATION}

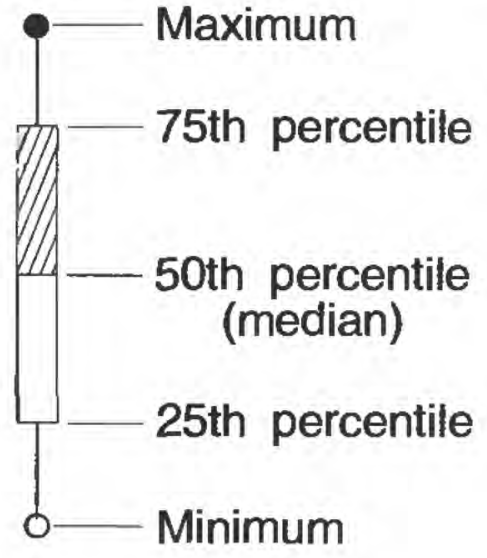

$\diamond$ Battle Brook

* Mount Simon aquifer

$\Delta$ Confined-drift aquifer

\section{Number of wells included \\ in the analysis in each grouping of wells}

7 Field wells

6 Upgradient wells

3 Wetland wells

13 Off-site wells

Figure 18.-Statistical distribution of selected cations and anions in the study area, April 1991. 
The concentration of total kjeldahl nitrogen was 0.47 $\mathrm{mg} / \mathrm{L}$ in Battle Brook, the highest value within the study area (Delin and others, 1994, table 2). Ammonium nitrogen and nitrite nitrogen were both absent in Battle Brook, with organic nitrogen being the dominant nitrogen species.

The median concentration of chloride in the field wells $(11 \mathrm{mg} / \mathrm{L})$ exceeded the median in the upgradient wells $(3.8 \mathrm{mg} / \mathrm{L})$, wetland wells $(9.2 \mathrm{mg} / \mathrm{L})$, and in the off-site wells $(7.7 \mathrm{mg} / \mathrm{L})$, similar to concentrations of nitrate- $N$ (fig. 18) (Delin and others, 1994, table 2). Statistical analyses indicate a significant correlation between concentrations of chloride and nitrate- $\mathrm{N}$ in the field wells (Pearson correlation coefficient ( $\mathrm{r}$ ) of 0.79 with a level of significance (p) of 0.033 ). Concentrations of chloride in two of the upgradient wells in wooded areas (wells MC2 and MC15) were less than $5 \mathrm{mg} / \mathrm{L}$, which is less than the median chloride concentration of $11 \mathrm{mg} / \mathrm{L}$ in the field wells. The concentrations of chloride were 5.3 and 0.5 $\mathrm{mg} / \mathrm{L}$ in the confined-drift and Mount Simon-Hinckley aquifers, respectively.

Chloride and nitrate- $\mathrm{N}$ accounted for greater than 50 percent of the total anions present in three of the seven field wells, as shown in the trilinear diagram in figure 19. Of the seven field wells, three had water of the calciumbicarbonate type, three had water of mixed calciumbicarbonate-chloride-nitrate-N type, and one had water of the calcium-nitrate- $\mathrm{N}$-chloride type. Other ground water from the study area was predominantly of the calciumbicarbonate type. The relative proportions of the major cations did not differ significantly in ground-water samples collected in the study area (fig. 19).

\section{Source of Nitrate Nitrogen and Chloride in the}

\section{Research Areg}

The on-site detections of nitrate-Nand chloride during April 1991 were unrelated to the MSEA farming systems because the samples were collected prior to the beginning of the MSEA study. The primary source of the elevated nitrate-N concentrations (figs. 17 and 18 ) is decomposition of alfalfa grown on the research area during 1981-89. Another likely source of the elevated nitrate-N is nitrogen in the starter fertilizer applied to corn grown during 1990 . The primary source of the elevated chloride is potassium-chloride in the starter fertilizer applied to corn grown on the research area during 1990. Another potential source for the chloride is application of potassium chloride to the alfafa grown during 1981-89.

There is a remote possibility that the source of the elevated nitrate- $\mathrm{N}$ in the research area is nitrogen applied to a corn field located immediately west of well MC17 (fig. 17). If the nitrate-N originated from this corn field, upgradient wells $\mathrm{MC} 2, \mathrm{MC} 3$, and $\mathrm{MC} 11$ should have had nitrate- $\mathrm{N}$ concentrations similar to the field wells. However, nitrate- $\mathrm{N}$ concentrations in these upgradient wells were generally less than concentrations in the research area (fig. 17). In addition, nitrate- $\mathrm{N}$ in ground water from beneath this corn field would take about 10 years to travel the $0.3 \mathrm{~km}$ to the closest field well (MC28) and would take about 30 years to travel the $0.9 \mathrm{~km}$ to reach the furthest field well (MC10, fig. 17), based on an estimated ground-water velocity of $28 \mathrm{~m} / \mathrm{yr}$. Ground water recharged from this upgradient field would have been displaced vertically downward by recharge that occurred along the flow path, and would likely be greater than $90 \mathrm{~cm}$ below the water table. However, the samples from the field wells were collected from near the water table. Based on chlorofluorocarbon (CFC) age dating (J.K. Böhlke, U.S. Geological Survey, oral commun., 1993), this ground water near the water table was recharged less than 4 years prior to sampling. Therefore, this ground-water must have recharged relatively near each well rather than in the corn field west of well MC17, which is an unlikely source of the elevated nitrate- $\mathrm{N}$ in the research area.

Although most of the field wells had elevated concentrations of nitrate- $\mathrm{N}$ and chloride relative to concentrations in upgradient and off-site wells, concentrations in the field wells varied widely. This variability in the concentrations of nitrate- $\mathrm{N}$ and chloride likely indicates that transport of these constituents to ground water was highly variable, even within an area of relatively homogeneous land use. This variability is related to a number of factors including spatial variations in soil properties, water infiltration rates, topography, plant uptake, precipitation, and application rates.

\section{Cemparison to Regienal Ground-Woter Quality}

The median concentration of nitrate- $\mathrm{N}$ in the field wells was the same as the median concentration of 10 $\mathrm{mg} / \mathrm{L}$ in 19 ground-water samples collected in the Anoka Sand Plain during 1990. Ground-water samples were collected in agricultural areas from wells completed mostly in the upper $2.5 \mathrm{~m}$ of the saturated zone. The median concentration of chloride in the field wells of 11 $\mathrm{mg} / \mathrm{L}$ was also similar to the median concentration of 14 $\mathrm{mg} / \mathrm{L}$ measured in the Anoka Sand Plain. Based on these results, therefore, ground-water quality in field wells is similar to shallow ground-water quality in agricultural areas of the Anoka Sand Plain.

The median concentration of nitrate- $\mathrm{N}$ in ground water from the upgradient, wetland, and off-site wells were similar to the median concentration of $2.8 \mathrm{mg} / \mathrm{L}$ in the 


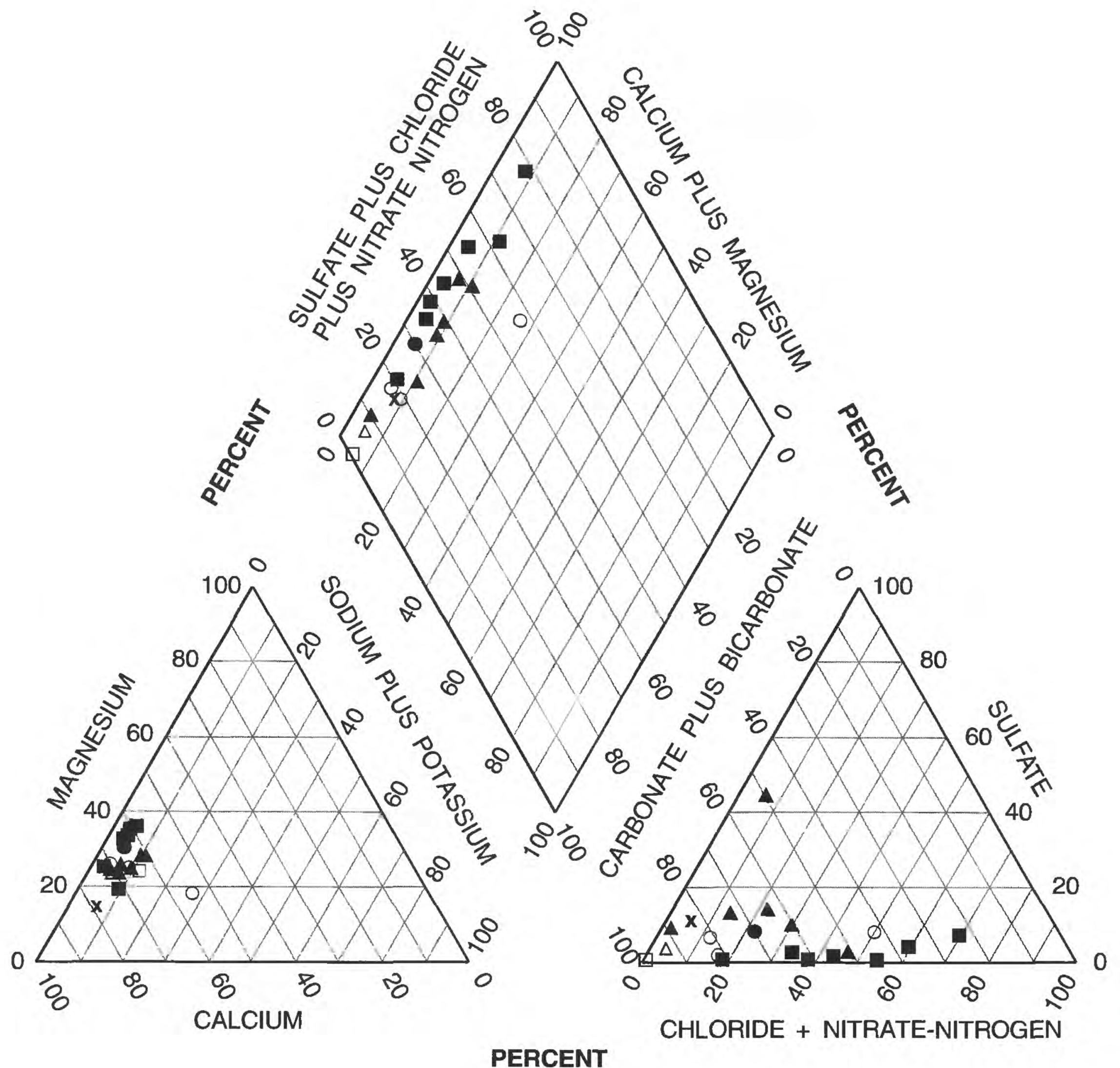

EXPLANATION

- Field well

A Upgradient well

Wetland well

- Off-site well (median) x Battle Brook

$\square$ Mount Simon-Hinckley aquifer well

$\Delta$ Confined-drift aquifer well

Figure 19.--Chemical character of water in the study area, April 1991. 
Anoka Sand Plain reported by Anderson (1993).

Anderson collected 100 ground-water samples from a variety of land-use settings and at depths ranging from 0 to $13 \mathrm{~m}$ below the water table, which are representative of average ground-water quality in the Anoka Sand Plain. The similarity in median nitrate- $\mathrm{N}$ concentrations between the Anderson study and the upgradient, wetland, and off-site areas may be an indication that ground-water quality in these parts of the study area are more representative of average regional ground-water quality within the sand plain than is water quality at the research site.

\section{Other Inorganic Constituents}

Concentrations of sulfate from the three upgradient wells near wooded areas (wells MC2, MC3, and MC15) ranged from 26 to $43 \mathrm{mg} / \mathrm{L}$ with a median of $32 \mathrm{mg} / \mathrm{L}$, compared to a median of $3.0 \mathrm{mg} / \mathrm{L}$ for the field wells (Delin and others, 1994, table 2). The much greater concentration of sulfate in these three wells accounts for the much greater median concentration of sulfate in the upgradient wells compared to other wells in the study area (fig. 18). The concentration of sulfate in well MC2 was nearly as great as the concentration of bicarbonate (Delin and others, 1994, table 2). Therefore, ground water in the wooded area near MC2 was a calcium-bicarbonatesulfate type (fig. 19). The concentrations of sulfate were $4.4 \mathrm{mg} / \mathrm{L}$ and near the detection limit of $0.02 \mathrm{mg} / \mathrm{L}$ in the confined-drift and Mount Simon-Hinckley aquifers, respectively.

Concentrations of dissolved oxygen (DO) in the field wells were between $5.75 \mathrm{mg} / \mathrm{L}$ and $10.50 \mathrm{mg} / \mathrm{L}$ with a median value of $7.97 \mathrm{mg} / \mathrm{L}$ (fig. 20). These values indicate that shallow ground water near the water table was oxygenated, as would be expected. Concentrations of DO in both the confined-drift and Mount SimonHinckley aquifers were $0.2 \mathrm{mg} / \mathrm{L}$. Measurement of DOat these low concentrations, however, may not be accurate because of air leakage into the water being pumped. Therefore, it is possible that water from these deeper aquifers was anoxic.

The median value of specific conductance for the field wells of 376 microsiemens per centimeter at 25 degrees Celsius $(\mu \mathrm{S} / \mathrm{cm})$ was greater than the median values for the upgradient wells $(239 \mu \mathrm{S} / \mathrm{cm})$, wetland wells ( 280 $\mu \mathrm{S} / \mathrm{cm})$, and the off-site wells $(318 \mu \mathrm{S} / \mathrm{cm})($ fig. 20$)$. The greater specific conductance for the field wells reflects a greater concentration of dissolved solids in the ground water compared to the other wells. Greater dissolved solids in the field wells is related to slightly greater concentrations of calcium, magnesium, chloride, and nitrate- $\mathrm{N}$ compared to the other wells.
The median concentrations of calcium $(41 \mathrm{mg} / \mathrm{L})$ and magnesium $(13 \mathrm{mg} / \mathrm{L})$ in ground water from the field wells were greater than the median concentrations in all of the other land-use settings, although the range of concentrations in the different settings was similar (fig. 18). The wetland wells had the greatest median concentration of sodium and the smallest median concentration of silica. Concentrations of most of the major cations and anions and specific conductance were lower in Battle Brook than medians in ground water throughout the study area (figs. 18 and 20). Thus, Battle Brook was generally more dilute than the ground water. However, concentrations of silica, bicarbonate, and sulfate in Battle Brook were similar to concentrations in the wetland wells. Concentrations of potassium were similar in all land-use settings (fig. 18). Concentrations of major cations and bicarbonate in the confined-drift and Mount Simon-Hinckley aquifers were generally greater than the median concentrations in the surficial aquifer (fig. 18). Bicarbonate accounted for nearly 100 percent of the total anion abundance in these deeper aquifers (fig. 19).

Dissolved iron was not present above the detection limit of $0.06 \mathrm{mg} / \mathrm{L}$ in most samples from the surficial aquifer. Dissolved iron, which is predominantly ferric iron at natural pH's (between 6 and 10; fig. 20), was detected at concentrations of 0.66 and $1.95 \mathrm{mg} / \mathrm{L}$ in two of the wetland wells (Delin and others, 1994, table 2). The presence of ferric iron may indicate the presence of reducing conditions in the ground water (Hem, 1992). These reducing conditions were not reflected in the DO values at these wells, however, because of air leakage from the pump into the water during well purging.

\section{Herbicides}

Soil samples collected during April 1991 to a depth of $15 \mathrm{~cm}$ below land surface were analyzed for concentrations of the herbicides atrazine and alachlor. The herbicides were not detected above the detection limit for soils of 5 parts per billion.

\section{Atrazine and Atrazine Metabolites}

The herbicide atrazine was detected by gas chromatography/mass spectroscopy (GC/MS) in two of the seven field wells at concentrations of 0.04 and 0.17 $\mu \mathrm{g} / \mathrm{L}$ (fig. 21 ), well below the USEPA recommended $\mathrm{MCL}$ of $3 \mu \mathrm{g} / \mathrm{L}$. The median concentration in the field wells was less than the qualitative detection limit of 0.01 $\mu \mathrm{g} / \mathrm{L}$ (fig. 20). Atrazine metabolite de-ethylatrazine (DEA) was the most frequently detected herbicide or metabolite (Delin and others, 1994, table 3). There were detections of DEA in five of the seven field wells at 

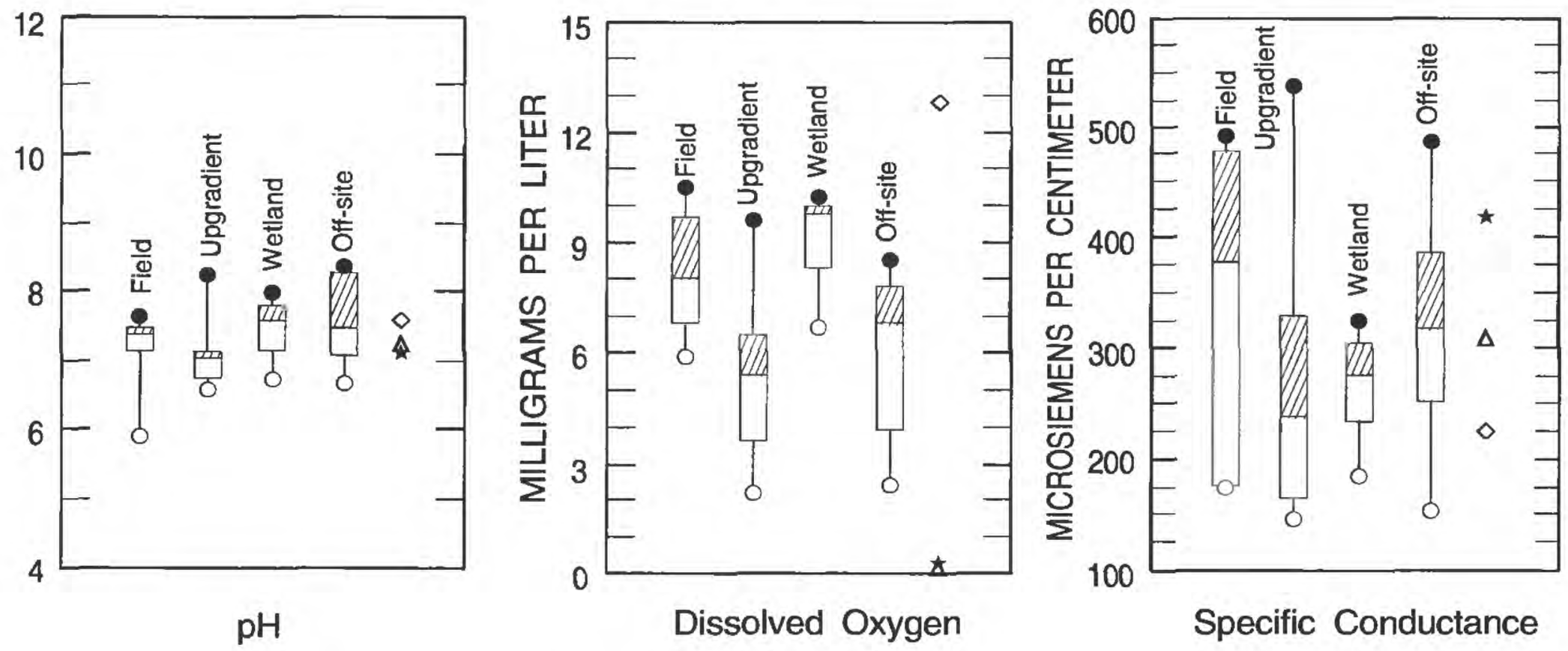

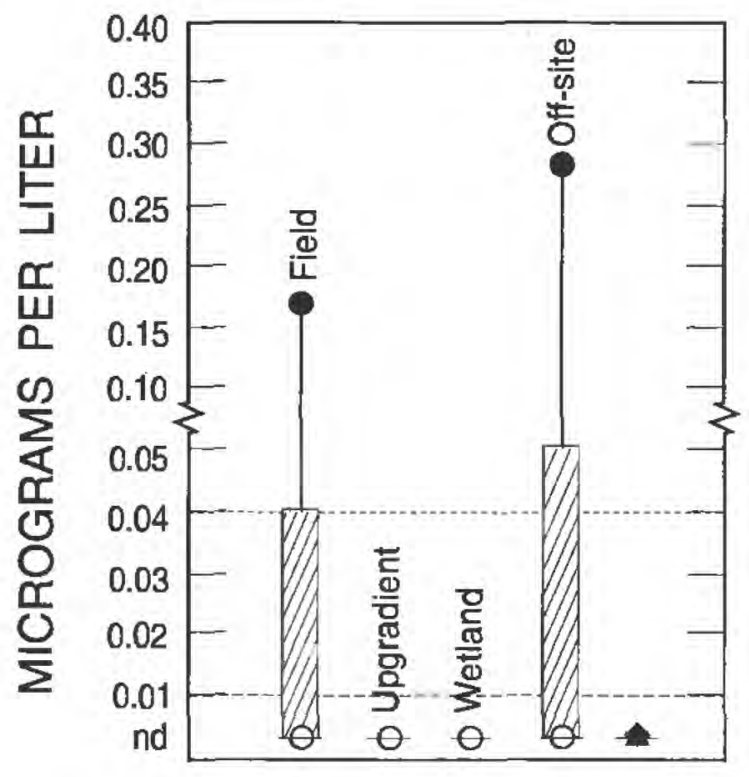

Atrazine

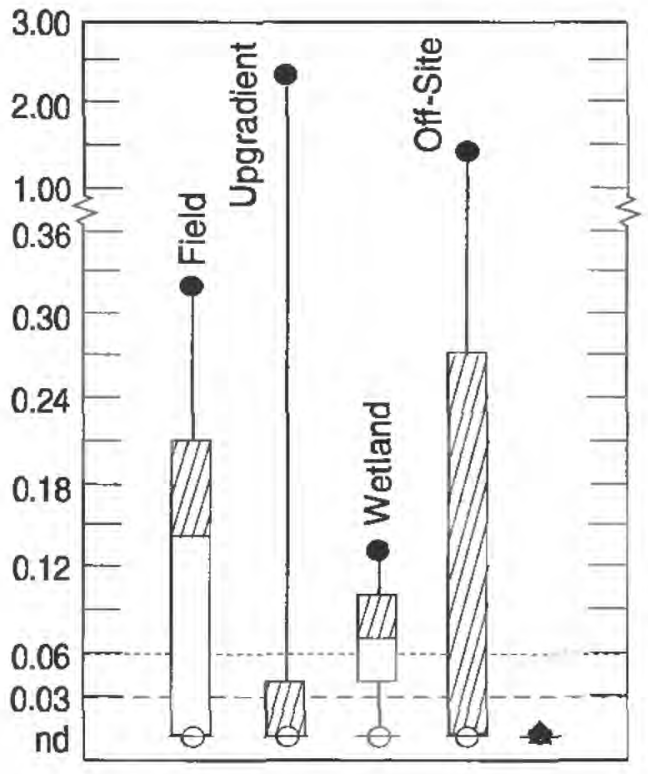

De-ethylatrazine

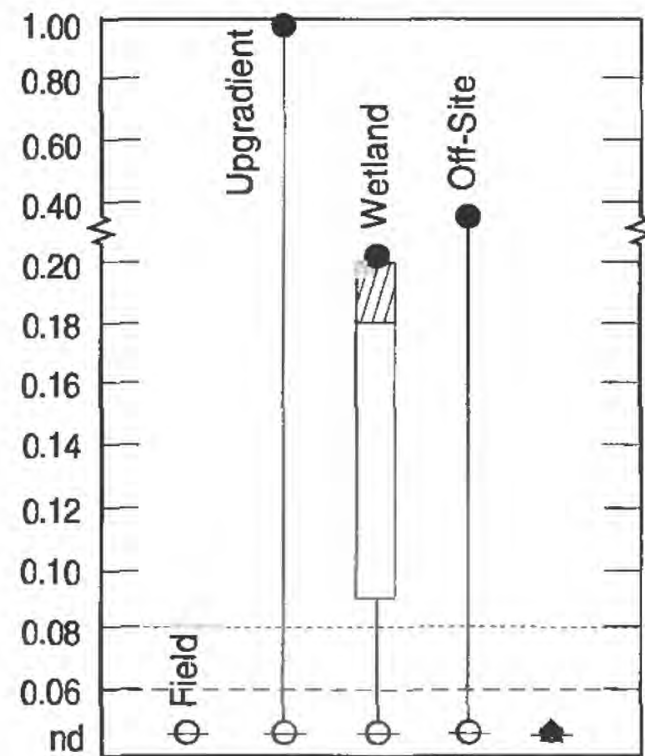

De-isopropylatrazine

\section{EXPLANATION}

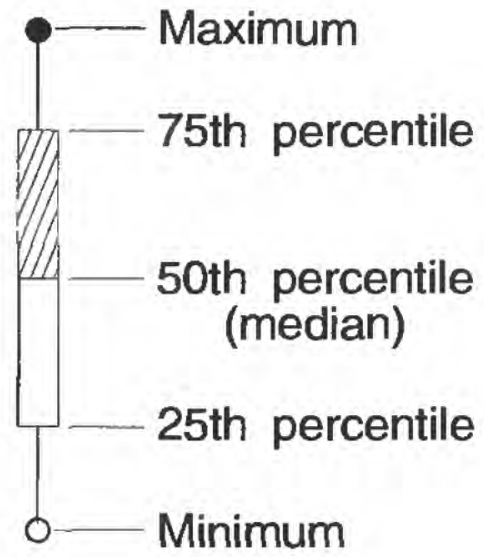

- Battle Brook

* Mount Simon aquifer

$\Delta$ Confined-drift aquifer
Reporting limit

Detection limit

nd No Detection

Number of wells included
in the analysis in each
grouping of wells
7 Field wells
6 Upgradient wells
3 Wetland wells
13 Off-site wells

Figure 20.--Statistical distribution of selected herbicides and field parameters in the study area, April 1991. 


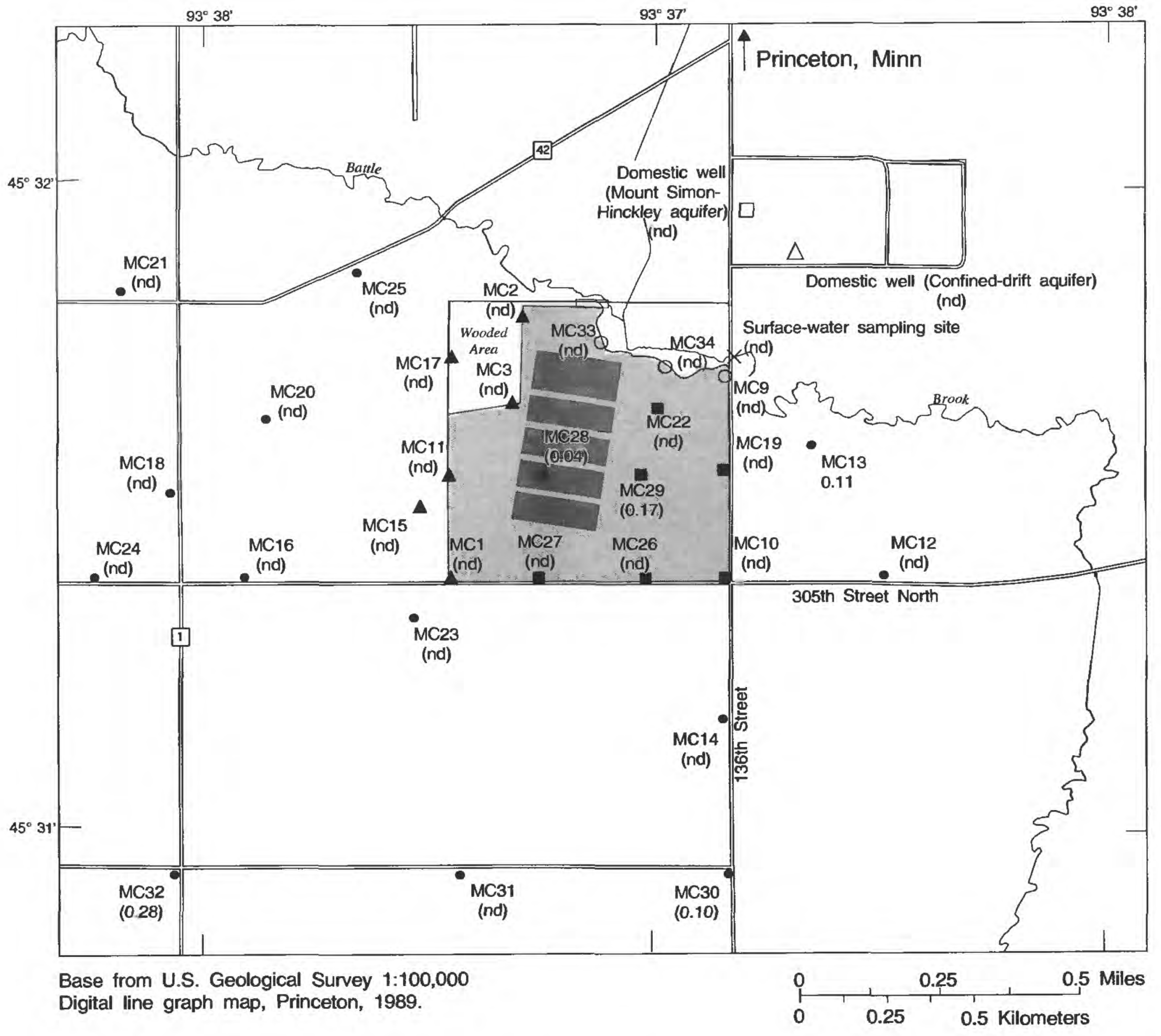

EXPLANATION

Cropped area

Research area, including cropped areas

Observation wells completed in the surficial aquifer at or near the water table-Number in parentheses indicates concentration above reporting limit of 0.04 micrograms per liter
MC29
(0.17) Field well and identifier
$\circ \underset{\text { (nd) }}{\text { MC9 Wetland well and identifier }}$
\ MC17 Upgradient well and identifier
- MC13 Off-site well and identifier
(nd)

nd No detection above detection limit of 0.01 micrograms per liter

Figure 21.--Concentrations of atrazine in the study area, April 1991. 
concentrations ranging from 0.12 to $0.32 \mu \mathrm{g} / \mathrm{L}$ with a median concentration of $0.14 \mu \mathrm{g} / \mathrm{L}$ (fig. 22). Atrazine metabolite de-isopropylatrazine (DIA) was not detected above the qualitative detection limit of $0.06 \mu \mathrm{g} / \mathrm{L}$ in the field wells (fig. 23).

Atrazine was not detected above the qualitative detection limit of $0.01 \mu \mathrm{g} / \mathrm{L}$ in the six upgradient wells. However, DEA was detected in upgradient well MC2 at a trace concentration (less than the quantitative reporting limit of $0.06 \mu \mathrm{g} / \mathrm{L}$ ) and in upgradient well MC11 at a concentration of $2.3 \mu \mathrm{g} / \mathrm{L}$ (fig. 22). The median concentration of DEA in upgradient wells was below the qualitative detection limit of $0.03 \mu \mathrm{g} / \mathrm{L}$ (fig. 20). In upgradient well MC11, DIA was detected at a concentration of $0.98 \mu \mathrm{g} / \mathrm{L}$ (fig. 23). The median concentration of DIA in upgradient wells was less than the quantitative reporting limit of $0.06 \mu \mathrm{g} / \mathrm{L}$ (fig. 20). Atrazine and DEA were detected more frequently and at higher median concentrations in the field wells than in the upgradient wells (fig. 20).

The greatest concentrations of DEA $(2.3 \mu \mathrm{g} / \mathrm{L})$ and DIA $(0.98 \mu \mathrm{g} / \mathrm{L})$ within the study area were in upgradient well MC11 (figs. 22 and 23) (Delin and others, 1994, table 3). Detection of these compounds at such high concentrations is likely due to application of atrazine on a garden-sized corn plot located $10 \mathrm{~m}$ upgradient (west) of the well or a point-source spillage in the close vicinity of well MC11.

Atrazine was not detected above the qualitative detection limit of $0.01 \mu \mathrm{g} / \mathrm{L}$ in the three wetland wells. However, DEA was detected in two of the wetland wells at concentrations of 0.07 and $0.13 \mu \mathrm{g} / \mathrm{L}$ (fig. 22). In addition, DIA was also detected in two of the wetland wells at concentrations of 0.18 and $0.21 \mu \mathrm{g} / \mathrm{L}$ (fig. 23).

Atrazine was detected in 3 of the 13 off-site wells at concentrations ranging from 0.10 to $0.28 \mu \mathrm{g} / \mathrm{L}$ (fig. 21) (Delin and others, 1994, table 3). Concentrations of DEA in five of the off-site wells ranged from 0.14 to $1.4 \mu \mathrm{g} / \mathrm{L}$ (fig. 22). Concentrations of DIA in off-site wells MC30 and $\mathrm{MC} 13$ were 0.30 and $0.34 \mu \mathrm{g} / \mathrm{L}$, respectively (fig. 23).

Atrazine was detected in only two of the four field wells in which concentrations of nitrate- $\mathrm{N}$ were $10 \mathrm{mg} / \mathrm{L}$ or greater (Delin and others, 1994, table 3). Similarly, atrazine was detected in only two of the six field wells in which concentrations of chloride were $10 \mathrm{mg} / \mathrm{L}$ or greater. This lack of correlation between atrazine and nitrate-N or chloride in ground water in the research area may indicate a different source for atrazine compared to nitrate- $\mathrm{N}$ and chloride. Concentrations of atrazine were not significantly correlated with any of the other inorganic or organic constituents. Similarly, there was no correlation between concentrations of DEA and nitrate-N.
Concentrations of DEA were significantly correlated with concentrations of chloride, however $(r=0.79, p=0.035)$. Concentrations of DEA were not significantly correlated with any other inorganic or organic constituents.

\section{Ratio of Atrazine to Atrazine Metabolites}

Other studies (Thurman and others, 1992; Thurman and others, in press) have demonstrated that the DEA to atrazine ratio (DAR) can be a useful tool for evaluating the history and pathways of atrazine. In the two field wells in which both DEA and atrazine were present, the DAR values were 1.2 and 3.5. These DAR values are typical of those measured in ground water from agricultural areas elsewhere in the midwest where atrazine is used (Thurman and others, 1992; Kolpin and others, 1993). Because degradation of atrazine to DEA mostly takes place in the unsaturated zone, DAR values measured in ground water are generally greater than 1.0 (Thurman and others, 1992; Thurman and others, in press). Values of DAR less than 1.0 indicate rapid transport of atrazine to ground water (Thurman and others, in press). Therefore, the DAR values measured in ground water from the field wells were consistent with leaching of atrazine and atrazine metabolites from surface applications, but did not indicate rapid transport of atrazine to ground water that might occur from transport through macropores in the unsaturated zone or from point-source spills.

The ratios of DIA to DEA ( $\left.D^{2} R\right)$ in wetland wells MC33 and MC34 were 1.4 and 3.0, respectively. These $D^{2} R$ values are greater than typical values $(0.0$ to 0.6$)$ for ground water affected by atrazine applications on land surface (Meyer and Thurman, in press). These $D^{2} R$ values are consistent, however, with values measured in surface water or in ground water affected by use of other triazine herbicides such as cyanazine (Meyer and Thurman, in press).

The DAR values in off-site wells MC13, MC30, and $M C 32$ ranged from 1.3 to 12.7 . The $D^{2} R$ values for offsite wells $\mathrm{MC} 13$ and $\mathrm{MC} 30$ was 0.2 and 1.7 , respectively. The $D^{2} R$ value of 1.7 for well MC 30 was anomalously high for ground water unless the ground water had been affected by application of other triazine herbicides such as cyanazine.

\section{Source of Atrazine and Atrazine Metabolites in}

\section{the Research Area}

The most likely source of the atrazine, DEA, and DIA detected in the field wells is application of atrazine on the research area prior to 1991. A high percentage of the field 


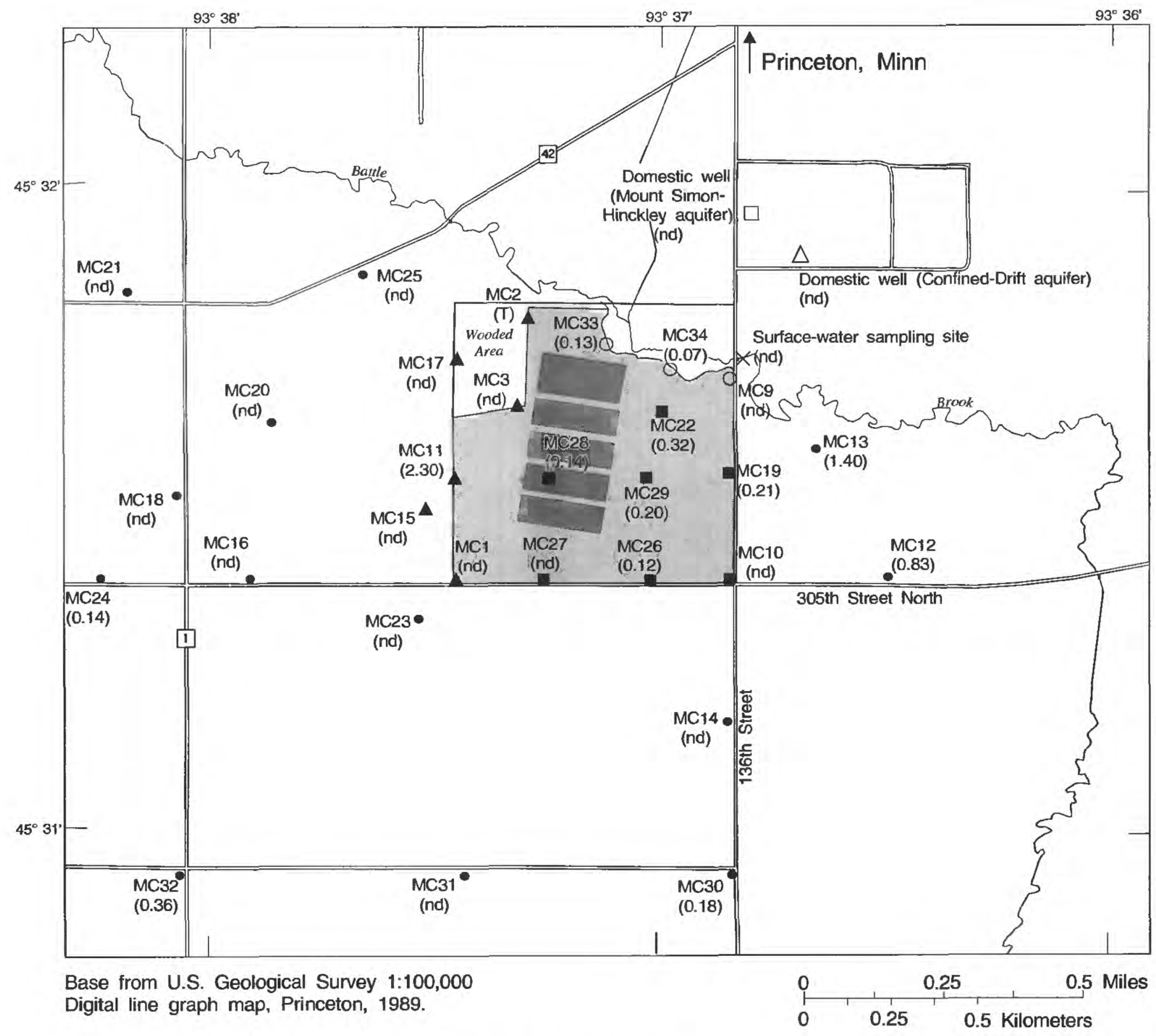

\section{EXPLANATION}

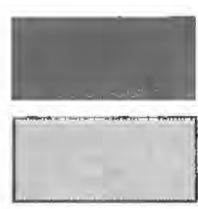

Cropped area

Research area, including cropped areas

Observation wells completed in the surficial aquifer at or near the water table-Number in parentheses indicates concentration above reporting limit of 0.06 micrograms per liter
- ${ }_{(0.14)}^{\text {MC28 }}$ Field well and identifier
${ }_{(0.18)}^{M C 33}$
Wetland well and identifier

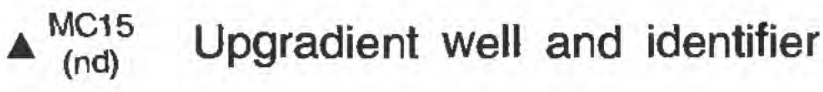
- ${ }_{(0.36)}^{\text {MC32 }}$
Off-site well and identifier
nd No detection above detection limit of 0.03 micrograms per liter
$\mathrm{T} \quad$ Trace concentration between detection limit and reporting limit

Figure 22.-Concentrations of de-ethylatrazine in the study area, April 1991. 


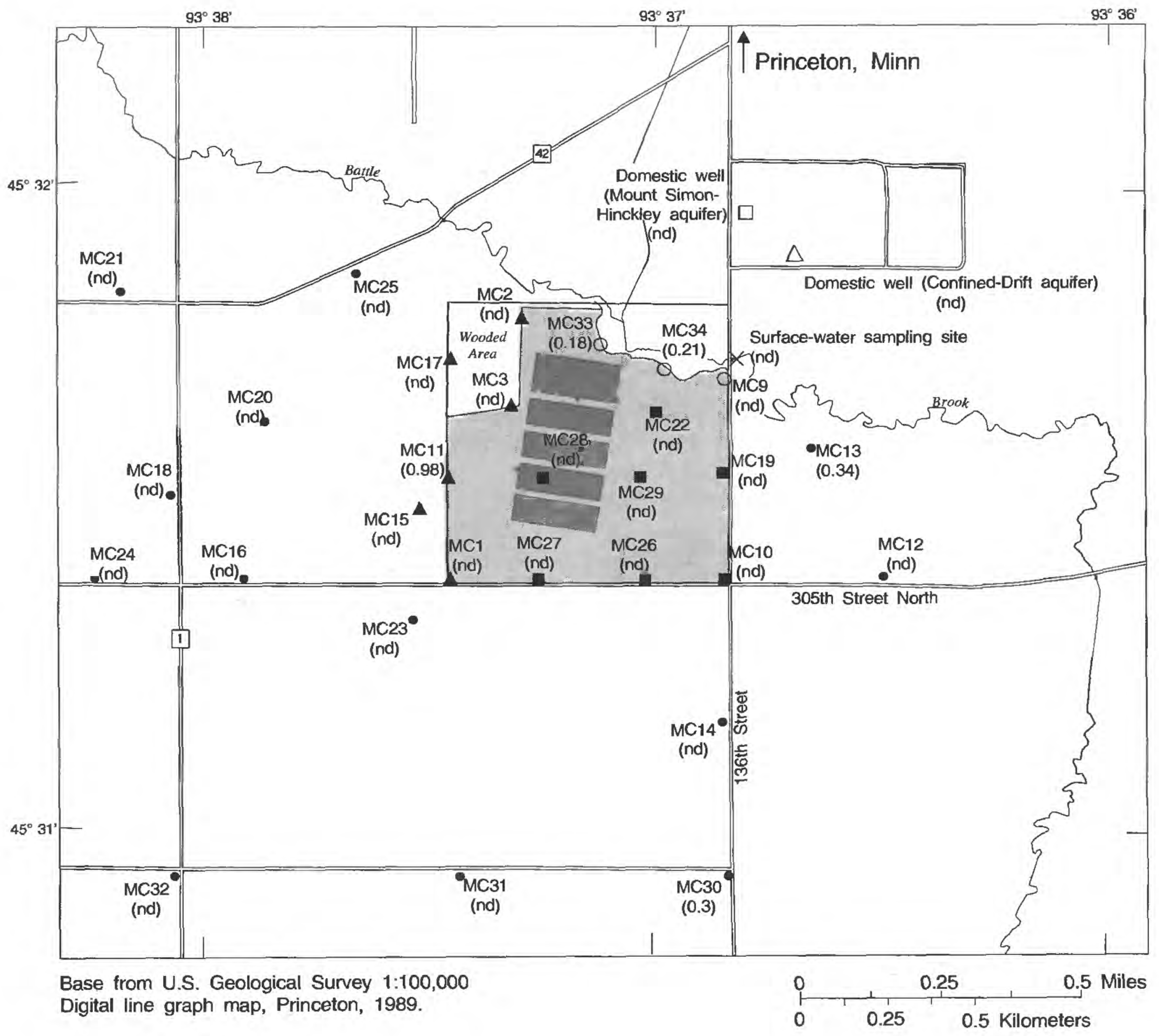

\section{EXPLANATION}

Cropped area

Research area, including cropped areas

Observation wells completed in the surficial aquifer at or near the water table-Number in parentheses indicates concentration above reporting limit of 0.08 micrograms per liter

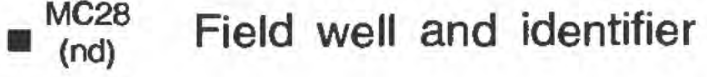
MC33
$\underset{\text { (nd) }}{M C_{15}}$ Upgradient well and identifier
$O(0.21)$
Wetland well and identifier

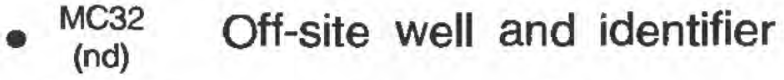
nd No detection above detection limit of 0.06 micrograms per liter

Figure 23.--Concentrations of de-isopropylatrazine in the study area, April 1991. 
wells (71 percent) had detections of DEA compared to the off-site wells ( 38 percent), providing support for this assertion. If atrazine was applied to the research area during 1990, some atrazine likely remained in the saturated zone in 1991 because the half life of atrazine in soils is typically less than 50 days (Winkelman and Klaine, 1990; Bacci and others, 1989) and in natural waters is about 170 days (Bacci and others, 1989; Jones and others, 1982). Support for this assertion lies in the fact that the sampled ground water was recharged less than four years prior to collection, based on CFC age dating (J.K. Bobhlke, U.S. Geological Survey, oral commun., 1993). However, the person who farmed the research area during 1990 told relatives that he did not apply atrazine to corn on the research area, effectively eliminating application during 1990 as a source. This statement cannot be confirmed, however, due to inadequate records and because the farmer has since passed away. During the years 1981-89, herbicides were not applied because alfalfa was grown on the research area. If the source of the atrazine, DEA, and DIA was application to the research area prior to 1981 , some of the compounds must have been released from the unsaturated zone during the last four years, based on CFC age dating. However, the half-life of atrazine in the research area would likely be much greater than the typical values stated above if the source was application prior to 1981 .

Another source for the atrazine, DEA, and DIA detections in the field wells is deposition of atrazine from precipitation. Although atrazine was not detected in rain samples collected during the summer of 1992, it was detected in rain samples collected during 1993 at a median concentration of $0.04 \mu \mathrm{g} / \mathrm{L}$ with a maximum concentration of $2.90 \mu \mathrm{g} / \mathrm{L}$ (P.D. Capel, U.S. Geological Survey, written commun., 1994). However, if precipitation was the primary source of atrazine, DEA, and DIA in the research area, these compounds should have been present in similar concentrations throughout the study area. As stated earlier, however, there was a greater frequency of detection for these compounds within the research area compared to elsewhere in the study area. Therefore, precipitation likely is not the primary source of atrazine, DEA, and DIA in the research area.

A final potential source of atrazine, DEA, and DIA in the field wells is application of atrazine to the corn field located immediately west of well MC17 (fig. 21), with subsequent transport of the chemical with the ground water to the research area. Atrazine in ground water from beneath this upgradient corn field would take about 10 years to travel the $0.3 \mathrm{~km}$ to the closest field well (MC28) and would take about 30 years to travel the $0.9 \mathrm{~km}$ to reach the furthest field well (MC10, fig. 21), based on an estimated ground-water velocity of $28 \mathrm{~m} / \mathrm{yr}$. However, ground water recharged from this upgradient field would have been displaced vertically downward by recharge that occurred along the flow path, and would likely be greater than $90 \mathrm{~cm}$ below the water table beneath the research area. This assumption is supported by results of the CFC age dating discussed in the last paragraph. In addition, atrazine and DEA were not detected in well MC17 located immediately downgradient of the corn field. Therefore, atrazine in ground water from this upgradient field is an unlikely source of the detections in the research area.

The most likely source of the trace-level concentration of DEA in upgradient well MC2 is precipitation. Other potential sources are (1) application upgradient of the research area, (2) analytical error, or (3) contamination of the sample during field collection. The possibility that DEA originated from application of atrazine on an upgradient field is more feasible for well MC2 than for the field wells because the distance from the upgradient field to well MC2 (about $0.25 \mathrm{~km}$ ) was shorter than for the field wells. However, because atrazine or its metabolites were not detected in well MC3 (located about the same distance from the upgradient field) an upgradient source is unlikely.

\section{Comparison to Regional Ground-Water Quality}

Atrazine was detected in the ground water within the study area in similar frequencies and concentrations to ground water sampled across the Anoka Sand Plain during 1990. Ground-water samples were collected during 1990 in agricultural areas from wells completed mostly in the upper $2.5 \mathrm{~m}$ of the saturated zone. Atrazine was detected in 11 of the 34 wells sampled in the Anoka Sand Plain (32 percent), with a median concentration of less than $0.10 \mu \mathrm{g} / \mathrm{L}$. By comparison, the median concentration of atrazine in the study area was less than the detection limit of $0.01 \mu \mathrm{g} / \mathrm{L}$ (fig. 20). Atrazine was detected in 2 of the 7 field wells ( 29 percent), a very similar detection frequency to the regional study. The detection frequency for the entire study area ( 5 of 29 wells, 17 percent) was slightly less than the regional frequency, most likely because of the mixed land use within the study area.

The most frequently detected herbicide or herbicide metabolite in the study area and across the Anoka Sand Plain was DEA. This atrazine metabolite also was generally present in the greatest concentration of any herbicide or herbicide metabolite in the Anoka Sand Plain. DEA was detected in 13 of the 17 samples collected in the study area and across the Anoka Sand Plain (76 percent) analyzed by GC/MS with a median 
concentration of $0.15 \mu \mathrm{g} / \mathrm{L}$. DEA was detected in 5 of the 7 field wells ( 71 percent) with a median concentration of $0.14 \mu \mathrm{g} / \mathrm{L}$. The detection frequency for the entire study area (14 of 29 wells, 48 percent) was less than the frequency in the Anoka Sand Plain, most likely because of the mixed land use in the study area.

There were more frequent detections of DIA in the study area than in the Anoka Sand Plain, and generally at greater concentrations. DIA was detected in 5 of 29 wells in the study area (17 percent) at concentrations ranging from the detection limit of $0.06 \mu \mathrm{g} / \mathrm{L}$ to $0.98 \mu \mathrm{g} / \mathrm{L}$. DIA was detected in only 1 of 17 wells analyzed by GC/MS in the Anoka Sand Plain ( 6 percent) at a concentration of $0.06 \mu \mathrm{g} / \mathrm{L}$.

In general, both the frequency of detections and concentrations of herbicides and herbicide metabolites in the study area (Delin and others, 1994, table 3) and across the Anoka Sand Plain were strikingly similar. This result indicates that herbicide concentrations in the study area are representative of ground-water quality in agricultural areas of the Anoka Sand Plain.

\section{Other Herbicides}

Alachlor, metribuzin, and alachlor metabolite chloroalachlor were not detected in the field, upgradient, wetland, off-site wells, or in the Anoka Sand Plain above the qualitative detection limits of $0.01,0.03$, and 0.06 $\mu \mathrm{g} / \mathrm{L}$, respectively (Delin and others, 1994, table 3). Alachlor metabolite 2,6-diethylanaline was only detected at a trace concentration $(0.03 \mu \mathrm{g} / \mathrm{L})$ in one well within the study area (field well MC26). Metolachlor was also only detected in one well in the study area (off-site well MC32) and in one well in the Anoka Sand Plain. Herbicides were not detected in Battle Brook, the confined-drift aquifer, or the Mount Simon-Hinckley aquifer.

\section{SUMMARY}

The Management Systems Evaluation Area (MSEA) program was part of a multi-scale, inter-agency initiative to evaluate the effects of agricultural systems on water quality at several locations throughout the midwest corn belt. The Minnesota MSEA project was one of five MSEAs selected to represent the principal hydrogeologic settings and geographic diversity of prevailing management systems. The interagency research objective of the Minnesota MSEA was to evaluate the effects of modified and prevailing farming systems on ground-water quality in a sand-plain setting near Princeton, Minnesota and at satellite locations in North Dakota, South Dakota, and Wisconsin.
The 65-ha research area is located about $5 \mathrm{~km}$ southwest of Princeton, Minnesota. The research area is in the Anoka Sand Plain, an area of glacial outwash covering about $4,400 \mathrm{~km}^{2}$. The water-quality monitoring network within the research area consisted of 29 observation wells and 22 multiport wells (MPORTs). In addition, 13 observation wells were located outside the research area.

The surficial aquifer consists primarily of fine to medium sand in the unsaturated zone and medium to coarse sand and gravel below the water table. The depth to the base of the surficial aquifer is greatest beneath the northernmost cropped area and least in the southeastern corner of the research area. The average depth to the water table is about $3.6 \mathrm{~m}$ below land surface and the saturated thickness of the aquifer ranges from about 4 to greater than $15 \mathrm{~m}$. Ground-water recharge to the surficial aquifer during $1992(11.7-25.7 \mathrm{~cm})$ was lower than recharge during $1991(4.9-13.2 \mathrm{~cm})$ because of reduced precipitation ( 58.5 centimeters during 1992 and 94.5 centimeters during 1991).

Estimates of saturated horizontal hydraulic conductivity of the surficial aquifer were made based on five methods. Results were within aboul two orders of magnitude and agree favorably with estimates from a previous study in the Anoka Sand Plain. The smallest hydraulic conductivities were obtained using laboratory analyses $(0.0052 \mathrm{~cm} / \mathrm{s})$ and the greatest hydraulic conductivity was obtained from results of an aquifer test $(0.2820 \mathrm{~cm} / \mathrm{s})$. Of the five methods used, the estimate of hydraulic conductivity based on chloride time of travel $(0.0655 \mathrm{~cm} / \mathrm{s})$ is considered most accurate and representative of the surficial aquifer in the research area.

Ground-water flow is generally from west to east across the research area. From about November through March of each year, ground-water flow is from an area of higher hydraulic head west of the research area toward Battle Brook, which forms a natural discharge boundary. A divide in the water table nearly bisects the research area, separating flow to the south and flow to the north. Variable ground-water recharge during April through May of 1991 resulted in variable ground-water-flow directions. From about June through October, groundwater-flow directions stabilized into a configuration that was similar to the flow directions observed during the winter months.

Effects of previous land use on the research area and on upgradient areas were evident based on results of groundwater-quality analyses of samples collected during April 1991. Concentrations of nitrate- $\mathrm{N}$ in the surficial aquifer equaled or exceeded the USEPA MCL of $10 \mathrm{mg} / \mathrm{L}$ in four of the seven wells in the research area. The median 
concentration of nitrate- $\mathrm{N}$ from these wells was $10 \mathrm{mg} / \mathrm{L}$ compared to a median concentration of $2.1 \mathrm{mg} / \mathrm{L}$ in upgradient areas and a median concentration of $3.4 \mathrm{mg} / \mathrm{L}$ in wells adjacent to a wetland. Similarly, the median concentration of chloride from wells in the research area (11 $\mathrm{mg} / \mathrm{L}$ ) exceeded the median in the upgradient wells $(3.8 \mathrm{mg} / \mathrm{L})$ and in the wetland wells $(9.2 \mathrm{mg} / \mathrm{L})$.

The elevated concentrations of nitrate- $\mathrm{N}$ and chloride in ground water beneath the research area, compared to other areas, likely indicates use of these chemicals on the research area prior to implementation of the MSEA farming systems. This is supported by results of chlorofluorocarbon age dating which indicates that water in the upper $90 \mathrm{~cm}$ of the saturated zone was recharged less than four years prior to sampling. Thus, groundwater recharge probably occurred relatively near each well site. Likely on-site sources of the elevated nitrate-N beneath the research area include decomposition of alfalfa, grown on-site during 1981-89, and application of nitrogen fertilizer to corn grown during 1990. A likely on-site source of the elevated chloride is application of potassium-chloride fertilizer to crops grown on site prior to 1991.

Atrazine was detected by gas chromatography/mass spectroscopy in two of the seven wells in the research area at concentrations of 0.04 and $0.17 \mu \mathrm{g} / \mathrm{L}$, well below the USEPA recommended MCL of $3 \mu \mathrm{g} / \mathrm{L}$, with a median concentration less than the qualitative detection limit of $0.01 \mu \mathrm{g} / \mathrm{L}$. De-ethylatrazine (DEA) was the most frequently detected herbicide or herbicide metabolite. DEA was detected in 5 of the 7 field wells at concentrations ranging from 0.12 to $0.32 \mu \mathrm{g} / \mathrm{L}$ with a median concentration of $0.14 \mu \mathrm{g} / \mathrm{L}$. Atrazine metabolite de-isopropylatrazine was not detected above the qualitative detection limit of $0.06 \mu \mathrm{g} / \mathrm{L}$ in the research area.

Determining the sources of atrazine and DEA detected in the research area is difficult because atrazine was not applied to the area during 1981-90. Possible sources of atrazine and atrazine metabolites in the ground water include: (1) deposition of atrazine from precipitation (2) application of atrazine on the research area prior to 1980 , (3) application of atrazine to a field located upgradient in the flow system, with subsequent transport of the chemical with the ground water to the research area. Because atrazine and DEA were detected in rain samples collected during 1993, the most likely sources of atrazine are precipitation or application of atrazine to corn grown on the research area prior to 1980.

\section{REFERENCES}

Anderson, H.W., Jr., 1993, Effects of agricultural and residential land use on ground-water quality, Anoka Sand Plain aquifer, east-central Minnesota: U.S. Geological Survey Water-Resources Investigations Report 93-4074, 62 p.

Anderson, J. L., Dowdy, R. H., and Delin, G. N., 1991, Ground water impacts from irrigated ridge-tillage: in Ritter, W.F., ed., Proceedings of the American Society of Civil Engineers, 1991 National Conference on Irrigation and Drainage Engineering, Honolulu, Hawaii, July 23-26, 1991, p. 604-610.

Biacci, E., Renzoni, A., Gaggi, C., Calamari, D., and Franchi, A., 1989, Models, field studies, laboratory experiments-an integrated approach to evaluate the environmental fate of atrazine (s-trazine herbicide): Agriculture, Ecosystems and Environment, vol. 27, no. $1-4$, p. 513-522.

Baker, D.B., Bushway, R.J., Adams, S.A., and Macomber, Carol, 1993, Immunoassay screens for alachlor in rural wells-false positives and an alachlor soil metabolite: Environmental Science and Technology, vol. 27, no. 3, p. 562-564.

Baker, D.G., Haines, D.A., and Strub, J.H., Jr., 1967, Climate of Minnesota Part V, Precipitation Facts Normals and Extremes: University of Minnesota Agricultural Experiment Station Technical Bulletin $254,43 \mathrm{p}$.

Baker, D.G., Nelson, W.W., and Kuehnast, E.L., 1979, Climate of Minnesota Part XII, The hydrologic cycle and soil and water: University of Minnesota Agricultural Experiment Station Technical Bulletin, $23 \mathrm{p}$.

Baker, D.G., Kuehnast, E.L., and Zandlo, J.A., 1985, Climate of Minnesota Part XV, Normal temperatures (1951-80) and their application: University of Minnesota Agricultural Experiment Station Report AD-SB-2777, 66 p.

Bouabid, R., 1992, Soil solution chemistry, mineral weathering, and pedogenesis in sandy outwash soils of east-central Minnesota: Ph.D. Dissertation, Department of Soil Science, University of Minnesota, St. Paul, Minnesota, 167 p.

Boulton, N.S., 1963, Analysis of data from nonequilibrium pumping tests allowing for delayed yield from storage: Institute Civil Engineers Proceedings [London], vol. 26, p. 469-482.

Bouwer, Herman, 1989, The Bouwer and Rice slug test an update: Ground Water, vol. 27 no. 3, p. 304-309.

Bouwer, Herman, and Rice, R.C., 1976, A slug test for determining hydraulic conductivity of unconfined aquifers with completely or partially penetrating 
wells: Water Resources Research, vol. 12, no. 3, p. 423-428.

Cooper, W.S., 1935, History of the Upper Mississippi River in Late Wisconsin and post-glacial time: Minnesota Geological Survey Bulletin 26, 116 p.

Delin, G.N., Landon, M.K., Anderson, J.L., and Dowdy, R.H., 1992, Hydrologic research at the Princeton, Minnesota Management Systems Evaluation Area: U.S. Geological Survey Open-File Report 92-107, 2 p.

Delin, G.N., Landon, M.K., Lamb, J.A., and Anderson, J.L., 1994, Hydrogeologic and water-quality data used to characterize the Management Systems Evaluation Area (MSEA) near Princeton, Minnesota: U.S. Geological Survey Open-File Report $94-337,45 \mathrm{p}$.

Delin, G.N., Landon, M.K., Healy, R.W., and Olsen, H.W., in press, Spatial variability of unsaturate-zone properties in relation to topography in a sand-plain setting near Princeton, Minnesota, in Morganwalp, D.W., and Aronson, D.A., eds., U.S. Geological Survey Toxic Substances Hydrology ProgramProceedings of the technical meeting, Colorado Springs, Colorado, September 20-24, 1993: U.S. Geological Survey Water Resources Investigations Report 94-4014.

Delin, G.N., and Landon, M.K., in press, Effects of topography on the transport of agricultural chemicals near Princeton, Minnesota, 1992, in Morganwalp, D.W., and Aronson, D.A., eds., U.S. Geological Survey Toxic Substances Hydrology Program-Proceedings of the technical meeting, Colorado Springs, Colorado, September 20-24, 1993: U.S. Geological Survey Water Resources Investigations Report 94-4014.

Farnham, R.S., 1956, Geology of the Anoka Sand Plain, in Wright, H.E., assoc. ed., Glacial geology, eastern Minnesota, Field Trip no. 3: Geological Society of America, p. 53-64.

Freeze, R.A., and Cherry, J.A., 1979, Groundwater: Englewood Cliffs, N.J., Prentice-Hall, Inc., 604 p.

Gee, G.W., and Bauder, J.W., 1986, Particle-size analysis, in Klute, A., ed., Methods of Soil Analysis, physical and mineralogical methods: American Society of Agronomy Monograph Number 9. Part 1, Madison, Wisconsin, p. 383-411.

Gianessi, L.P., and Puffer, C.M., 1988, Use of selected pesticides for agricultural crop production in the United States 1982-85: Washington, D.C., Resources for the Future, Inc., Quality of the
Environment Division, $490 \mathrm{p}$.

Grimes, M. F., 1968, Soil survey of Sherburne County, Minnesota: U.S. Department of Agriculture, Soil Conservation Service, 81 p.

Hach Company, 1992, Hach water analysis handbook (2nd ed.): Loveland, Colorado, 831 p.

Hamilton, P.A., Denver, J.M., Phillips, P.J., and Shedlock, R.J., 1993, Water-quality assessment of the Delmarva Peninsula, Delaware, Maryland, and Virginia-Effects of agricultural activities on, and distribution of, nitrate and other inorganic constituents in the surficial aquifer: U.S. Geological Survey Open-File Report 93-40, 87 p.

Helsel, D.R., and Hirsch, R.M., 1992, Statistical methods in water resources: Amsterdam, Netherlands, Elsevier Science Publishers B.V., 522 p.

Hem, J.D., 1992, Study and interpretation of the chemical characteristics of natural water: U.S. Geological Survey Water-Supply Paper 2254, 263 p.

Jacob, C.E., 1963, Determining the permeability of water-table aquifers, in Bentall, Ray, comp., Methods of determining permeability, transmissibility, and drawdown: U.S. Geological Survey Water-Supply Paper 1536-I, p. 245-271.

Kolpin, D.W., Burkhart, M.R., and Thurman, E.M., 1993, Herbicides and nitrate in near-surface aquifers in the Midcontinental United States, 1991: U.S. Geological Survey Water-Supply Paper 2413.

Landon, M.K., Delin, G.N., Lamb, J.A., Dowdy, R.H., and Anderson, J.L., in press, Effects of farming systems on ground-water quality at the Princeton, Minnesota Management Systems Evaluation Area, 1991, in Morganwalp, D.W., and Aronson, D.A., eds., U.S. Geological Survey Toxic Substances Hydrology Program-Proceedings of the technical meeting, Colorado Springs, Colorado, September 20-24, 1993: U.S. Geological Survey Water Resources Investigations Report 94-4014.

Lindholm, G. F., 1980, Ground-water appraisal of sand plains in Benton, Sherburne, Stearns, and Wright Counties, central Minnesota: U.S. Geological Survey Water-Resources Investigations Open-File Report 80-1285, 103 p.

Meyer, M.T. and Thurman, E.M., in press, The degradation and transport of cyanazine metabolites in surface water of the midwestern United States, in Morganwalp, D.W. and Aronson, D.A., eds., U.S. Geological Survey Toxic Substances Hydrology Program-Proceedings of the Technical Meeting, Colorado Springs, Colorado, September 20-24, 
1993: U.S. Geological Survey Water-Resources Investigations Report 94-4014.

Olsen, H.W., Morin, R.H., and Nichols, R.W., 1988, Flow pump application in triaxial testing, in R.T. Donaghe, R.C. Chaney, and M.L. Silver, eds., Advanced Triaxial Testing of Soil and rock, ASTM STP 977: American Society for Testing and Materials, Philadelphia, p. 68-81.

Olsen, H.W., Gill, J.D., Willden, A.T., and Nelson, K.R., 1991, Innovations in hydraulic-conductivity measurements: Geotechnical Engineering 1991, Transportation Research Record 1309, Transportation Research Board, National Research Council, p. 9-17.

Rasmussen, W.C., and Andreason, G.G., 1959, Hydrologic budget of the Beaver Dam Creek Basin Maryland: U.S. Geological Survey Water-Supply Paper 1472, $106 \mathrm{p}$.

Rehm, George, Munter, Robert, Rosen, Carl, and Schmitt, Michael, 1992, Lime needs in Minnesota: University of Minnesota Extension Service Bulletin AG-FO-5956-B, 4 p.

Rehm, George, Schmitt, Michael, and Munter, Robert, 1993, Fertilizer recommendations for agronomic crops in Minnesota: University of Minnesota Extension Service Bulletin BU-6240-E, 23 p.

Rosen, C.J., and Munter, R.C., 1992, Nutrient management for commercial fruit and vegetable crops in Minnesota: University of Minnesota Extension Service Bulletin AG-BU-5886-F, 29 p.

SAS Institute Inc., 1989, SAS/STAT User's Guide, Version 6, Vol. 1 and 2 (4th ed.): Cary, North Carolina, SAS Institute Inc., 1789 p.

Soil and Water Conservation Society, 1993, Agricultural research to protect water quality: Proceedings of the Soil and Water Conservation Society Conference, February 21-24, 1993, Minneapolis, Minnesota, vol. 1, p. 1-15.

Stallman, R.W., 1971, Aquifer-test design, observation, and data analysis: U.S. Geological Survey Techniques of Water-Resources Investigations, book 3, chap. B1, 26 p.

Thurman, E.M., Meyer, Michael, Pomes, Michael, Perry, C.A., and Schwab, A.P., 1990, Enzymelinked immunosorbent assay compared with gas chromatography/mass/spectrometry for the determination of triazine herbicides in water: Journal of Analytical Chemistry, vol. 62, p. 2043-2048.

Thurman, E.M., Goolsby, D.A., Meyer, M.T., Mills,
M.S., Pomes, M.L., and Kolpin, D.W., 1992, A reconnaissance study of herbicides and their metabolites in surface water of the midwestern United States using immunoassay and gas chromatography/mass spectroscopy: Environmental Science and Technology 1992, vol. 26, no. 12, p. 2440-2447.

Thurman, E.M., Mills, M.S., and Meyer, M.T., in press, Chemistry, degradation, and transport of triazine herbicide metabolites in surface water, in Morganwalp, D.W. and Aronson, D.A., eds., U.S. Geological Survey Toxic Substances Hydrology Program-Proceedings of the Technical Meeting, Colorado Springs, Colorado, September 20-24, 1993: U.S. Geological Survey Water-Resources Investigations Report 94-4014.

Tomer, M.D., 1994, Describing soil and crop variability on a sand-plain landscape with surface-collected data; St. Paul, University of Minnesota, Ph.D. dissertation, $175 \mathrm{p}$.

U.S. Department of Agriculture Soil Conservation Service, 1992, Soil Survey Laboratory Methods Manual: Soil Service Investigations Report, no. 42, $400 \mathrm{p}$.

U.S. Department of Commerce, 1961-92, Minnesota annual summary reports: National Oceanic and Atmospheric Administration.

U.S. Environmental Protection Agency, 1983, Methods for Chemical Analysis of Water and Wastes: U.S. EPA Report 600/4-79-020, Cincinnati, Ohio.

U.S. Environmental Protection Agency, 1991, National primary drinking water regulations- Synthetic organic chemicals and inorganic chemicals; Monitoring for unregulated contaminants: National Primary Drinking Water Regulations Implementation; National Secondary DrinkingWater Regulations (1/30/91): Federal Register, vol. 56 , no. 2, p. 3526-3597.

Weeks, E.P., 1969, Determining the ratio of horizontal to vertical permeability by aquifer-test analysis: Water Resources Research, vol. 5, no. 1, p. 196-214.

Winkelman, D.A., and Klaine, S.J., 1990, Degradation and bound residue formation of atrazine in a western Tennessee soil: Environmental Toxicology and Chemistry, vol. 10, no. 3, p. 335-345.

Woodward, D.G., 1986, Hydrogeologic framework and properties of regional aquifers in the Hollandale Embayment, southeastern Minnesota: U.S. Geological Survey Hydrologic Investigations Atlas HA-677, 2 plates. 
Wright, H.E., 1972a, Quaternary history of Minnesota, in Sims, P.K., and Morey, G.B., eds., Geology of Minnesota-A centennial volume: Minnesota Geological Survey, p. 515-546.

1972b, Physiography of Minnesota, in Sims, P.K., and Morey, G.B., eds., Geology of

Minnesota-A centennial volume: Minnesota Geological Survey, p. 561-578.

Wright, H.E., Jr., and Ruhe, R.V., 1965, Glaciation of Minnesota and Iowa, in Wright, H.E., Jr., and Frey, D.G., eds.: The Quaternary of the United States: Princeton, N.J., Princeton University Press., p. 2941.

Wright, Jerry, and Bergsrud, Fred, 1991, Irrigation scheduling - checkbook method: University of Minnesota Extension Service Bulletin AG-FO1322-C, 12 p.

Zapico, M.M., Vales, Samuel, and Cherry, J.A., 1987, A wireline piston core barrel for sampling cohesionless sand and gravel below the water table: Ground Water Monitoring Review, vol. VII, no. 3, p. 74-82. 